\title{
STABLE RIPRAP SIZE FOR OPEN CHANNEL FLOWS
}

\author{
by \\ Stephen T. Maynord \\ Hydraulics Laboratory \\ DEPARTMENT OF THE ARMY \\ Waterways Experiment Station, Corps of Engineers \\ PO Box 631, Vicksburg, Mississippi 39180-0631
}
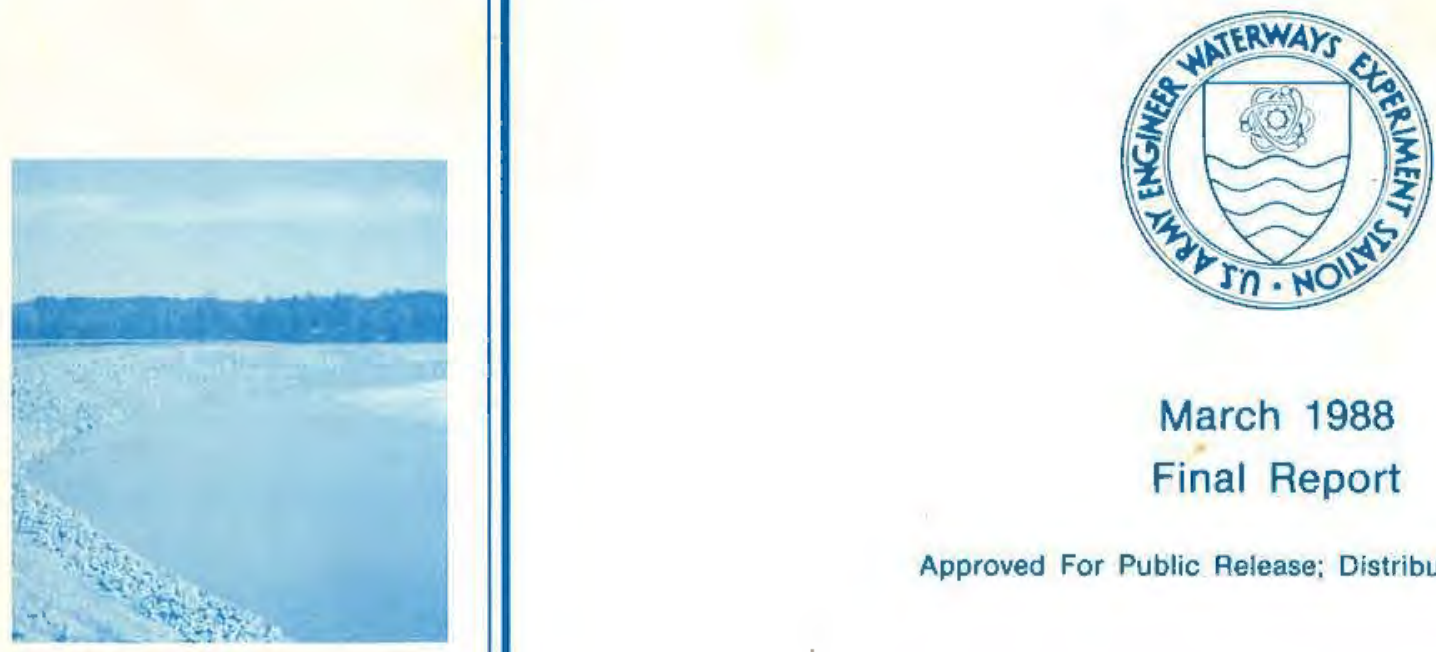

March 1988

Final Report

Approved For Public Release; Distribution Unlimited

Prepared for DEPARTMENT OF THE ARMY

US Army Corps of Engineers

Washington, DC 20314-1000

Under CWI Work Unit No. 31028 
Destroy this report when no longer needed. Do not return it to the originator.

The findings in this report are not to be construed as an official Department of the Army position unless so designated by other authorized documents.

The contents of this report are not to be used for advertising, publication, or promotional purposes. Citation of trade names does not constitute an afficial endorsement or approval of the use of such commercial products. 
Wnasanged SECURITY CLASSIFICATION OF YHIS PAGE

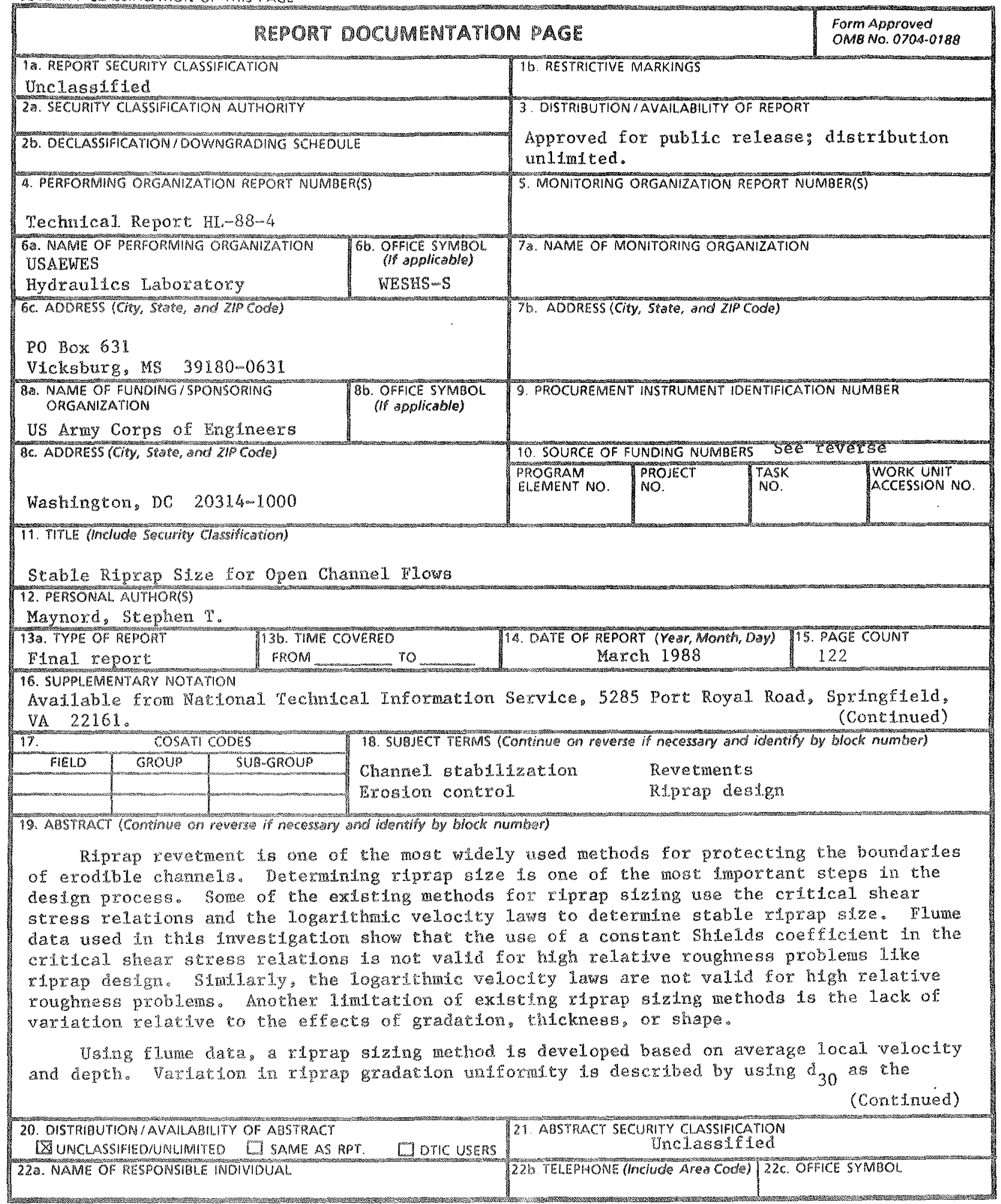

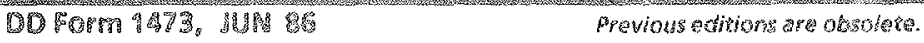

SECURIY CLASSIFICATION OF THIS PAGE

Unclassiffed 
10. WORK UNIT ACCESSION NO. (Continued).

Funding provided by Civil Works Research and Development Program under Civil Works Investigation Work Unit No. 31028, "Effects of Water Flow, on Riprap in Flood Channels," sponsored by Headquarters, US Army Corps of Engineers.

1.6. SUPPLEMENTARY NOTATION (Continued).

Origtnally submitted in partial fulfilment of the requirements for the degree of Doctor of Philosophy in Civil Engineering to Colorado State University, Fort Collins, Colorado.

19. ABSTRACT (Continued).

characteristic size. Thicker riprap blankets allow a reduction in size, and shape effects within the range tested are insignificant.

Existing side slope relations used in the crttical shear stress equation overestimate the decrease in stability that occurs when a particle is placed on a sloping bank. Conparison of velocity proftles over channel side slopes in straight and curved reaches shows that for the same average velocity over the roe of the side slope, the velocity and shear stress on the side slope are significantly higher on the outer bank of the curved channel. Depth and average velocity over the toe of the side slope are measured in straight and curved flume tests of riprap stability and are used to develop sizing relations for side slope riprap. Results are compared to fleld data, and safery factors are recommended. A stzing nomograph and an example destgn are presented. 
The study described herein was performed at the US Army Engineer Waterways Experiment Station (WES) during the period 1980-1986 for the Headquarters, US Army Corps of Engineers (USACE), as part of the Civil Works Research and Development Program. Funds were allotted under Civil Works Investigation Work Unit No. 31028, "Effects of Water Flow on Riprap in Flood Channels," under USACE Program Monitor Mr. Tom Munsey. This study was accomplished under the direction of Messrs. H. B. Simmons, former Chief of the Hydraulics Laboratory, F. A. Herrmann, Jr., Chief of the Hydraulics Laboratory, J. L. Grace, Jr., former Chief of the Hydraulic Structures Division, and G. A. Pickering, Chief of the Hydraulic Structures Division. The WES tests were conducted by Messrs. S. T. Maynord, project engineer, E. L. Jefferson, and R. Bryant under the direct supervision of Mr. N. R. Oswalt, Chief of the Spillways and Channels Branch. This report was written by Dr. S. T. Maynord and edited by Mrs. Marsha Gay, Information Technology Laboratory.

This report was also submitted to the Academic Faculty of Colorado State University, Fort Collins, Colorado, in partial fulfillment of the requirements for the degree of Doctor of Philosophy in Civil Engineering.

COL Dwayne G. Lee, CE, is the Commander and Director of WES. Dr. Robert $W$. Whalin is the Technical Director. 


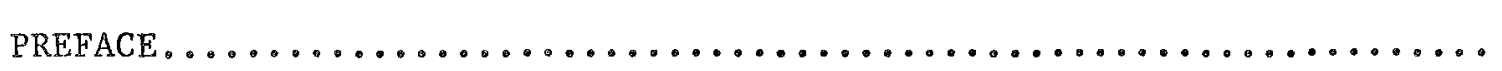

CONVERSTON FACTORS, NON-SI TO SI (METRIC)

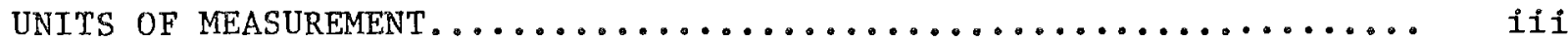

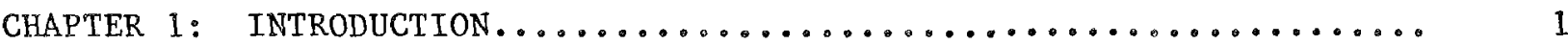

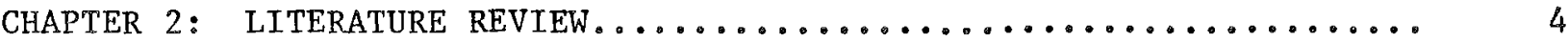

2.1 Applicability of Existing Riprap Sizing Methods That Use a Constant Shields Coefficient or the Logarithmic

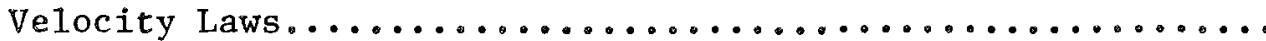

2.2. Existing Critical Velocity Methods for Particle

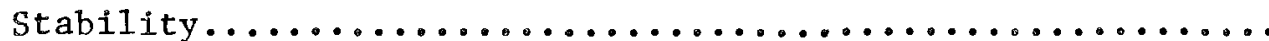

2.3 Previous Studies on the Effects of Gradation, Thickness,

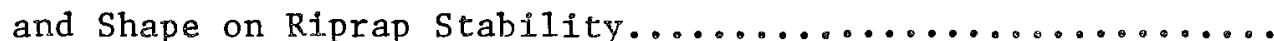

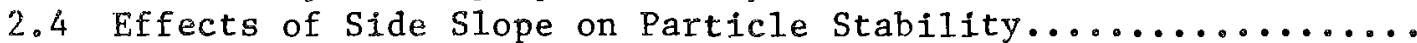

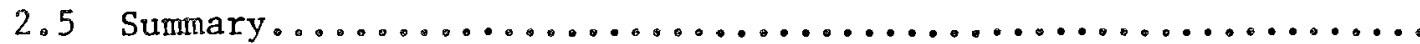

CHAPTER 3: EXPERIMENTAL INVESTIGATION.................... 19

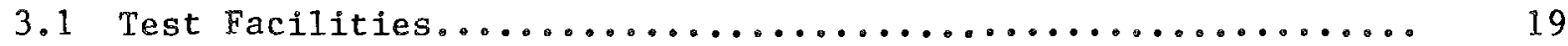

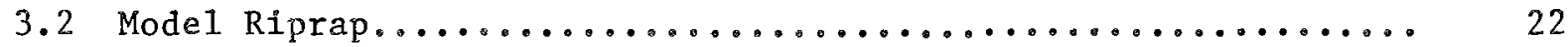

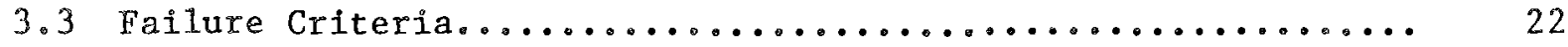

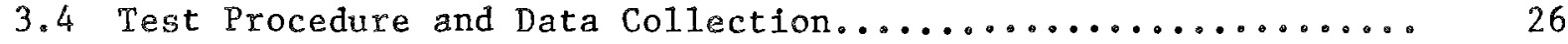

3.5 Data Restrictions............................. 27

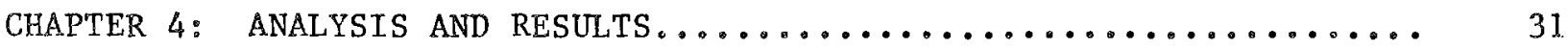

4.1 Applicability of Existing Sizing Relations Using a Constant Shields Coefficient or Logarithmic Velocity

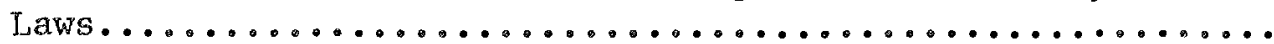

4.2 Development of Crjtical Velocity Relation.................

4.3 Effects of Gradation, Thickness, and Shape

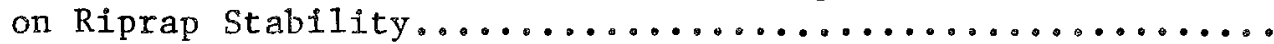

4.4 Effects of Side Slope on Riprap Stability.............. 48

CHAPTER 5: SAFETY FACTORS, SIZING NOMOGRAPH, AND DESIGN

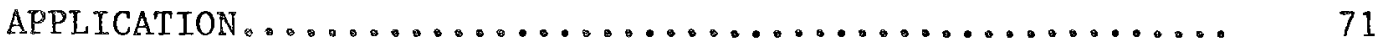

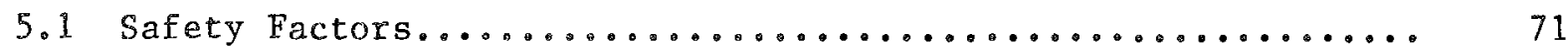

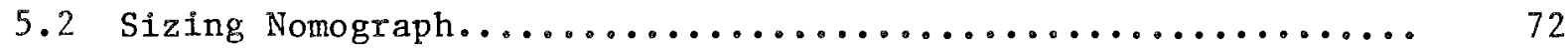

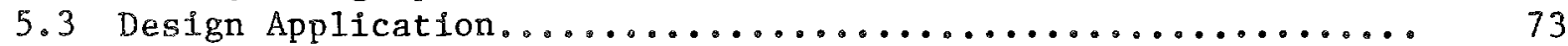

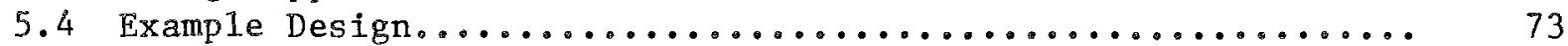

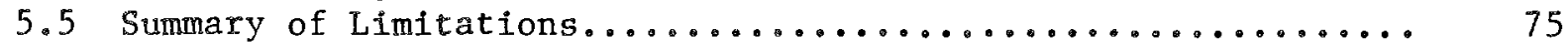

CHAPTER 6: CONCLUSIONS AND RECOMMENDATIONS.................. 76

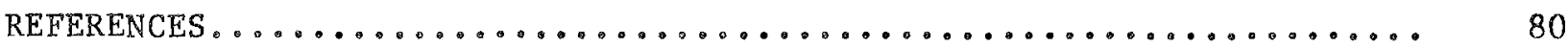

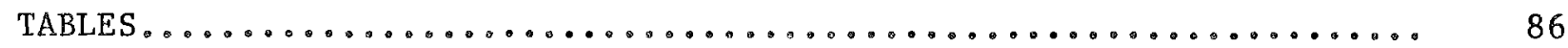

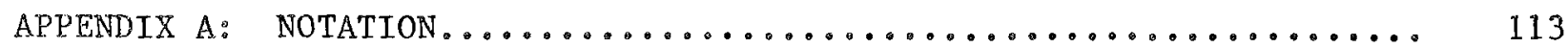


Non-SI units of measurement used in this report can be converted to SI (metric) units as follows:

Multiply

cubic feet

degrees (angle)

feet

inches

pounds (mass)

pounds (mass)

per cubic foot

square feet
By

0.02831685

0.01745329

0.3048

2.54

0.4535924

16.01846

0.09290304
To Obtain cubic metres radians

metres

centimetres

kilograms

kilograms per cubic metre square metres 


\section{STABLE RIPRAP SIZE FOR OPEN CHANNEL FLOWS}

\section{CHAPTER 1}

\section{INTRODUCTION}

The transport of water through natural and man-made open channels carries the possibility of scour if the channel boundaries are erodible. While many different methods have been used to protect channel boundaries, riprap revetment continues to be one of the most widely used methods. Riprap is long-lasting, flexible, easily placed and repaired, and natural in appearance. However, in some locations riprap is not readily avallable or the available stone is too small for riprap. In other locations, a limited number of available gradations, rather than design guidance, determines the size used. Transportation costs for riprap from quarry to jobsite are often greater than the cost of the rock alone. In spite of these 11mitations, the large amount of riprap used requires guidance to ensure optimum design.

Determining riprap size is one of the most important factors in defining the optimum riprap gradation. Existing riprap sizing methods have limitations which include the following:

1. Many existing riprap sizing methods have evolved from sediment transport concepts which use shear stress to define particle stability. Critical shear stress for a given riprap size is determined by the well-known Shields coefifients. Most sediment transport and riprap sizing techniques use a constant Shields coefficient for rough turbulent flow. Existing riprap design techniques also use logarithmic velocity laws to relate 
velocity to shear stress. However, several investigators have found the Shields coefficient to vary at high relative roughness while others have found the logarithmic velocity laws to be affected by high relative roughness. Since most riprap stability problems involve high relative roughness, many of the existing riprap sizing methods may not be applicable.

2. Existing riprap sizing methods that use shear stress have an additiona1 1iability. As stated by Neill and Hey (1982), Researchers tend to favor shear stress criteria for stability and bed movement. From a practical engineering viewpoint, local shear stresses are difficult to measure and to conceptualize, compared to velocities. Researchers might pay more attention to expressing results in velocity terms for practical applications.

3. Existing riprap sizing methods also lack variation relative to the effects of riprap gradation, thickness, and shape.

4. The analytical techniques used to determine the decrease in stability that results from placing riprap on a channel side slope need to be tested against experimental data.

Considering these limitations of existing riprap sizing methods, the objectives of this study are as follows:

1. Evaluate the applicability of existing riprap sizing methods that use a constant Shields coefficient or the logarithmic velocity laws.

2. Develop a riprap method based on velocity. Determine which velocity (bottom, average, surface, or maximum) to use in the riprap sizing method.

3. Incorporate riprap gradation, thickness, and shape variation into riprap sizing method. 
4. Evaluate side slope effects on riprap stablilty and incorporate into riprap sizing method for straight and curved channels.

A series of flume tests were used to accomplish these objectives by studying the stability and resistance to flow of riprap having gradation, thickness, and shape similar to that used for scour protection in open channels. Results are limited to channels with slopes less than 2 percent, and the ratio of flow depth to average riprap size must be greater than 4. Riprap sizing for placement in highly turbulent flow downstream of hydraulic structures or for placement on embankments subject to overtopping flows is not covered in this study. The following chapters present first a review of existing literature relative to these four objectives. Next, the experimental investigation is explained, and then the analysis and results to achieve each of these four objectives are presented. Finally the conclusions from the study and recommendations for further studies are presented. 


\section{CHAPTER 2}

\section{LITERATURE REVIEW}

In the study of open channel riprap stability, many investigations have been conducted that are applicable to this engineering problem. This review of existing information focuses on four different topics which correspond to the four objectives in the Introduction. First, studies concerning the effects of relative roughness on shields coefficient and logarithmic velocity equations will be reviewed to see if existing sizing techniques are valid. Second, the literature will be searched for existing riprap sizing methods based on velocity. Third, previous studies will be reviewed to determine the present knowledge regarding the effects of thickness, shape, and gradation on particle stability. Fourth, existing concepts of side slope particle stability will be reviewed and summarized.

\subsection{APPLTCABILITY OF EXISTING RIPRAP SIZING METHODS USING A CONSTANT SHIELDS COEFFTCIENT OR THE LOGARITHMIC VELOCITY LAWS}

One of the most common methods for evaluating riprap stability is the critical shear stress nethod (also called tractive force). The shear stress stability concept was used by Dubuat (1786) but did not become popular until Schoklitsch (1914). Lane (1953) used the tractive force method for stable canal design in noncohesive material. Anderson, Paintal, and Davenport (1968) developed the tractive force approach into a riprap design method which includes the effects of side slopes and 
channel bends. The work of Anderson, Paintal, and Davenport is used as the basis for riprap design by the US Department of Transportation (1975). The Office, Chief of Engineers (OCE), (1970 and 1971) riprap design guidance is based on the tractive force approach. Li et a 1 . (1976) and Stevens and Simons (1971) developed tractive force methods which incorporate probability and safety factors into the design method. The shear stress exerted on the boundary in uniform flow is

$$
T=\gamma_{W} D S
$$

where

$$
\begin{aligned}
T & =\text { tractive force imposed by flowing water }{ }^{1} \\
\gamma_{W} & =\text { specific weight of water } \\
D & =\text { flow depth } \\
S & =\text { energy slope }
\end{aligned}
$$

or using hydraulic radius

$$
\Upsilon \approx \gamma_{W} R S
$$

where $R$ is the hydraulic radius.

The imposed force calculated from either Equation 2.1 or 2.2 is equated to the ability of the particle to resist movement or the critical shear stress. Using the analysis of Carter, Carlson, and Lane (1953), which is an equilibrium force analysis, yields

$$
\mathrm{T}_{\mathrm{c}}=\mathrm{C}_{1}\left(\gamma_{\mathrm{s}}-\gamma_{\mathrm{w}}\right) \mathrm{d} \tan \Phi
$$

where

$$
T_{c}=\text { critical tractive force for given particle size on bottom }
$$

${ }^{1}$ For convenience, symbols and unusual abbreviations are listed and defined in the Notation (Appendix A). 


$$
\begin{aligned}
C_{1} & =\text { coefficient } \\
\gamma_{S} & =\text { specific weight of stone } \\
d & =\text { particle size } \\
\Phi & =\text { angle of repose }
\end{aligned}
$$

Formulations of the shear relations from dimensional analysis depend on which parameters are considered significant. Vanoni (1977) uses the parameters $T_{c}, \gamma_{s}-\gamma_{w}, d$, the fluid density $\rho$, and viscosity $v$, to define incipient motion. This results in the same form derived by Shields (1936) or

$$
\frac{T_{c}}{\left(\gamma_{s}-\gamma_{w}\right)^{d}}=f\left(\frac{U_{*} d}{v}\right)
$$

where

$$
\begin{aligned}
U_{*} & =\text { shear velocity }=\sqrt{\text { gDS }} \\
g & =\text { universal gravitational constant }
\end{aligned}
$$

For rough turbulent flow (particle Reynolds number $\frac{U_{*} d}{v}>400$ ), the right side is often assumed constant and called the Shields number or Shields coefficient, herein denoted as $C_{c}$. Most of the stability investigations concerning Shields coefficient have been related to sediment transport. According to Graf (1971), the definition of the cxitical Shields coefficient has been subject to the interpretation of the researcher. The riprap design procedures by OCE (1970) and Anderson, Paintal, and Davenport (1968) use a constant Shields coefficient for safe design.

The use of a constant Shields coefficlent has been questioned by Meyer-Peter and Mullex (1948), Yalin (1965), Barr and Herbertson (1966), Blench (1966), Neil1 (1967 and 1968), Bogardi (1968), Ashida and Bayazit 
(1973), Bathurst, Graf, and Cao (1982), Daido (1983), and Bettess (1984), who propose that Shields coefficients should vary with relative roughness. Bathurst, Graf, and Cao (1982) and Bettess (1984) have found this variation with relative roughness to be limited to high relative roughness below which Shields coefficient becomes constant. Meyer-Peter and Muller (1948) found that the limiting shear stress is proportional to particle diameter and relative roughness and proposed an equation

$$
C_{c}=C_{2}\left(\frac{d}{R}\right)^{1 / 9}
$$

An explanation for a changing Shields coefficient with relative roughness has been offered by Escoffier (1968). At high relative roughness (low depth $/ d_{50}$ ), turbulence generated at the boundary is hindered by the presence of the free surface. Consequently the fluctuations in velocity are decreased. At low relative roughness (large depth/ $\mathrm{d}_{50}$ ), the boundary-generated turbulence is not hindered by the free surface and fluctuations in velocity are not reduced. Since the magnitude of turbulent fluctuations is critical for riprap stability, this provides an explanation for the variation of Shields coefficient with relative roughness. Chen and Roberson (1974) and Bayazit (1976) found that measured turbulence intensity decreased with increase of relative roughness in the region near the wall. Bayazit (1982) proposed that this "can be explained by the fact that a substantial part of the energy of the mean flow is converted into turbulence in the separation zones between the roughness elements in the case of large scale roughness." Gessler (1971) stated that relative roughness does not influence Shields coefficient because incipient conditions depend only on conditions at the bed and not on the boundary layer thickness (or depth in open channels). 
Some of the existing riprap procedures (OCE 1970 and Li et a1. 1976) use the logarithmic velocity laws to determine the relation between velocity and shear stress on the boundary. The universal velocity distribution law for rough surfaces is

$$
\frac{v_{y}}{U_{*}}=\frac{2.3}{k} \log \frac{30\left(y+y_{o}\right)}{K_{s}}
$$

where

$$
\begin{aligned}
V_{y} & =\text { local velocity at distance } y \\
\mathrm{x} & =\text { von Karman coefficient } \\
\mathrm{y} & =\text { distance above origin } \\
\mathrm{y}_{\mathrm{o}} & =\text { distance below top of roughness element to origin of profile } \\
\mathrm{K}_{\mathrm{s}} & =\text { equivalent sand grain roughness }
\end{aligned}
$$

Equation 2.6 is integrated over the depth to determine the mean velocity relations (Keulegan 1938). For wide channels, with essentially twodimensional flow, the mean velocity relation is

$$
\frac{\mathrm{V}}{\mathrm{U}_{*}}=\frac{2.3}{\mathrm{~K}} \log \frac{11.1 \mathrm{D}}{\mathrm{K}_{\mathrm{S}}}
$$

where $V$ is the average flow velocity.

Several difficulties arise in application of the logarithmic velocity laws to rough surfaces.

1. Origin for Velocity Profile. Several investigators, including Einstein and E1-Samni (1949), O'Lough1in and McDonald (1964), Knight and McDonald (1979), Bayazit (1982), and Coleman, Hodge, and Taylor (1984), have shown that the velocity profile origin for rough surfaces lies below the tops of the roughness elements. There is no general agreement as to the location of the origin. The relation between veloctty and tractive force is 
sensitive to the origin location, particularly at high relative roughness.

2. $\mathrm{K}_{\mathrm{s}}$ Value. Previous studies have used $\mathrm{K}_{\mathrm{s}}$ values ranging from $d_{50}$ (OCE 1970) to $3.5 d_{84}$ (Hey 1979). Particle sizes $d_{50}$, $\mathrm{d}_{84}$, etc., refer to the size of which a given percentage is finer by weight. Kamphius (1974) found $\mathrm{K}_{S}=2 \mathrm{~d}_{90}$ for depth/ $\mathrm{d}_{90}>10$. Van Rijn (1982) determined an average value of $\mathrm{K}_{\mathrm{S}}=3 \mathrm{~d}_{90}{ }^{\circ}$

3. Effects of Relative Roughness. Yalin (1977) has shown that Equation 2.6 is not valid at relative depth $\mathrm{D} / \mathrm{d}_{90}$ less than approximately 10 because $\mathrm{K}_{\mathrm{s}} / \mathrm{d}_{90}$ varies below $\mathrm{D} / \mathrm{d}_{90}=10$. other investigators have also suggested limiting application of the logarithmic velocity equations to small scale roughness. Bathurst, Graf, and Cao (1982) give $\mathrm{D} / \mathrm{d}_{84}>6$ for sma11-scale roughness. Van Rijn (1982) places the strictest requirement by limiting application of the logarithmic velocity laws to $\mathrm{D} / \mathrm{K}_{\mathrm{S}}>10$. Van Rijn (1982) found $\mathrm{K}_{\mathrm{S}}=3 \mathrm{~d}_{90}$ which implies a limitation $\mathrm{D} / \mathrm{d}_{90}>30$ on the logarithmic laws.

4. Von Karman $k$. There has been considerable disagreement over the von Karman $\kappa$ and its constancy in clear versus sedimentladen flow. Coleman (1981) found that by evaluating $k$ in the lower 15 percent of the flow, $K$ was the commonly used 0.4 for clear or sediment-laden flow. However for high relative roughness $\mathrm{D} / \mathrm{d}=4.0$ and 8.5 , Bayazit (1982) found $K<0.4$ for clear water flow in the region near the bed. Iram (1981) found von Karman's $k$ both higher and lower than 0.4 depending on the nature of the roughness. 
Sunnarizing, other investigators have suggested that a constant Shields coefficient and the logarithmic velocity laws should not be used for problems involving high relative roughness.

2.2 EXISTING CRITICAL VELOCITY METHODS

FOR PARTICLE STABILITY

Some of the earliest stability relations used particle size or weight as a function of velocity. Graf (1971) presented the general relation

$$
\frac{v_{b}^{2}}{\left(\frac{\rho}{\rho}-1\right) g d}=\frac{2 K_{3}(\tan \Phi \cos \alpha-\sin \alpha)}{C_{d} K_{1}+C_{\ell} K_{2} \tan \Phi}
$$

where

$$
\begin{aligned}
V_{b} & =\text { botcom velocity } \\
\rho_{s} & =\text { stone density } \\
\mathrm{K}_{1}, \mathrm{~K}_{2}, \mathrm{~K}_{3} & =\text { coefficlents } \\
\alpha & =\text { bottom angle with horizontal in flow direction } \\
\mathrm{C}_{\mathrm{d}} & =\text { drag coefficient } \\
\mathrm{C}_{\ell} & =1 \text { ift coefficient }
\end{aligned}
$$

Graf referred to the right side of Equation 2.8 as the sediment coefficient which varies with particle characteristics (shape, size, uniformity, texture, repose angle) and flow characteristics.

Forchheimer (1914) reported that as early as 1753, A. Brahms presented the relation

$$
v_{b}=c_{3} w^{1 / 6}
$$

where $W$ is the unsubmerged stone welght. Equation 2.9 is a simple form of Equation 2.8. Isbash (1935) related stone size for dam closures to a bottom velocity called the "velocity against the stone." 
Equation 2.8 is the form used by Isbash and serves as the basis for Hydraulic Design Criteria (HDC) Sheet 712-1 (US Army Corps of Engineers): Average velocity is used in HDC 712-1 instead of bottom velocity, which may cause these curves to be rather conservative for low turbulence flows. The National Crushed Stone Association (1978) presents guidance for sizing riprap based on average velocity. The California Division of Highways (1970) uses a design equation having the same form as Equation 2.8.

B1odgett and McConaughy (1986) proposed the following relation for stable rock size based on extensive prototype data

$$
\mathrm{d}_{50}=0.01 \mathrm{~V}_{\mathrm{a}}^{2.44}
$$

where $V_{a}$ is the cross-section average channel velocity. Adjustments for bank angle, unit stone weight, channel shape, etc., are not used in this design procedure.

Critical velocity relations using average velocity and depth are also used for particle stability. They have been rewritten in a common form to assist in their comparison. Straub (1953) presented the average velocity and depth relation

$$
\frac{d}{\bar{D}}=0.31\left[\left(\frac{\gamma_{W}}{\gamma_{s}-\gamma_{w}}\right)^{1 / 2} \frac{V}{\sqrt{g D}}\right]^{3}
$$

Nei11 (1967) used dimensional analysis to determine the pertinent relationships for stability of coarse, uniform bed material and conducted scour tests using the incipient criterion of first movenent by visual observation. His conservative design curve is represented by the equation 


$$
\frac{\mathrm{d}}{\mathrm{D}}=0.32\left[\left(\frac{\gamma_{\mathrm{w}}}{\gamma_{\mathrm{s}}-\gamma_{\mathrm{w}}}\right)^{1 / 2} \frac{\mathrm{v}}{\sqrt{\mathrm{gD}}}\right]^{2.5}
$$

Nei11 and Van Der Giessen (1966) suggested that relative roughness, which results from the dimensional analysis, is connected with the Intensity of turbulent fluctuation. Nei11 (1968) stated that because the flume size and rest section area were constant, the first movement criterion was more severe for the smaljer particles and Equation 2.12 may not be valid. Because the test section contained smaller particles, and therefore more particles, a greacer probability of movement exists. Neill (1968) also stated that the equation is applicable to problems such as riprap stabillty. Bogardi (1968) presented particle stability data covering a wide range of $d / D$ and determined the relation

$$
\frac{d}{\bar{D}}=0.26\left[\left(\frac{\gamma_{\mathrm{w}}}{\gamma_{\mathrm{S}}-\gamma_{\mathrm{W}}}\right)^{1 / 2} \frac{\mathrm{v}}{\sqrt{\mathrm{gD}}}\right]^{2.47}
$$

which is almost identical to Neill (1967). Cooper (1970) analyzed sediment transport data for low rates of transport (concentration = 1 part per milion) and found good agxeement with Nel11's (1967) relation. Grace, Calhoun, and Brown (1973), Maynord (1978), and Reese (1984) used the riprap stability relation

$$
\frac{d_{50}}{D}=c_{4}\left[\left(\frac{\gamma_{W J}}{\gamma_{S}-\gamma_{W}}\right)^{1 / 2} \frac{\mathrm{V}}{\sqrt{g D}}\right]^{3}
$$

which is identical to straub (1953).

Combining and rearranging Equations 2.4 and 2.7 results in the $O C E$ (1970) procedure for riprap design using average velocity and depth: 


$$
d_{50}=\frac{\gamma_{w} v^{2}}{c_{c}\left(\gamma_{s}-\gamma_{w}\right)\left(32.6 \log \frac{11.1 D}{d_{50}}\right)^{2}}
$$

With the appropriate coefficients, Equations 2.14 and 2.15 give similar results over a wide range of d/D. Reese (1984) demonstrated that these two relations differ only by the velocity profile used. Equation 2.14 is based on a power velocity profile while Equation 2.15 is based on a logarthmic velocity profile.

Determining which velocity to use is an important step in developing a riprap sizing method based on velocity. Some form of bottom velocity is the most representative because it is closest to the bed. However bottom velocities are difficult to predict and measure (Bogardi 1978) because the velocity near the bottom varies rapldly with distance from the bed. Surface velocities axe easy to measure but difficult to predict and are not representative because they are far removed from the bed. Bogardi (1978) recommended the use of mean velocity in critical velocity relations. Mean velocity is the easiest to calculate using both numerical and physical modeling techniques.

\subsection{PREVIOUS STUDIES ON THE EFFECTS OF GRADATION, THICKNESS, AND SHAPE ON RIPRAP STABIIITY}

The effects of gradation on particle stability or resistance are generally accounted for by determining a characteristic size which represents any gradation. In the case of resistance, the larger size fractions are generally used for the characteristic size (van Rijn 1982 , Bayazit 1982). In the case of stablity, the characteristic size is found to vary. Einstein (1942) found $d_{35}$ to be the effective size for movement of sand mixtures. Schoklitsch (1962) used $d_{40}$ in stability 
relations. The California Division of Highways (1970) used $W_{33}$ fn the riprap sizing relation. Peterka (1958) used $\mathrm{a}_{40}$ in the riprap sizing relation for placement downstream of stilling basins. Shen and Lu (1983) found $\mathrm{d}_{30}$ to be the characteristic slze of nonunform surface material on an armored bed. Shen and Lu suggested that increased turbu Ience caused by the larger particles decreases the stability of nonunfform materials. Anderson, Paintal, and Davenport (1968) conducted Flume tests showing that nonuniform xipraps are less stable than unfform ripraps having the same average size. These results show that the characteristic size is less than the average size. Maynord compared the stability of vaxious riprap gradations and found that $d_{50}$ was the charactexistic size for riprap placed to a thickness of $1 \mathrm{~d}_{100}$. However, these tests differed fxom prototype placement of riprap because the careful placement techniques used in the model prevented segregation of sizes with the nonunfom ripraps. Many riprap sizing relations have used $d_{50}$ as the charactexistic size (OCE 1970, Anderson, Paintal, and Davenport 1968, US Department of Transpoxtation 1975, Blodgett and MeConaughy 1986)。

Standardized riprap gradations have been used by OCE (1971), California Dfvision of Highways (1970), and the US Army Engineer Division, Lower Mississippi Valley (1982). Simons and Senturk (1977) and the US Department of Transportation (1975) present a single curve defining riprap gradation.

Studies were not found on the effects of varying blanket thickness on ripxap stability. Present oce (1971) guidance requires a thickness of $1 \mathrm{~d}_{100}$ (maximum) or $1.5 \mathrm{~d}_{50}$ (maximum), whichever is larger, for placement in the dry. 
Shape effects on riprap stability are important in determining which shapes are acceptable. Neill (1968) compared the stability of spheres and "Irregular grains" and found no significant difference if the equivalent spherical diameter (volume basis) was adopted as the size of the irregular grains. Olivier (1967) conducted tests on overflow rock dams and found that rounded stone had to be approximately 15 percent larger than crushed stone for equivalent stability. This was attributed to surface smoothness, not shape. Present OCE (1970) guidance for riprap shape is as follows:

1. Stone predominantly angular

2. No more than 25 percent of stones having a stone length $\ell$ to stone thickness b ratio of $>2.5$

3. No stone having $\ell / b>3.0$

2.4 EFFECTS OF SIDE SLOPE ON

PARTICLE STABILITY

Since most riprap is placed on channel banks, the influence of side slope angle on riprap stability is important, Carter, Carlson, and Lane (1953) presented the effects of side slopes on particle stability by defining forces parallel and normal to the angle of repose of the material. The equilibrium condition given by Cartex, Carlson, and Lane is

$$
\tan \Phi=\frac{\sqrt{W_{S}^{2} \sin ^{2} \theta+a^{2} T_{S}^{2}}}{W_{S} \cos \theta}
$$

where

$$
\begin{aligned}
& W_{S}=\text { submerged weight of stone } \\
& \theta=\text { angle of side slope with horizontal } \\
& a=\text { effective area of particle }
\end{aligned}
$$


$T_{S}=$ critical tractive force for particle on side slope Carter, Carlson, and Lane defined the tractive force ratio $\mathrm{K}$ as the ratio of force on sloping side to that on level surface necessary to cause impending motion

$$
\mathrm{K}=\frac{\mathrm{T}_{\mathrm{S}}}{\mathrm{T}_{\mathrm{c}}}=\cos \theta \sqrt{1-\frac{\tan ^{2} \theta}{\tan ^{2} \Phi}}=\sqrt{1-\frac{\sin ^{2} \theta}{\sin ^{2} \Phi}}
$$

Equation 2.17 is used in many riprap design procedures including Anderson, Paintal, and Davenport (1968), US Department of Transportation (1975), and OCE $(1970,1971)$.

An alternate formulation by Graf (1971) includes lift force $\mathrm{F}_{\mathrm{L}}$ and the angle of inclination of the drag force or shear stress as a result of secondary motion $\beta$, which is especially pronounced in channel bends. The equilibrium condition is alternately written

$$
\tan \Phi=\frac{\sqrt{W_{s}^{2} \sin ^{2} \theta+2 a T_{s} W_{s} \sin \theta \sin \beta+a^{2} T_{s}^{2}}}{W_{s} \cos \theta-F_{L}}
$$

Lack of information on the angle $\beta$ has prevented evaluation of this form of the side slope stability analysis. Christensen (1972) developed a side slope stability analysis which included lift and showed that the relation given by Equation 2.17 is not conservative. Stevens and Simons (1971) determined the stability of coarse particles on a side slope based on equilibrium of moments instead of forces. Relative safery factors can be determined with this method and the authors concluded that the Carter, Carlson, and Lane (1953) method yields larger sizes than requixed by the stevens and simons method. 
No Investigations were found that test these side slope equations for open channel flow. There have been tests in the wave environment that test the applicability of the Hudson (1958) equation, which follows:

$$
W=\frac{\gamma_{s} H^{3}}{K_{D}\left(\frac{\gamma_{s}}{\gamma_{w}}-1\right)^{3} \cot \theta}
$$

where

$$
\begin{aligned}
H & =\text { wave height } \\
K_{D} & =\text { stability coefficient }
\end{aligned}
$$

Since wave forces act up and down the side slope, the effects of side slope angle are expected to be more severe than that in open channel flow where forces act along the slope. Comparing $1 \mathrm{~V}: 1.5 \mathrm{H}$ and $1 \mathrm{~V}: 3 \mathrm{H}$ side slopes in Hudson's equation gives the wave effect:

$$
\frac{\mathrm{d}(1 \mathrm{~V}: 1.5 \mathrm{H})}{\mathrm{d}(1 \mathrm{~V}: 3 \mathrm{H})}=1.26
$$

Using the open channel Equation 2.17 with. $\phi=40 \mathrm{deg}^{2}$ (OCE 1970) gives the velocity effect:

$$
\frac{\mathrm{d}(1 \mathrm{~V}: 1.5 \mathrm{H})}{\mathrm{d}(1 \mathrm{~V}: 3 \mathrm{H})}=1.71
$$

This comparison suggests that the tractive force relation (which has not been tested against stability data) overestimates the effects of side slope angle on stability.

\subsection{SUMMARY}

Several investigators have proposed that Shields coefficient should

${ }^{2}$ A table of factors for converting non-ST units of measurement to SI (metric) units is found on page iii. 
vary with relative roughness. Many of the existing riprap design techniques use a constant shields coefficient.

Past studies have shown that the logarithmic velocity laws should be Iimited to smallascale roughness. Present riprap guidance does not place any limitations on use of these laws. Other factors, including determining the correct values of $\mathrm{K}_{\mathrm{s}}, k$, and the profile origin, compound the difficulty in using these laws for surfaces having high relative roughness.

Severa1 different velocity-based riprap sizing methods have been developed. Average velocity is recomended for use in these equations. Previous studies on gradation effects on the stability of riprap have used a characterlstic size ranging from $d_{30}$ to $d_{50}$. No studies were found addressing the effects of riprap thickness on stability. Side slope stabllity equations have used equilibxium of both forces and moments. Information was not found in which these equations were tested against stability data. Comparison of the side slope equations for open channel flow with equations tested against wave data suggests that the existing side slope relations for open channel flow overestimate the effects of side slope angle. 
CHAPTER 3

EXPERIMENTAL INVESTIGATION

Experimental studies were conducted to determine the stability and resistance to flow of riprap having gradation, thickness, and shape similar to riprap used in the prototype installations. This chapter describes facilities, model riprap, failure criteria, test procedures and data collection, and data restrictions. Additional information on the Colorado State University (CSU) studies can be found in Fiuzat, Chen, and Simons (1982), Fluzat and Richardson (1983), Ruff et al. (1985), and Ruff et al. (1987).

\subsection{TEST FACILITIES}

One flume at CSU, Fort Collins, Colorado, and three flumes at the US Army Engineer Waterways Experiment Station (WES), V1.cksburg, Mississippi, were used to conduct the riprap tests. The CSU flume is $200 \mathrm{ft}$ long by $8 \mathrm{ft}$ whe by $4 \mathrm{ft}$ deep and can be tilted from 0 to 2 percent bottom slope. Maximum discharge is $100 \mathrm{cfs}$. The sides and bottom of the flume are made primarily of aluminum. A portion of the side of the flume is made of Plexiglas to allow observation of the test section. Two gates installed at the downstream end of the flume allow control of the water level in the flume under subcritical flow conditions. A motorized carriage can travel along the flume for carrying data collection instruments and photographic equipment. A schematic diagram of the flume and the test section is shown in Figure 3.1. The initial $100 \mathrm{ft}$ 


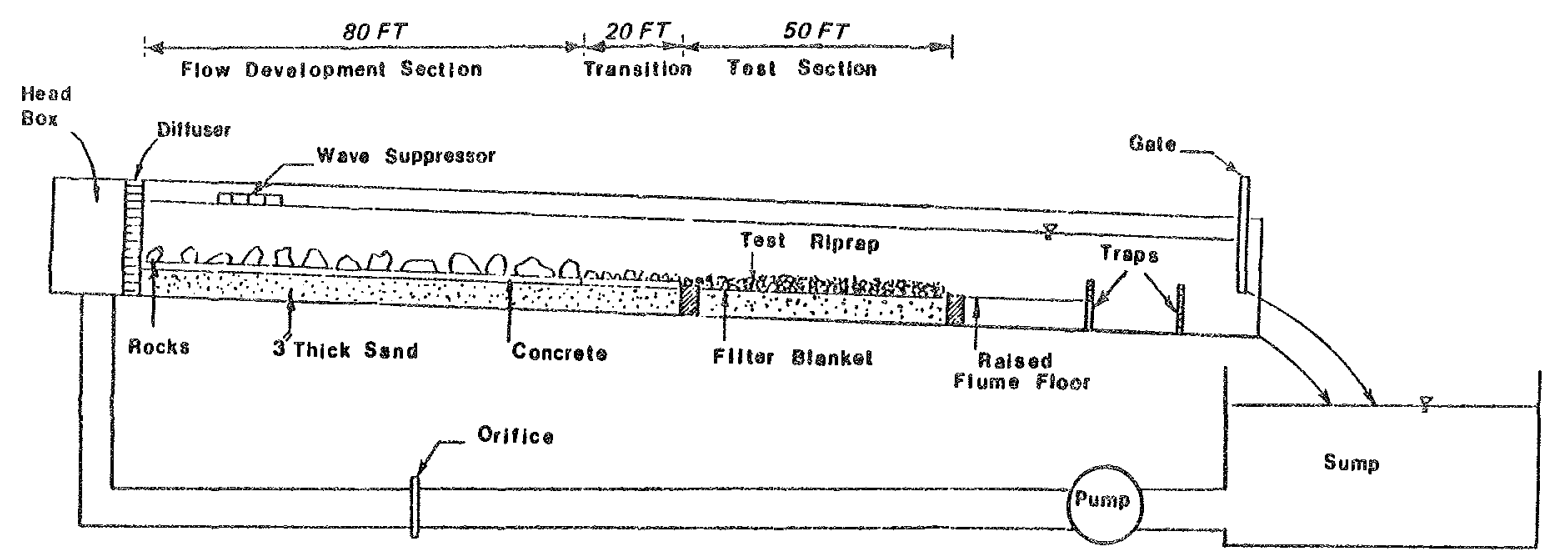

Figure 3.1. CSU tilting flume

of the flume was used for flow development and transition into the test section.

The csU tests consisted of four phases. Phases I-III addressed stability of bottom riprap having varying gradation, thickness, and shape. The Phase IV tests addressed stability of side slope riprap. In Phase I and II test series, large 6- to 10-in. rocks cemented to the flume floor between stations 0 and 80 produced a fully developed hydraulically rough boundary flow at the beginning of the 20-ft transition. Rock similar in size to that in the test section was placed in the 20-ft transition to eliminate the abrupt change in roughness between the flow development section and the test section. In the Phase III test series, the large 6- to 10 in. rocks were placed in the initial 60-70 ft of the flume. A 40w-ft-1ong transition was used in the Phase III tests. The rest section varied from 40 to $50 \mathrm{ft}$ in length for Phases I-III. Details of the Phase IV test Eacility, in which a $1 \mathrm{~V}: 2 \mathrm{H}$ side slope was tested, are shown in Figure 3.2 .

The wes trapezoidal channel model is described in Maynord (1978)。 This facility had a 5 -ft botton width with $1 \mathrm{~V}: 2 \mathrm{H}, 1 \mathrm{~V}: 3 \mathrm{H}$, and $1 \mathrm{~V}: 4 \mathrm{H}$ side slopes. Discharge capacity was $35 \mathrm{cfs}$, and a constant bottom slope of 
STATION

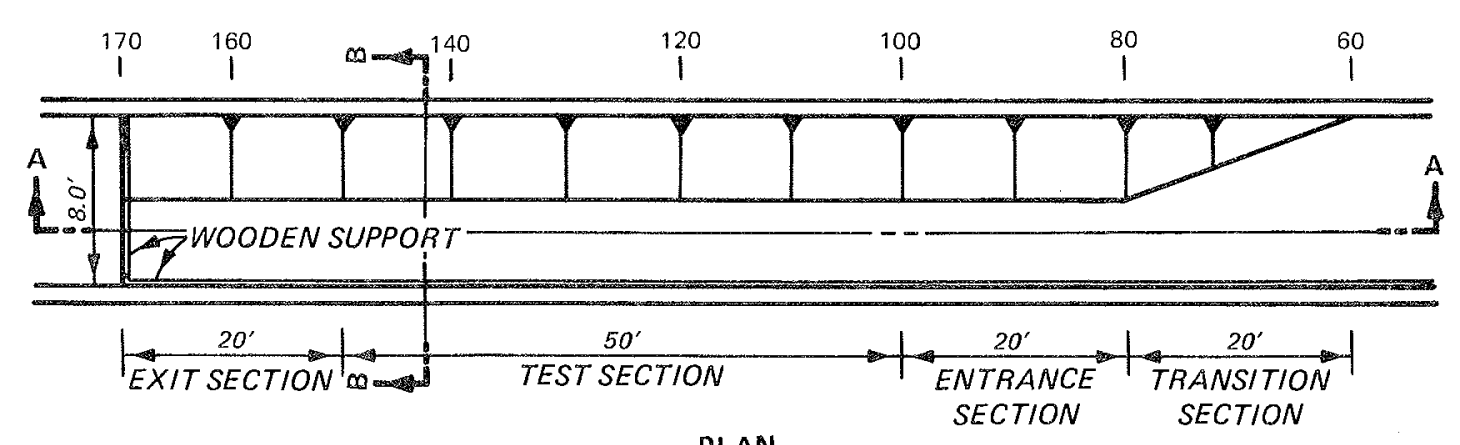

PLAN

if $\begin{aligned} & \text { WOODEN SUPPORT } \\ & \text { STAND }\end{aligned}$

SECTIONA-A

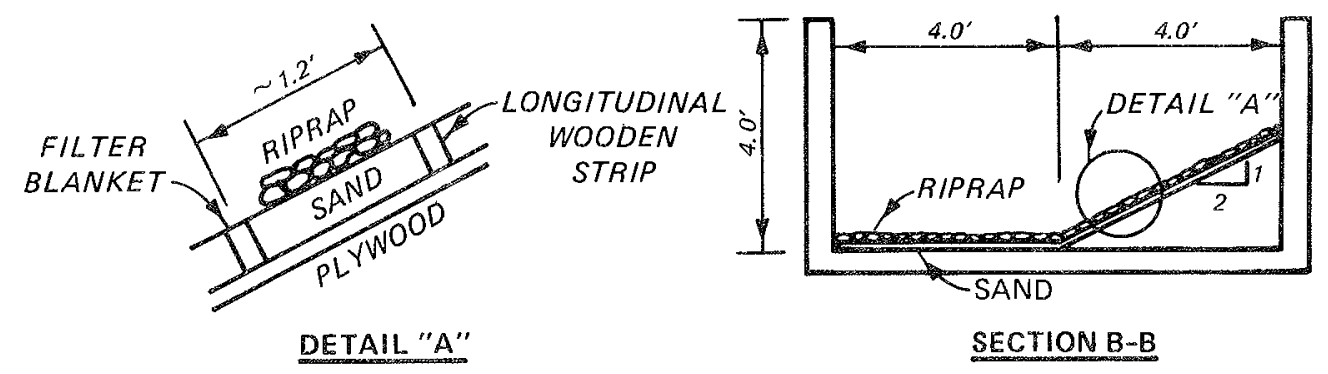

Figure 3.2. CSU Phase IV side slope test flume

$0.008 \mathrm{ft} / \mathrm{ft}$ was used in all tests. A tailgate was used to control depth of flow.

The WES tilting flume is $3 \mathrm{ft}$ wide by 1 ft deep by $75 \mathrm{ft}$ long. Maximum discharge is $5.6 \mathrm{cfs}$. Bottom slope can be varied from 0 to 2.2 percent, and a tailgate at the downstream end of the model is used to control depth of flow for subcritical flows. Steel rails set to grade are used to support instrumentation devices.

The WES curved channel model is shown in Figure 3.3. This trapezoidal channel has two $100 \mathrm{~m}$ deg bends with a centerline radius of $22 \mathrm{ft}$. The bends are separated by a 15-ft straight reach, and the straight reach on each end of the channel is $25 \mathrm{ft}$ in length. The bottom width is $7.0 \mathrm{ft}$, and side slopes are $1 \mathrm{~V}: 2 \mathrm{H}$. The bottom slope is $0.0025 \mathrm{ft} / \mathrm{ft}$, and the discharge varies up to 15 cfs. 


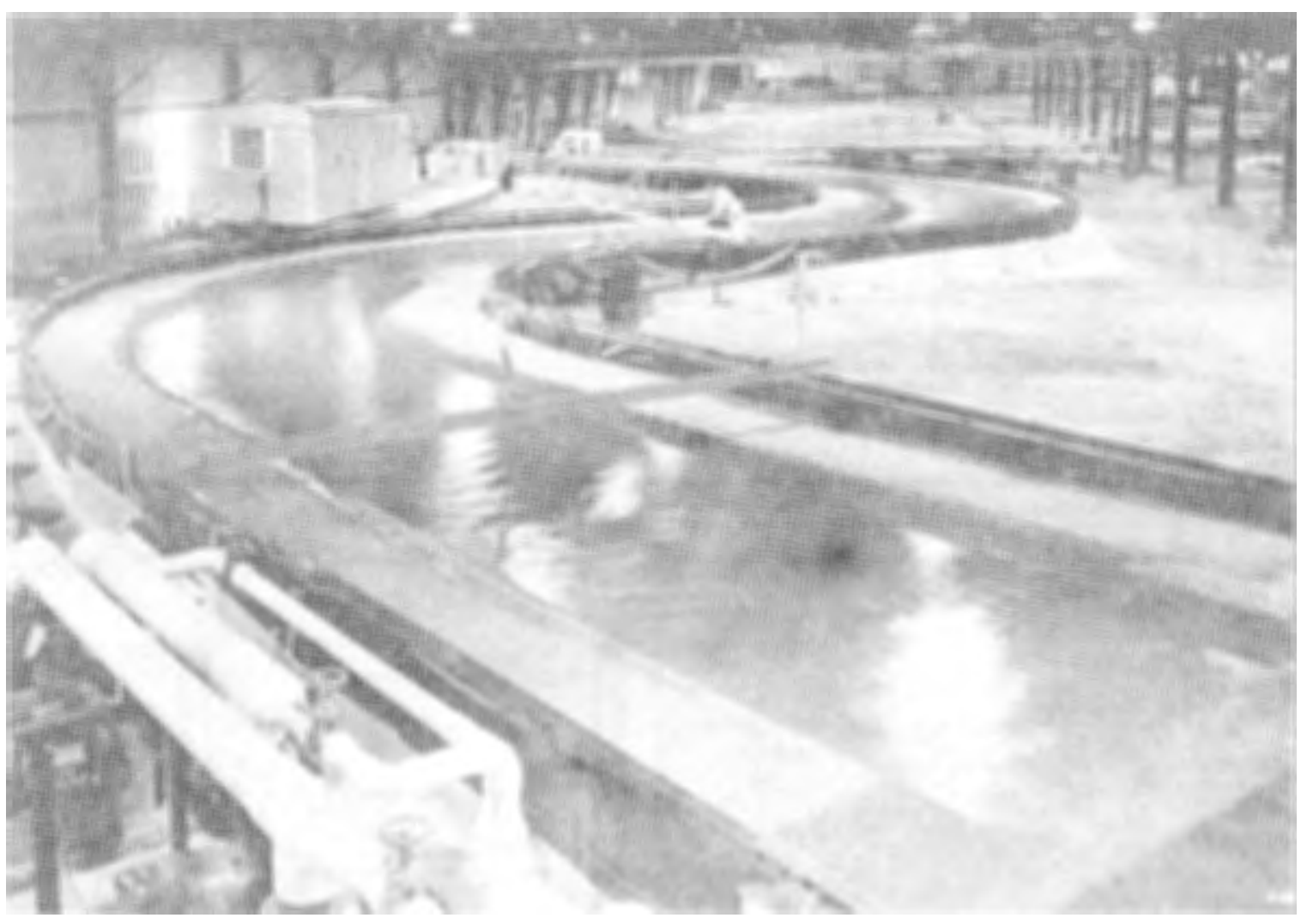

Figure 3.3. WES curved channel model.

\subsection{MODEL RIPRAP}

The characteristics of the model riprap used in these investiga tions are given in Table 3.1. Gradations for the CSU flume are shown in Figures $3.4-3.7$.

Al1 model riprap was crushed rock. Shape characteristics of the model riprap are shown in Table 3.2 .

\subsection{FAILURE CRITERIA}

At the outset of these experimental studies, an acceptable failure criterion had to be determined. The selected failure cxterion must be able to be used to determine riprap stability for a range of riprap gradation and blanket thicknesses. Most sediment transport studies using uniform materials have weighed the transported material for various flow rates and extrapolated the transport rate to zero to determine what is 


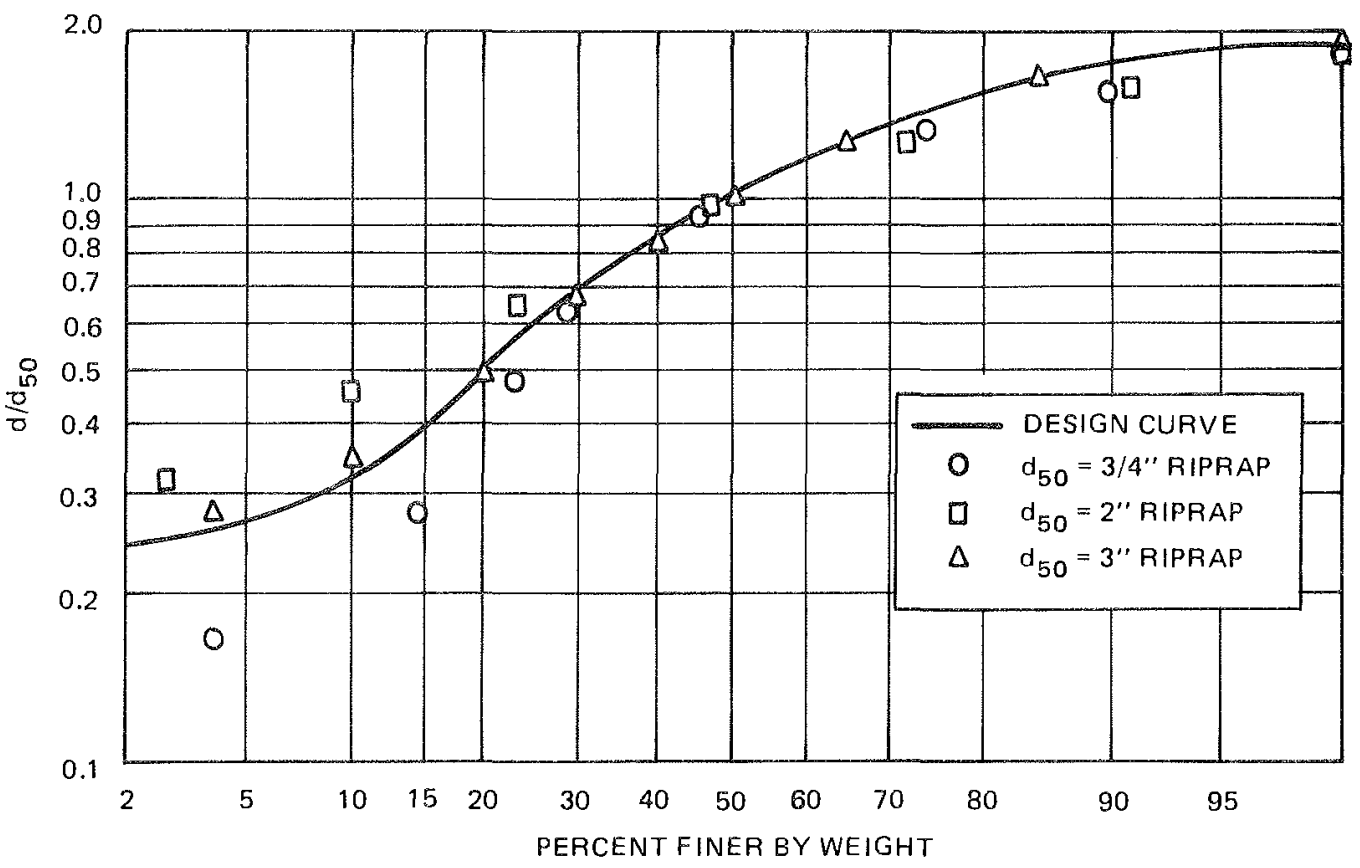

Figure 3.4. Size distribution for CSU Phase I

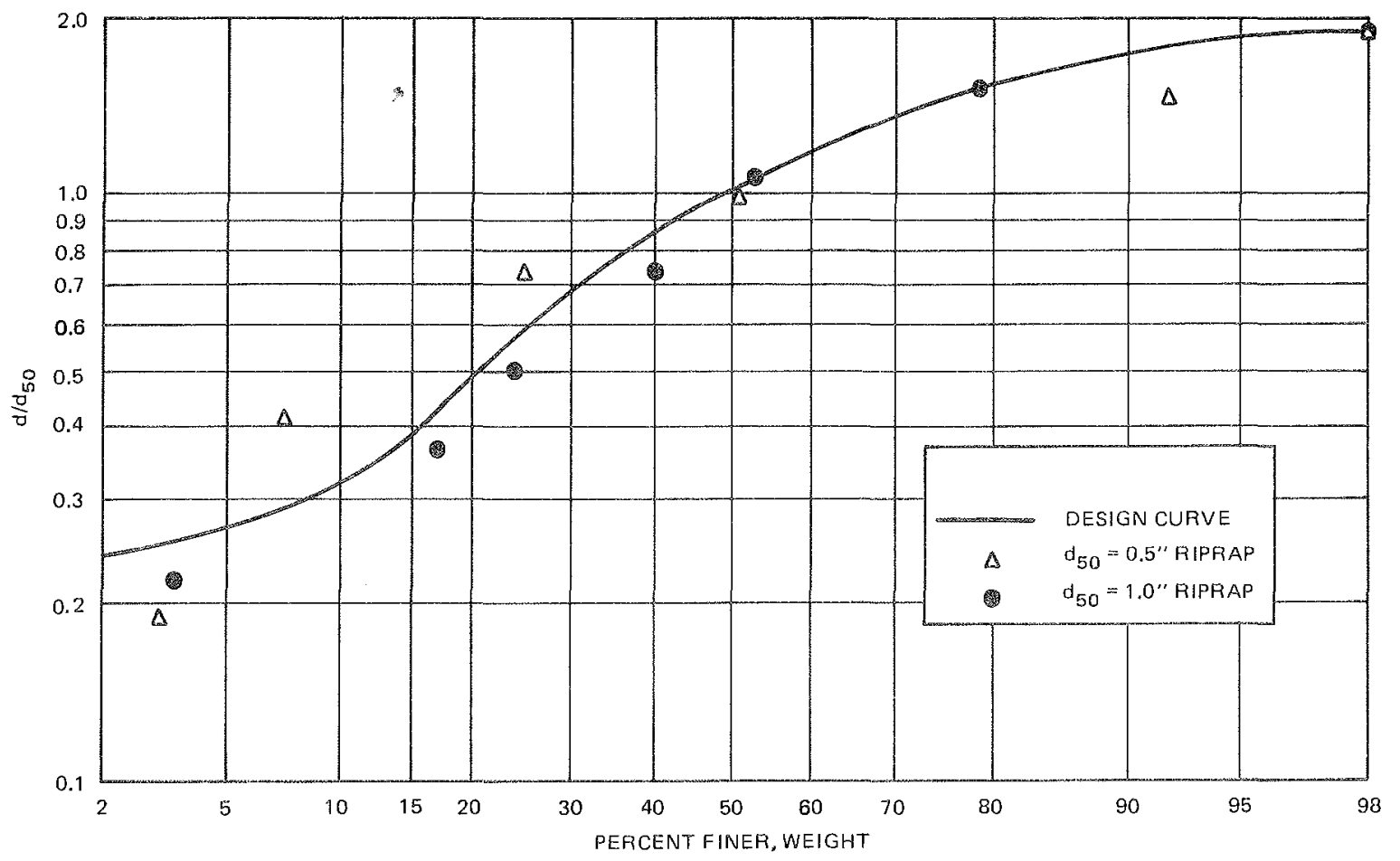

Figure 3.5. Size distribution for CSU Phase II 


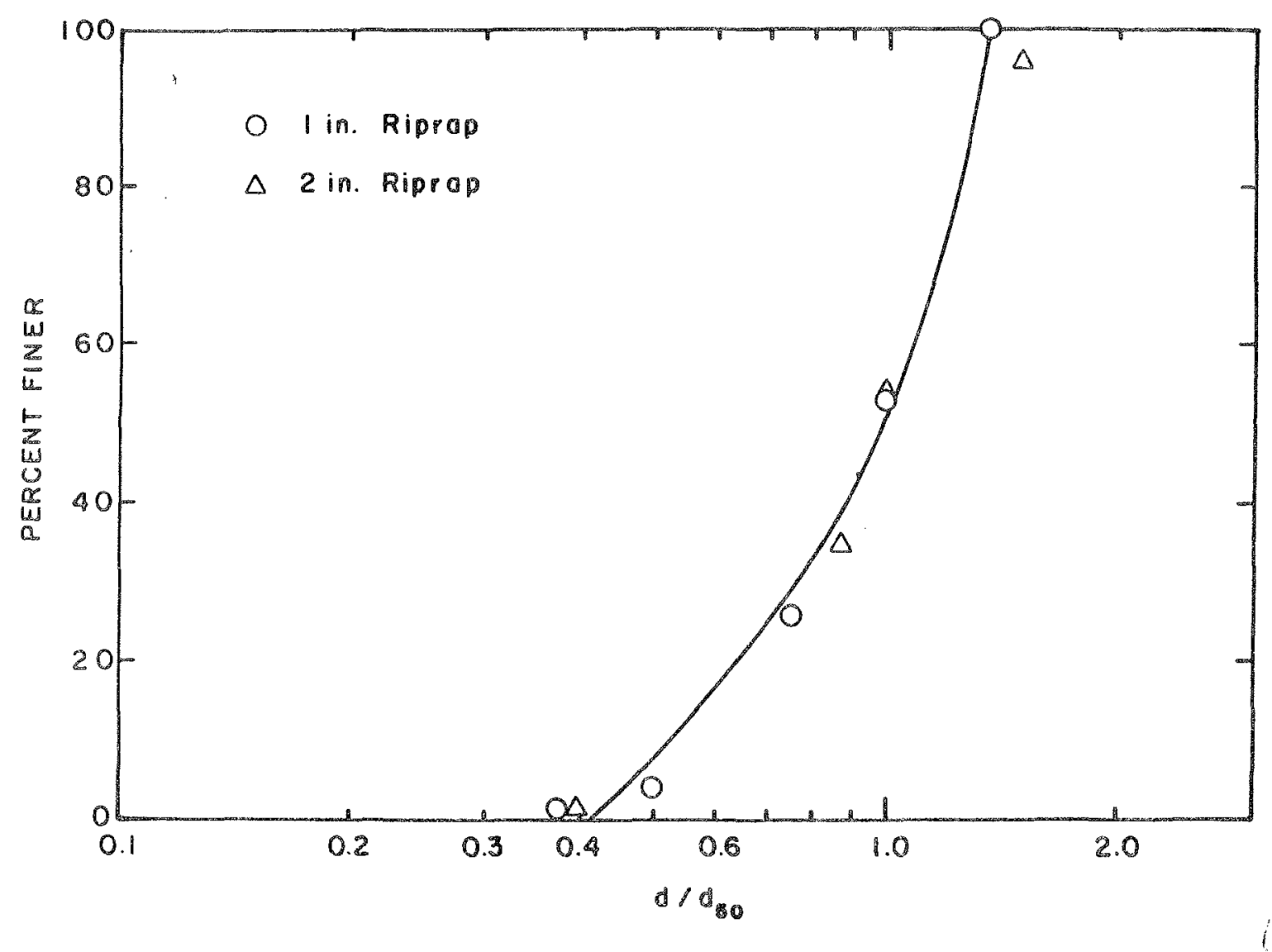

Figure 3.6. Size distribution for CSU Phase III

termed "incipient motion." Applying this technique to different riprap blanket thicknesses would probably yield litcle variation with thickness. Applying this technique to nonuniform ripraps would give biased results because some of the finer material in nonuniform ripraps will be moved without ultimate fallure of the riprap revetment.

Another existing fallure criterion is the technique used by Neill (1967), which was a visual observation of first movement. This tech nique would be successful for uniform materials bur unsuccessful for nonuniform (graded) ripraps of varying thickness. The idea of painting rocks in the test section was rejected because it would yield no information about the effects of thickness for nonuniform ripraps. 


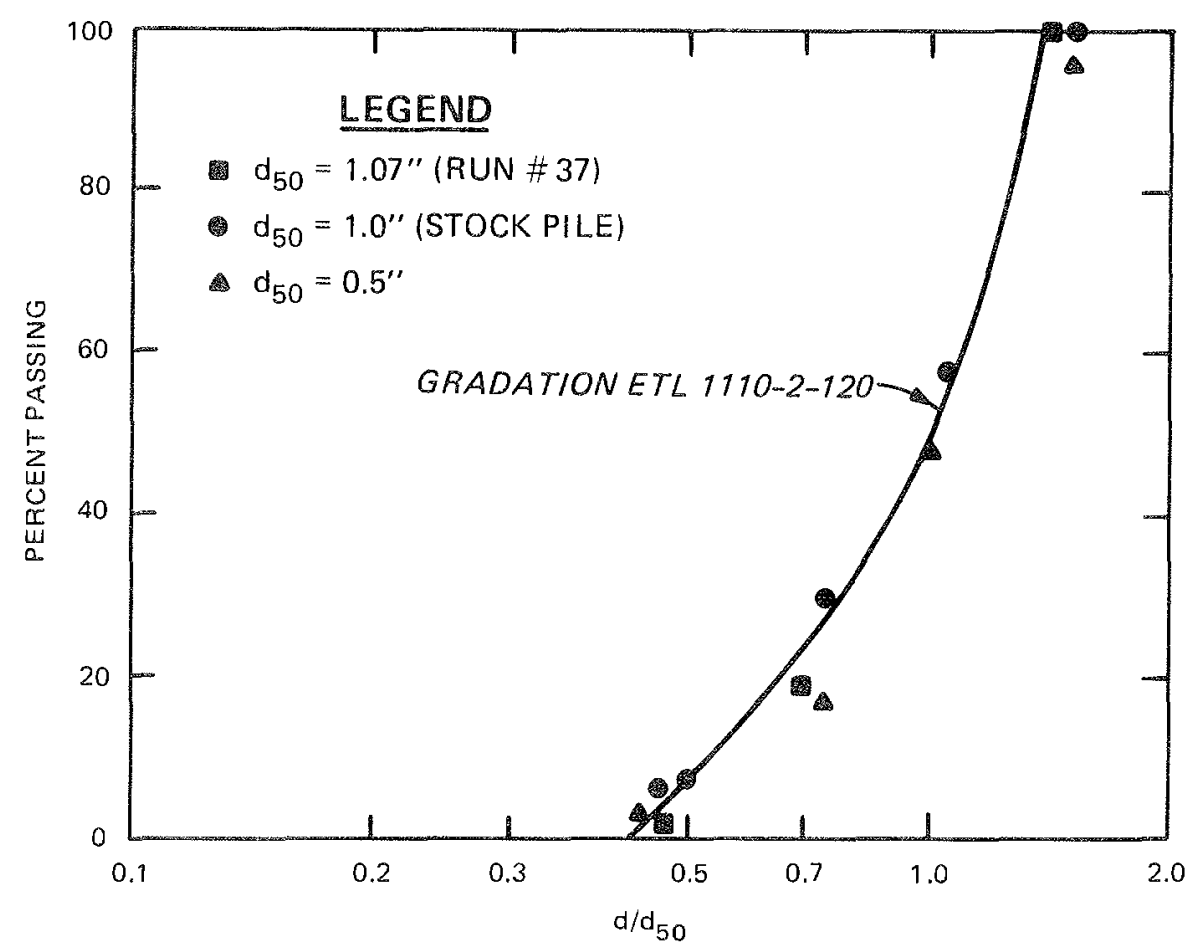

Figure 3.7. Size distribution for CSU Phase IV

An important consideration in riprap stability is that the underlying material should not be exposed to the forces of the flowing water. It is not important if some of the finer material resting on the surface of a nonuniform riprap is washed away. Another factor which must be considered with riprap stability is size segregation during placement. The selected failure criterion must be able to address the effects of size segregation when using nonuniform materials.

To meet these requirements, the concept of incipient failure is used in this investigation to define the flow conditions at which any portion of the underlying material has been exposed. Use of this failure criterion allows determination of the stability of various 
gradations and thicknesses. It is the only fallure criterion which was considered to address the effects of size segregation. The incipient failure criterion is not the same as the incipient notion criterion used In sediment transport studies. Inciplent fallure defined the flow conditions which lead to falure of the riprap blanket. Incipient motion defines the flow conditions at which the rate of particle movenent approaches zero. Inciplent motion could not be used fin this study because it would not allow determination of the effects of riprap gradation ox thickness.

\subsection{TEST PROCEDURE AND DATA COLLECTION}

In the CSU and WES trapezoidal channel tests, a fabre was used to separate the riprap from the bed of underlying sand. In the WEs tilting flume tests, the fabric was placed directly on the filume floor. While the riprap was being placed, the riprap surface was not camped or packed to best simulate prototype placement. The flow conditions at which the rock would fail were estimated using existing riprap sizing techniques. The initial test began wth low low rates and slopes well below the estimated fallure condtion. The riprap was rested for 2 hours, after Which the test section was exanined for any exposed areas of the under Iying fabric. If no exposure of the fabric occurred, the flow rates or slope was increased and the 2 -hour test repeated. This process was repeated untl the fabxic was exposed. After. the test section was repaired, the previous stable slope was run for $4-8$ hours to ensure stability of the riprap. In case of failure, the slope and/or discharge was further reduced and another 4- to 8-hour run was conducted until stable conditions were found. The WES tilting flume tests differed in 
that near the point of fallure, all runs used in the analysis were $4-$ to 8 -hour runs.

In the CSU and WES tilting flume studies, uniform flow was maintained by adjusting the tailgate at the downstream end of the flume for subcritical flows. The WES trapezoidal channel tests had a mild, grad ually varied flow regime because of the lack of slope variability. Flow uniformity in the WES curved channel model was maintained by keeping the same depth at the upstream and downstream ends of the model.

During the tests at both CSU and WES, discharges were measured by calibrated venturi and orifice meters, velocity was determined with pitot tubes and propeller meters, and depths were measured with point gages.

In the CSU tests, a "general datum" for each rock thlckness was established by the following procedures:

1. The flume was set to the horizontal position.

2. Water was added to the flume unt 11 about 90 percent of the rocks were covered with water.

3. The elevation of the water surface was measured at the locations where flow depths were neasured.

4. These elevations were considered as the elevations of the bottom of channel (general datum) in measuring the flow depth.

In the WES tests, the datum was set by placing a flat plate of known thickness on top of the riprap surface to establish the datum.

\subsection{DATA RESTRICTIONS}

Two areas of concern generally surface in the course of any flume investigation. First, flow conditions must be turbulent to ensure that viscous forces are insignificant in the flume just as they are in the 
prototype. To ensure rough turbulent flow, the following restrictions were placed on the data to be used in the analysis:
$\mathrm{J}_{*} \mathrm{~d}_{50}$
1. $\frac{2}{v}>400$
(Graf 1971)
2. $\frac{v_{50}}{v}>2.5(10)^{3}$
(0'Loughlin et al. 1970)

The second area of concern in flume studies is how to handle the effects of the sidewa11s. Previous sediment transport studies have frequently used the sidewall correcton procedure given in Vanoni (1979). This gidewa11 correction procedure results in the average bed shear stress. This method takes the central region of the flume (where the flow is essentially two-dimensional) and the two side regions (where the shear stress and velocittes are reduced) and determines a weighted average. In this type of study, the riprap generally fails and velocities are measured in the central region of the rlume. What is needed is not the welghted average but the values of shear stress and velocity in the central portion of the flume, The velocities pose no difficulty because they are measured in the cencral portion of the flume, but shear stress needs to be calculated. If the cencral portion of the flume is sufficiently wide, then the shear stress Is best approximated by $\gamma_{w}$ DS . To ensure that the central region is wide enough, Nej11 (1967) and van Rijn (1982) required that the ratio of flume bottom width $B$ to depth (aspect ratio) be equal to or greater than 5. As part of this study, the limiting aspect ratio was evalnated with velocity measurements taken in a straight, riprapped botton, smooth sidewall flume, Detalled velocity measurements were taken at aspect ratios of $4.0,4.9$, and 7.3 (Figure 3.8). The tests with aspect ratios of 4.9 and 7.3 show a 

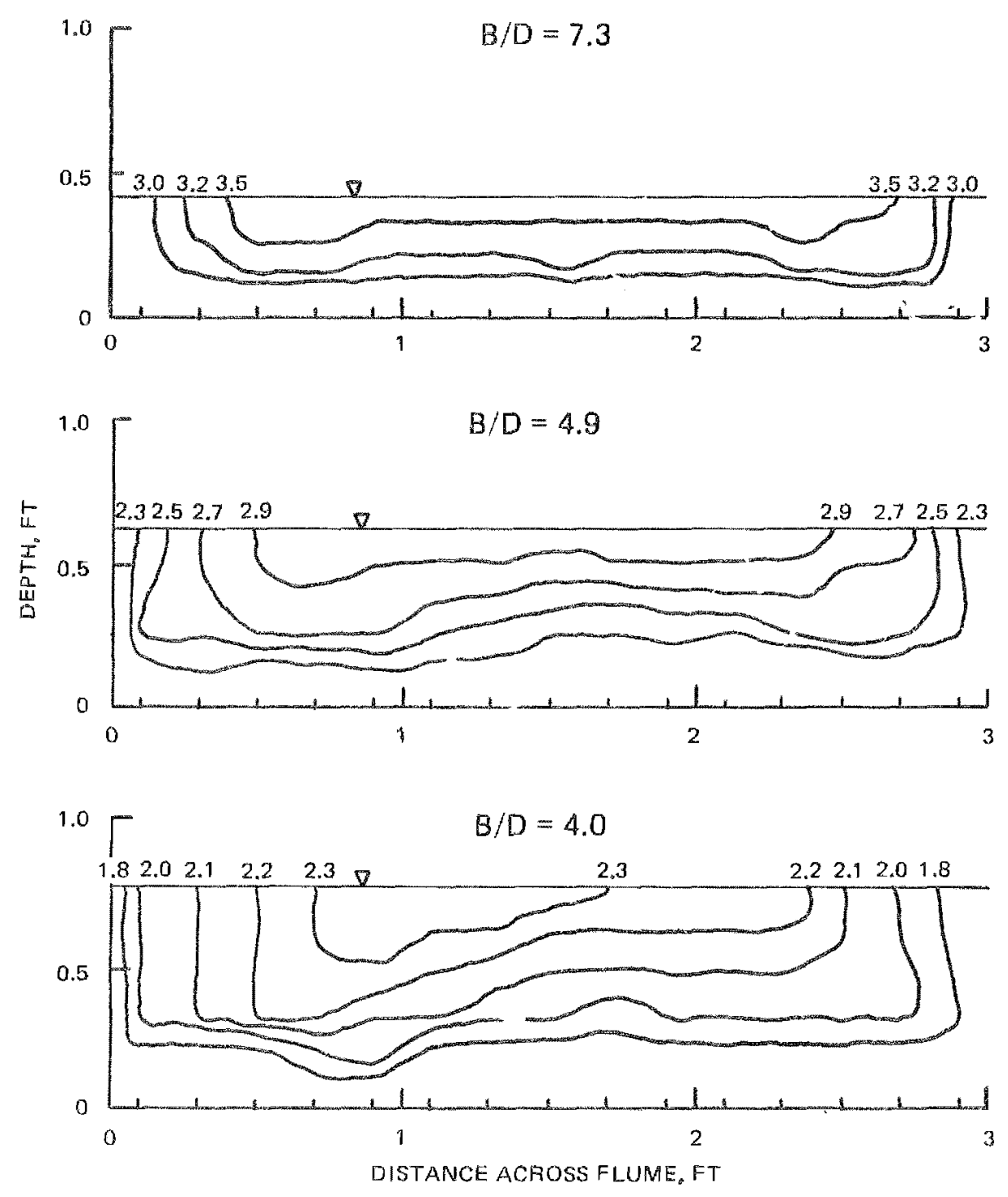

Figure 3.8. Velocity measurements used to evaluate sidewall effects relatively wide center section of essentially two-dimenstonal flow. The test at an aspect ratio of 4.0 not only shows significant sldewall effects extending out inco the flume, but an imbalance of flow across the cross section. All data used In this investigation will have an aspect ratio $>5$. This restriction on aspect ratio adaresses two other concerns relative to the csu tests: 
1. The CSU cests were generally conducted with sequential dis charges of $25,50,75$, and $100 \mathrm{cfs}$. By the time the 75- and 100-cfs tests were conducted, the xiprap in the flume was "well-seasoned." Any weak spots had already failed and had been repaired. The tests conducted at these higher discharges generally did not meet the width/depth $\geq 5$ restriction.

2. At the deeper depths, slopes were mild at the point of failure of the riprap. Only three depths were measured along the test section for each test, which made it difficult either to assume that the bottom slope equaled the energy slope or to compute the energy slope. At mild slopes, errors in determining energy slope can be large. At steeper slopes, the bottom slope domiw nates the energy slope and errors due to a limited number of depth measurements are small. This factor was probably significant only for the smallex ripraps.

Fortunately, data meeting the width/depth $>5$ requirement axe sufficient to define riprap stability for the majority of problems. 


\section{CHAPTER 4}

\section{ANALYSIS AND RESULTS}

\subsection{APPLICABITITY OF EXISTING SIZING \\ RELATIONS USING A CONSTANT \\ SHIELDS COEFFICIENT OR \\ LOGARITHMIC VELOCITY LAWS}

The review of previous work presented in Chapter 2 indicates that numerous investigations have proposed that Shields coefficient should vary with relative roughness. Experimental results from the WES and CSU tilting flunes were used to evaluate Shields coefficient as a function of relative roughness. Results from the WES trapezoidal channe1 were not used because the test section was not long enough to accurately measure the water-surface slope so that shear stress could be computed. Only those data sets covering a large range of $\mathrm{D} / \mathrm{d}$ and having the same thickness, gradation, and shape were used in this analysis. Shields coefficients computed for the four data sets meeting these requirements are shown in figures $4.1-4.4$. The data used in Figures $4.1-4.4$ are listed in Tables 4.1-4.7. Shields coefficient is computed using a combination of Equations 2.1 and 2.4 or

$$
c_{c}=\frac{\gamma_{W} D S}{\left(\gamma_{S}=\gamma_{W}\right) d_{50}}
$$

and only data meeting the limitations in Chapter 3 are used in the analysis. In a comparison of these results to the Shields (1936) work, the difference in stability criterla must be considered. The Shields (1936) investigation measured low rates of transport and extrapolated these values to a zero rate of transport to obtain incipient conditions. 


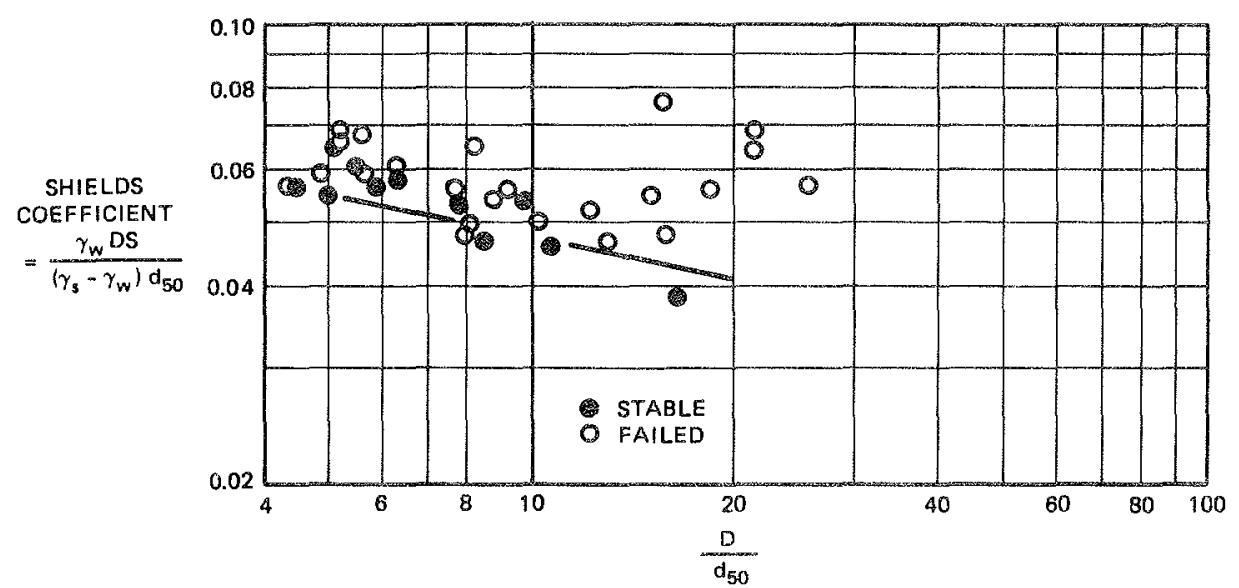

Figure 4.1. Shields ${ }^{\prime}$ coefficient versus $D / d_{50}$, thickness $=$ $1 d_{100}, d_{85} / d_{15}=1.35$ (data from Table 4.1)

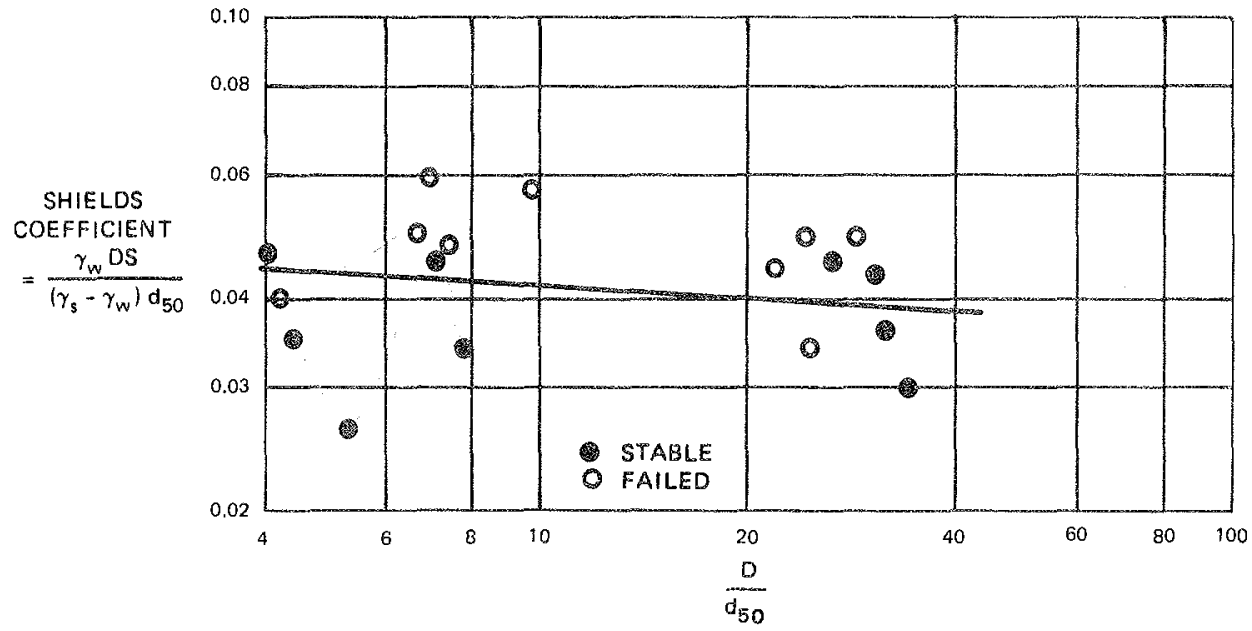

Figure 4.2. Shtelds' coefficient versus $\mathrm{D} / \mathrm{d}_{50}$, thickness $=$ $1 d_{100}=d_{85} / d_{15}=2.8$ and 2.5 (data Erom Tables 4.2 and 4.3 ) 


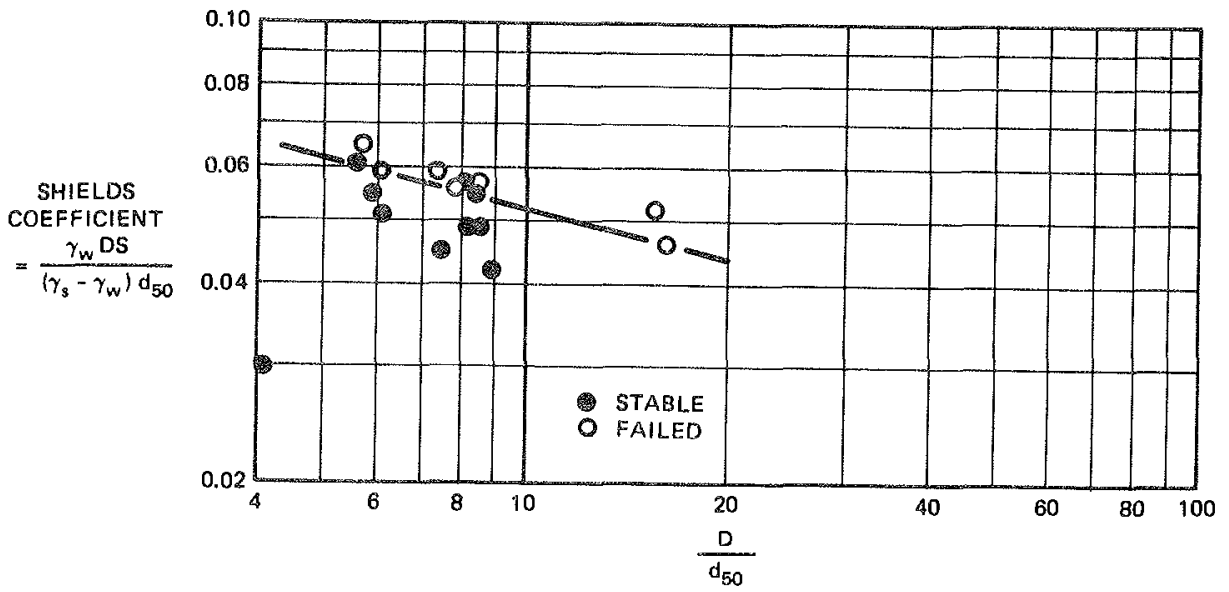

Figure 4.3. Shields" coefficient versus $\mathrm{D} / \mathrm{d}_{50}$, thickness $=1.4 \mathrm{~d}_{100}, \mathrm{~d}_{85} / \mathrm{d}_{15}=2.1$ and 2.3 (data from Tables 4.4 and 4.5 )

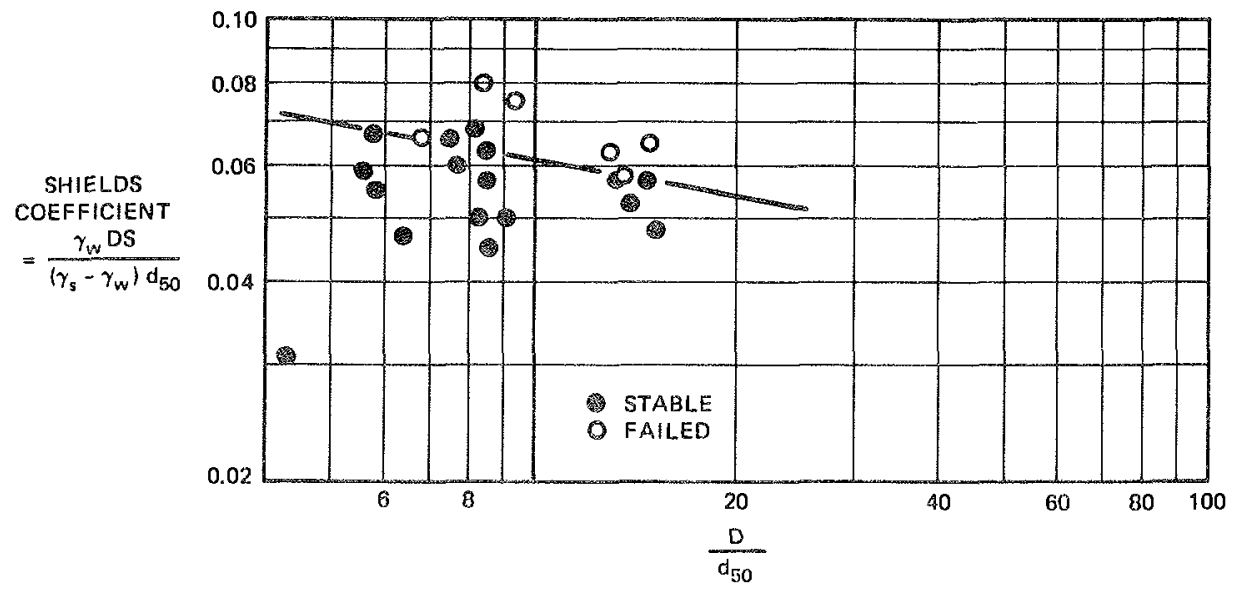

Figure 4.4. Shields' coefficient versus $D / d_{50}$, thickness $=2.1 \mathrm{~d}_{100}, \mathrm{~d}_{85} / \mathrm{d}_{15}=2.1$ and 2.3

(data from Tables 4.6 and 4.7 ) 
This investigation used the incipient failure stability critexion given in paragraph 3.3. The best-fit lines on Figures $4.1-4.4$ are drawn to separate failure runs from stable runs and are not the result of regression techniques. Three of the four data sets (Figures 4.1,4.3, and 4.4) show a significant increase in Shlelds coefficient with a decrease in $D / d_{50}$. This is the same variation proposed by several investigators cited in Chapter 2. Over the range of $D / d_{50}$ tested, there was no indication that Shields coefficient approached a constant value as proposed by Bathurst, Graf, and Cao (1982) and Bettess (1984)。The average of the best-fit lines shown in Figures $4.1,4.3$, and 4.4 show that Shields coefficient should vary according to

$$
c_{c}=c_{5}\left(\frac{d_{50}}{D}\right)^{1 / 5}
$$

which can be compared to Meyer-Peter and Muller (1948) results given in Equation 2.5.

Logarithmic velocity relations are used in riprap design to relate velocity to shear stress. Several references cited in Chapter 2 show that the logarithmic velocity relations are not applicable to high relam tive roughness and should be Iimited to small-scale roughness. The mean velocity logarithmic Equation 2.7 is the equation most frequently used in riprap design problems and will be evaluated in this analysis. The mean velocity relation results from integration of the point velocity relation over the entire depth of flow. This is one problem with the mean velocity equations, if Coleman (1981) is correct in saying that the point velocity logarithmic equation is applicable in oniy the lower 15 percent of the depth. Another problem is that the origin for the velocity profile is assumed equal to the tops of the roughness elements 
in the integration. This assumption is satisfactory for low relative roughness but not for high relative roughness. The effects of both of these assumptions are lumped into the determination of $x_{s}$. The experimental data collected in the WES and CSU flumes were used to define the applicability of the logarithmic velocity relations. Analyw sis of Equation 2.7 was similar to Yalin (1977) in which $\mathrm{K}_{\mathrm{s}} / \mathrm{d}_{90}$ is determined as a function of relative roughness. Results are presented in Figure 4.5 for tests with no movement and meeting the data requirements given in Chapter 3. Data used in Figure 4.5 are given in Tables 4.2-4.12. Results show that $\mathrm{K}_{\mathrm{s}} / \mathrm{d}_{90}$ is not constant over the range of data used in this investigation. This result is consistent with Yalin's results showing the point velocity logarithmic relation (Equation 2.6) inapplicable for $\mathrm{D} / \mathrm{d}_{90}<10$.

\subsection{DEVELOPMENT OF CRITICAL VELOCITY RELATION}

One of the objectives of this study is to develop a riprap sizing method based on velocity. Dimensional analysis is used to define the dimensionless variables based on the selection of al1 relevant parameters. The dimensional analysis is similar to that proposed by Neill (1967) in which mean velocity is used instead of the critical tractive force approach used by many investigators. The relevant parameters governing the stability of riprap in open channels are as follows:

$$
\begin{aligned}
d & =\text { characteristic particle size, } L \\
D & =\text { flow depth, } \mathrm{L} \\
\rho & =\text { fluid density, } \mathrm{M} / \mathrm{L}^{3} \\
\rho_{\mathrm{S}} & =\text { stone density, } \mathrm{M} / \mathrm{L}^{3} \\
V & =\text { mean velocity, } \mathrm{L} / \mathrm{T} \\
H & =\text { absolute viscosity, } \mathrm{M} / \mathrm{LT}
\end{aligned}
$$




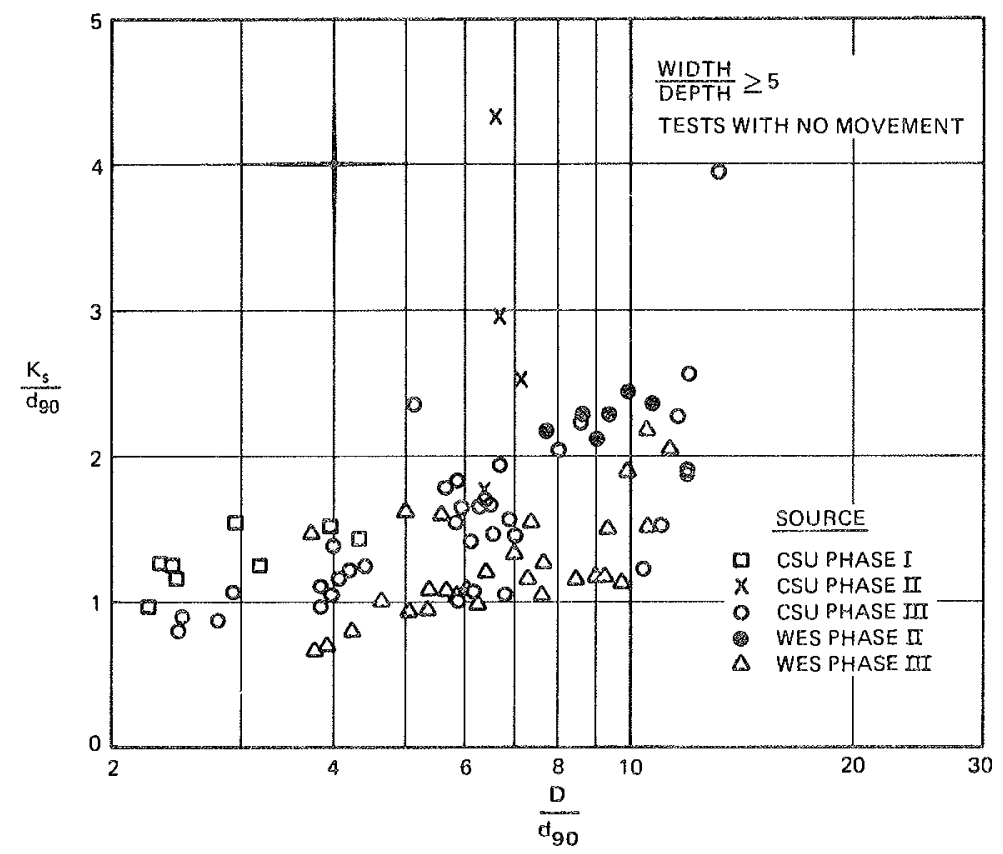

Figure 4.5. Variation of $\mathrm{K}_{\mathrm{s}} / \mathrm{d}_{90}$ with relative depth (data from Tables $4.2-4.12$ )

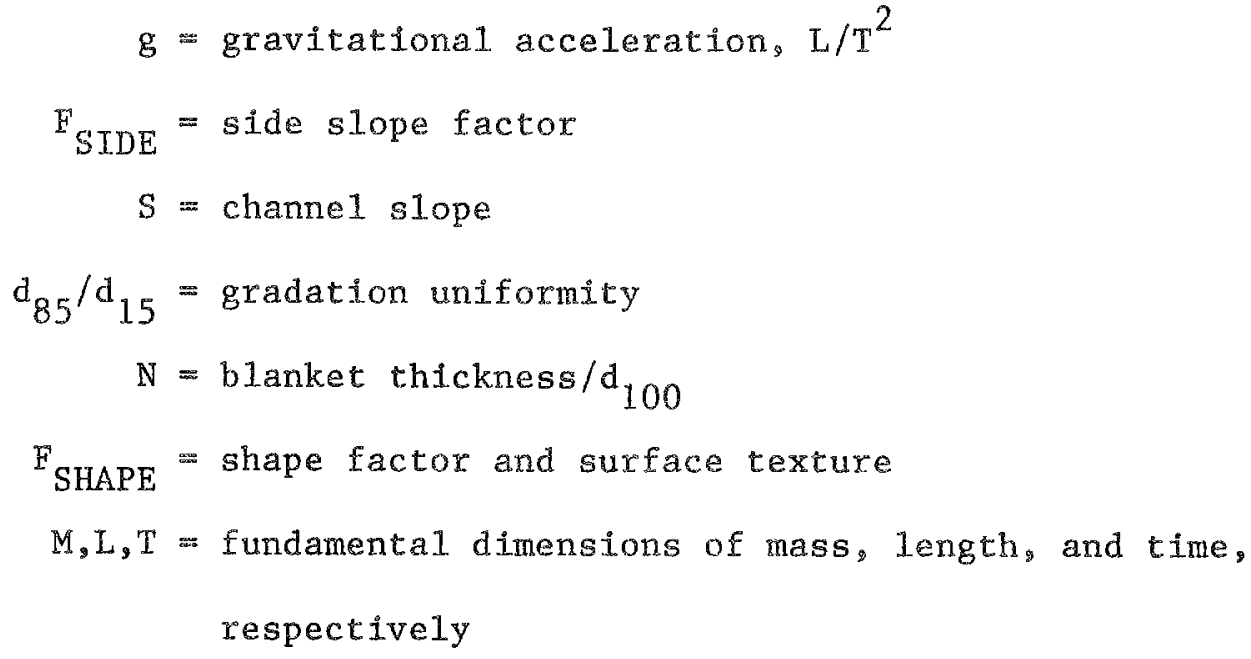

The mean velocity in this investigation is the average velocity in the vertical at the point of interest. With this concept, the effects of channel alignment or curvature can be incorporated into the design procedure. The designer must determine the velocity at the point of interest, not average crossmection values, in order to deternine rock size. Methods to determine this average velocity at the point of interest are 
presented in Chapter 5. Neither $g$ nor $\rho_{S}$ can be independent parameters; they must occur in the combination $g\left(\rho_{s}-\rho\right)$ which is the submerged specific weight of the riprap $\gamma_{s}^{\prime}$. Replacing $\mu$ with $\nu=$ $\mu / \rho$, the relevant parameters can be written

$$
f\left(\mathrm{~d}, \mathrm{D}, \rho, \mathrm{V}, \gamma_{\mathrm{S}}^{\prime}, \nu, \mathrm{F}_{\mathrm{SIDE}}, \mathrm{S}, \mathrm{d}_{85} / \mathrm{d}_{15}, \mathrm{~N}, \mathrm{~F}_{\mathrm{SHAPE}}\right)=0
$$

Out of these eleven variables there are six dimensional variables (d, $\left.D, \rho, V, \gamma_{S}^{\prime}, v\right)$ and five dimensionless quantities ( ${ }_{S I D E}, S, d_{85} / d_{15}, N$, $\left.F_{\text {SHAPE }}\right)$. Since there are three fundamental dimensions $(M, L$, and $T$ ), there are three nondimensional groups. The statement can be rewritten

$$
f\left(\pi_{1}, \pi_{2}, \pi_{3}, \mathrm{~F}_{\mathrm{SIDE}}, \mathrm{S}, \mathrm{d}_{85} / \mathrm{d}_{15}, \mathrm{~N}, \mathrm{~F}_{\mathrm{SHAPE}}\right)=0
$$

Using repeating variables $V, D$, and $\gamma_{S}^{8}$, the $\pi$ terms are

$$
\begin{aligned}
& \pi_{1}=v^{a_{1}}{ }^{b_{1}} \gamma_{s}{ }^{c_{1}}{ }_{\rho}^{d_{1}} \\
& \pi_{2}=v^{a_{2}} D^{b_{2}} \gamma_{s}^{c_{2}} d^{d_{2}} \\
& \pi_{3}=v^{a_{3}} D^{b_{3}} \gamma_{s}^{c^{c}} d^{3}
\end{aligned}
$$

Set each of $\pi^{i} \mathrm{~s}$ equal to $\mathrm{M}^{\circ} \mathrm{L}^{\circ} \mathrm{T}^{\circ}$ and solve simultaneously for a, $\mathrm{b}, \mathrm{c}$, and $\mathrm{d}$. This results in

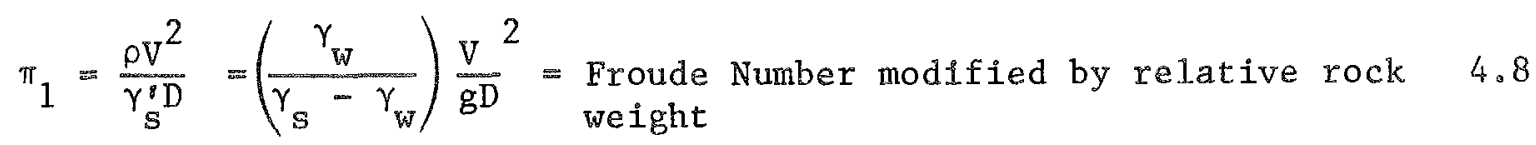

$$
\pi_{2}=\frac{d}{D}=\text { relative roughness }
$$




$$
\pi_{3}=\frac{V D}{V}=\text { Reyno.1ds' number }
$$

The statement can then be rewritten

$$
f\left[\left(\frac{\gamma_{\mathrm{w}}}{\gamma_{\mathrm{S}}-\gamma_{\mathrm{W}}}\right) \frac{\mathrm{v}^{2}}{\mathrm{gD}}, \frac{\mathrm{d}}{\mathrm{D}}, \frac{\mathrm{VD}}{\mathrm{V}}, \mathrm{F}_{\mathrm{SIDE}}, \mathrm{S}, \mathrm{d}_{85} / \mathrm{d}_{15}, \mathrm{~N}, \mathrm{~F}_{\mathrm{SHAPE}}\right]=04.11
$$

The Reynold's number term VD/ $\nu$ is indicative of viscous effects which are not important in prototypes and in the model sizes used in this investigation. The influence of slope is important for steep flows, and Bathurst, Graf, and Cao (1982) found slopes greater than 2 percent to have significant effects on incipient conditions of bed movement. At the condition of inclpient failure of riprap, slope and particle size/depth ratio $d / D$ are dependent. A steep slope implies large $d / D$ at incipient conditions. Since this investigation is limited to slopes equal to or less than 2 percent and since $d / D$ is retained in the analysis, slope is omitted. The majority of open channel riprap problems have slopes well below 2 percent. The statement of relevant dimensionless parameters becomes

$$
f\left[\left(\frac{\gamma_{w}}{\gamma_{s}-\gamma_{w}}\right) \frac{\mathrm{v}^{2}}{\mathrm{gD}}, \frac{\mathrm{d}}{\mathrm{D}}, F_{\mathrm{SIDE}}, \mathrm{d}_{85} / \mathrm{d}_{15}, \mathrm{~N}, \mathrm{~F}_{\mathrm{SHAPE}}\right]=0 \quad 4.12
$$

Riprap stability data will be used to evaluate the finportance of each of these parameters. Channel bottom test series having a relatively large range of $d / D$ and having the same gradation uniformity $d_{85} / d_{15}$, thickness $\mathbb{N}$, and shape $\mathrm{F}_{\mathrm{SHAPE}}$ were used to evaluate

$$
\frac{\mathrm{d}}{\mathrm{D}}=\text { function of }\left[\left(\frac{\gamma_{w}}{\gamma_{\mathrm{s}}-\gamma_{\mathrm{w}}}\right) \frac{\mathrm{v}^{2}}{\mathrm{gD}}\right]
$$


Results in Figures $4.6-4.9$ show that the basic equation for threshold of incipient failure of bottom riprap in straight channels has the form

$$
\frac{d_{50}}{D}=c_{6}\left[\left(\frac{\gamma_{W}}{\gamma_{s}-\gamma_{w}}\right)^{1 / 2} \frac{v}{\sqrt{g D}}\right]^{2.5}
$$

These best-fit lines were drawn to separate stable runs from failure runs and were not the result of regression techniques. Equation 4.14 is the same form found by Neil1 (1967) and Bogardi (1968) and will be used in the evaluation of the effects of gradation, thickness, and shape. Particle size $d_{50}$ was used in this analysis until additional analysis can define a characteristic size.

An equation similar to Equation 4.14 can be derived by combining the following shear or tractive force relations:

$$
\begin{gathered}
T=\gamma_{w} D S \\
T_{c}=C_{c}\left(\gamma_{s}-\gamma_{w}\right) d_{50} \\
T=T_{c} \text { (at incipient failure) } \\
C_{c}=c_{5}\left(\frac{d_{50}}{D}\right)^{1 / 5}
\end{gathered}
$$

Manning's equation

$$
V=\frac{1.49}{n} D^{2 / 3} S^{1 / 2}
$$

where $n=$ Manning's resistance coefficient and Strictler's equation is

$$
\mathrm{n}=\mathrm{C}_{7} \mathrm{~d}_{50}^{1 / 6}
$$




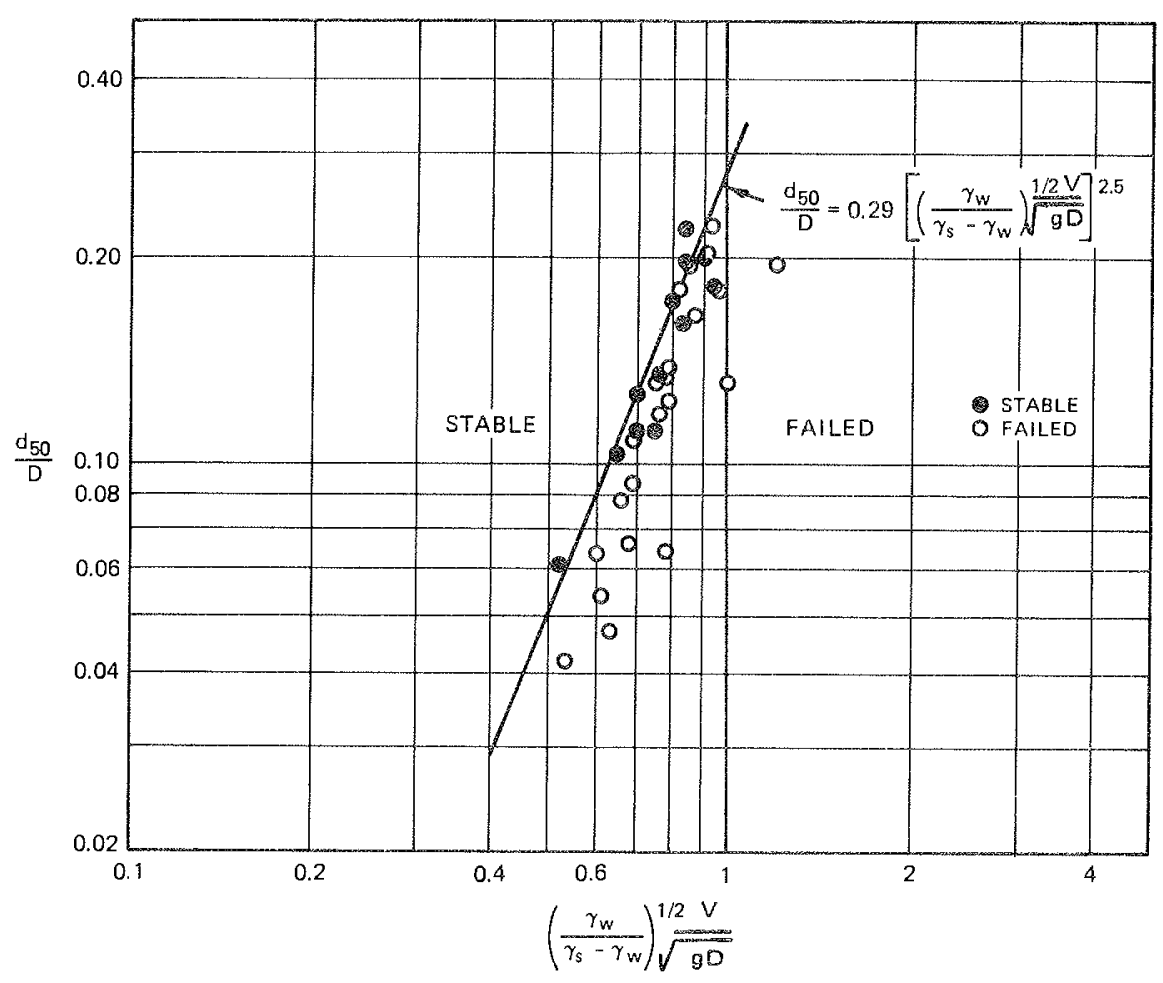

Figure 4.6. $\mathrm{d}_{50} / \mathrm{D}$ versus modified Froude number, thickness $=1 \mathrm{~d}_{100}$, $\mathrm{d}_{85} / \mathrm{d}_{15} \approx 1.35$, WES Phase I (Data from Table 4.1)

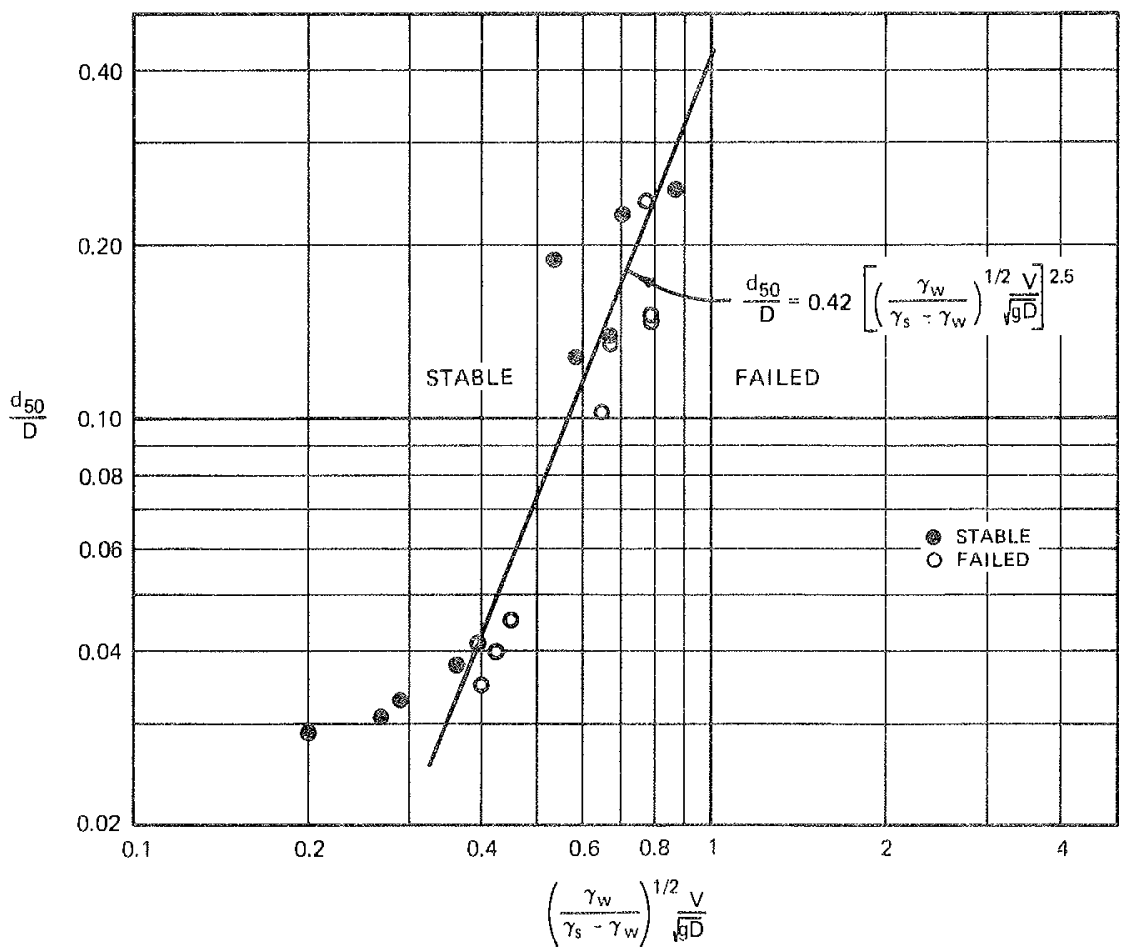

Figure 4.7. $\mathrm{d}_{50} / \mathrm{D}$ versus modified Froude number, thickness $=1 \mathrm{~d}_{100}$, $d_{85} / d_{15}=2.8$ and 2.5, CSU Phases I and II (Data from Tables 4.2 and 4.3) 


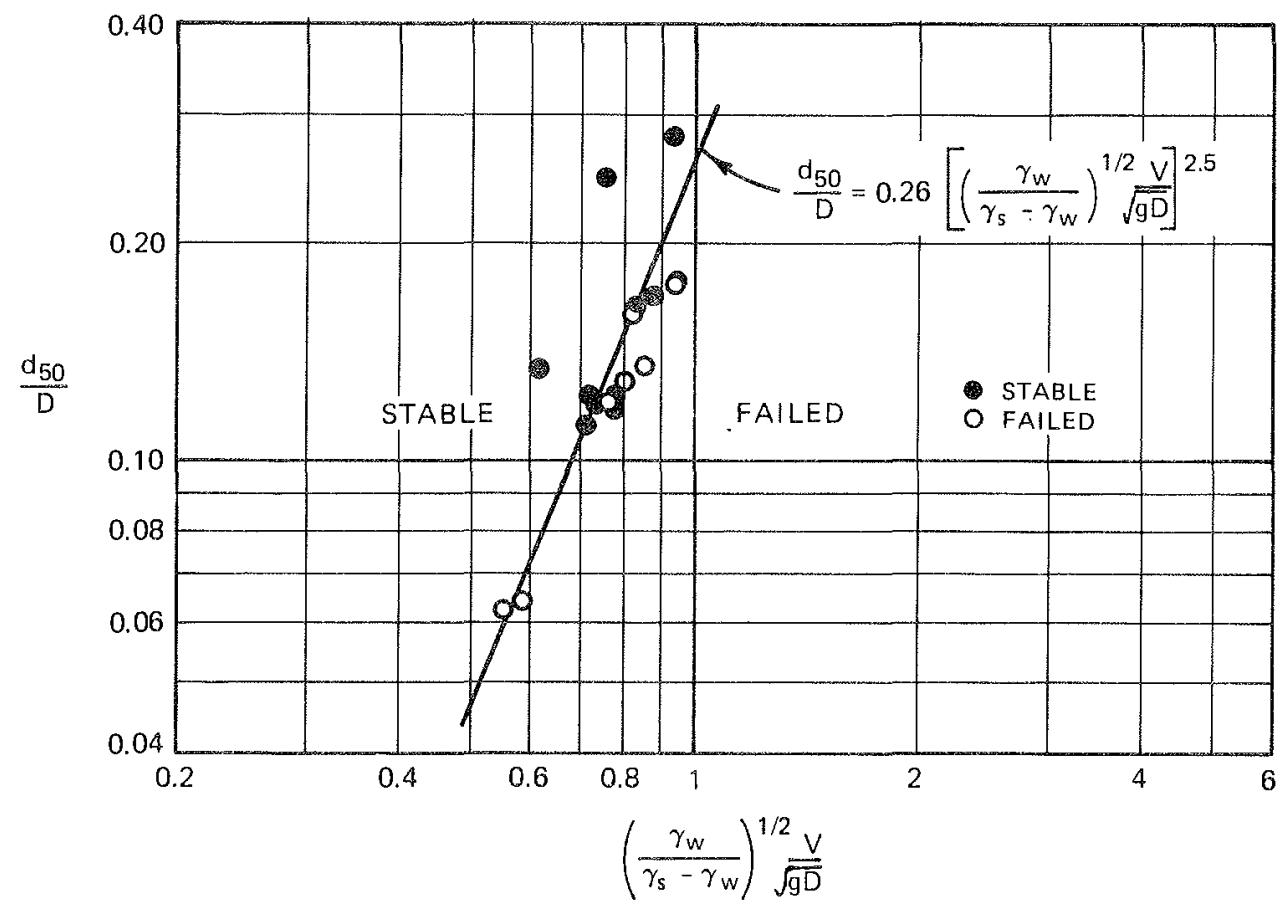

Figure 4.8. $\mathrm{d}_{50} / \mathrm{D}$ versus modified Froude number, thickness $=1.4 \mathrm{~d}_{100}$, $\mathrm{d}_{85} / \mathrm{d}_{15}=2.1$ and 2.3 , CSU Phase III (Data from Tables 4.4 and 4.5)

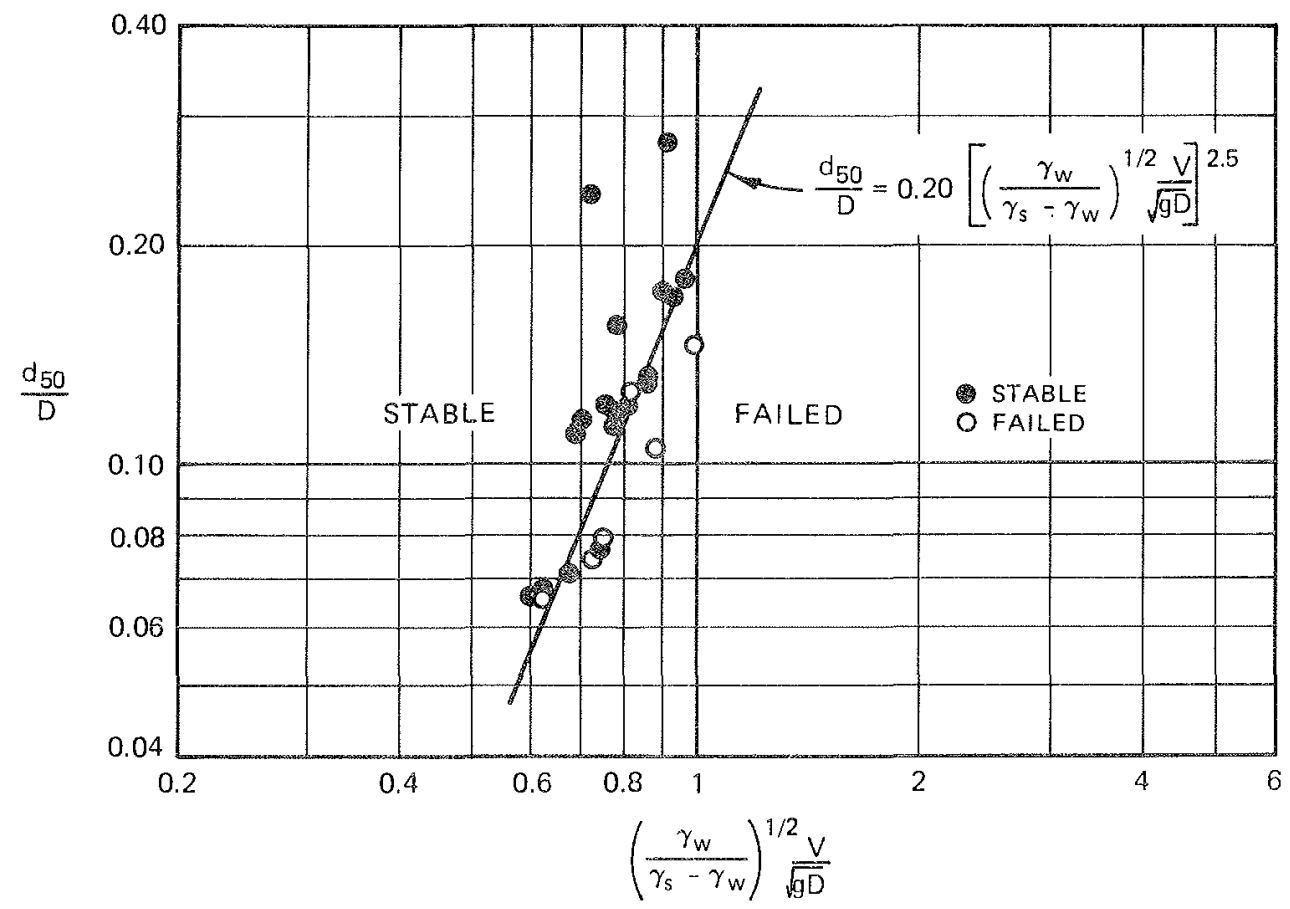

Figure 4.9. $\mathrm{d}_{50} / \mathrm{D}$ versus modified Froude number, thickness $=2.1 \mathrm{~d}_{100}$, $d_{85} / d_{15}=2.1$ and 2.3 , CSU Phase III (Data from Table 4.6 and 4.7 ) 
When combined, these equations yield

$$
\frac{d_{50}}{D}=c_{8}\left[\left(\frac{\gamma_{w}}{\gamma_{s}-\gamma_{w}}\right)^{1 / 2} \frac{\mathrm{v}}{\sqrt{g D}}\right]^{2.31}
$$

which is similar to Equation 4.14 .

Most existing riprap design procedures fall into two categories:

1. Constant Shields coefficient. Equation 2.14 is an average velocity relation which can be derived using a constant Shields coefficient and combining equations $2.1,2.4,4.15,4.16$, and 4.17.

$$
\frac{\mathrm{d}_{50}}{\mathrm{D}}=\mathrm{c}_{4}\left[\left(\frac{\gamma_{\mathrm{w}}}{\gamma_{\mathrm{s}}-\gamma_{\mathrm{w}}}\right)^{1 / 2} \frac{\mathrm{v}}{\sqrt{\mathrm{gD}}}\right]^{3}
$$

2. Isbash type relations. These can be expressed as

$$
\mathrm{d}_{50}=\mathrm{c}_{9} \mathrm{v}^{2}
$$

Many US Army Corps of Engineers (CE) offices have charts relating riprap size to velocity which use this relation. This relation can be rewritten in the form

$$
\frac{d_{50}}{D}=C_{10}\left[\left(\frac{\gamma_{w}}{\gamma_{s}-\gamma_{w}}\right)^{1 / 2} \frac{V}{\sqrt{g D}}\right]^{2}
$$

using the full form of the Isbash equation and dividing both sides by depth.

Comparing Equations 2.14 and 4.20 to the equation proposed in this investigation (previously proposed by Neill (1967) and Bogardi (1968))

$$
\frac{d_{50}}{D}=c_{6}\left[\left(\frac{\gamma_{w}}{\gamma_{s}-\gamma_{w}}\right)^{1 / 2} \frac{\mathrm{V}}{\sqrt{g D}}\right]^{2.5}
$$


shows that riprap stability is best described by a relationship with an exponent that falls halfway between the two most commonly used methods of design.

\subsection{EFFECTS OF GRADATION, THICKNESS, AND SHAPE ON RIPRAP STABILITY}

4.3.1 Gradation. Variation of gradation unfformity was accounted for by using a characteristic size less than the average size given in several references cited in the literature review. Size segregation can be a significant factor when using highly nonuniform materials and is probably one reason the characteristic size was found to be less than the average size. The ratio $\mathrm{d}_{85} / \mathrm{d}_{15}$ is used to describe the uniformity of riprap gradations. Standard CE gradations given in OCE (1971) have $\mathrm{d}_{85} / \mathrm{d}_{15}=1.8-2.1$. In addition to the results presented in Figures 4.6-4.9, data from the following test series were evaluated using Equation 4.14 (these data sers were not used in the development of Equation 4.14 because they do not cover a wide enough range of d/D).

$\begin{array}{cccccc}\text { Source } & \frac{\mathrm{d}_{85} / \mathrm{d}_{15}}{} & & \text { Thickness } & \text { Tab1e } & \text { Figure } \\ \text { CSU Phase I } & 3.9 & 1 \mathrm{~d}_{100} & 4.8 & 4.10 \\ \text { CSU Phase II } & 4.6 & 1 \mathrm{~d}_{100} & 4.9 & 4.11\end{array}$

To evaluate the effects of gradation for riprap placed to a thickness of $1 \mathrm{~d}_{100}$, the coefficients from the equations shown in Figures $4.6,4.7,4.10$, and 4.11 are plotted against $a_{85} / d_{15}$ in Figure 4.12. Results show that the coefficient varies with $\mathrm{d}_{85} / \mathrm{d}_{15}$, which means that $d_{50}$ is not the characteristic size for the range of gradations tested. Equation 4.14 was evaluated using different characteristic sizes, and only $\mathrm{d}_{30}$ (Figure 4.12) was shown to give a 


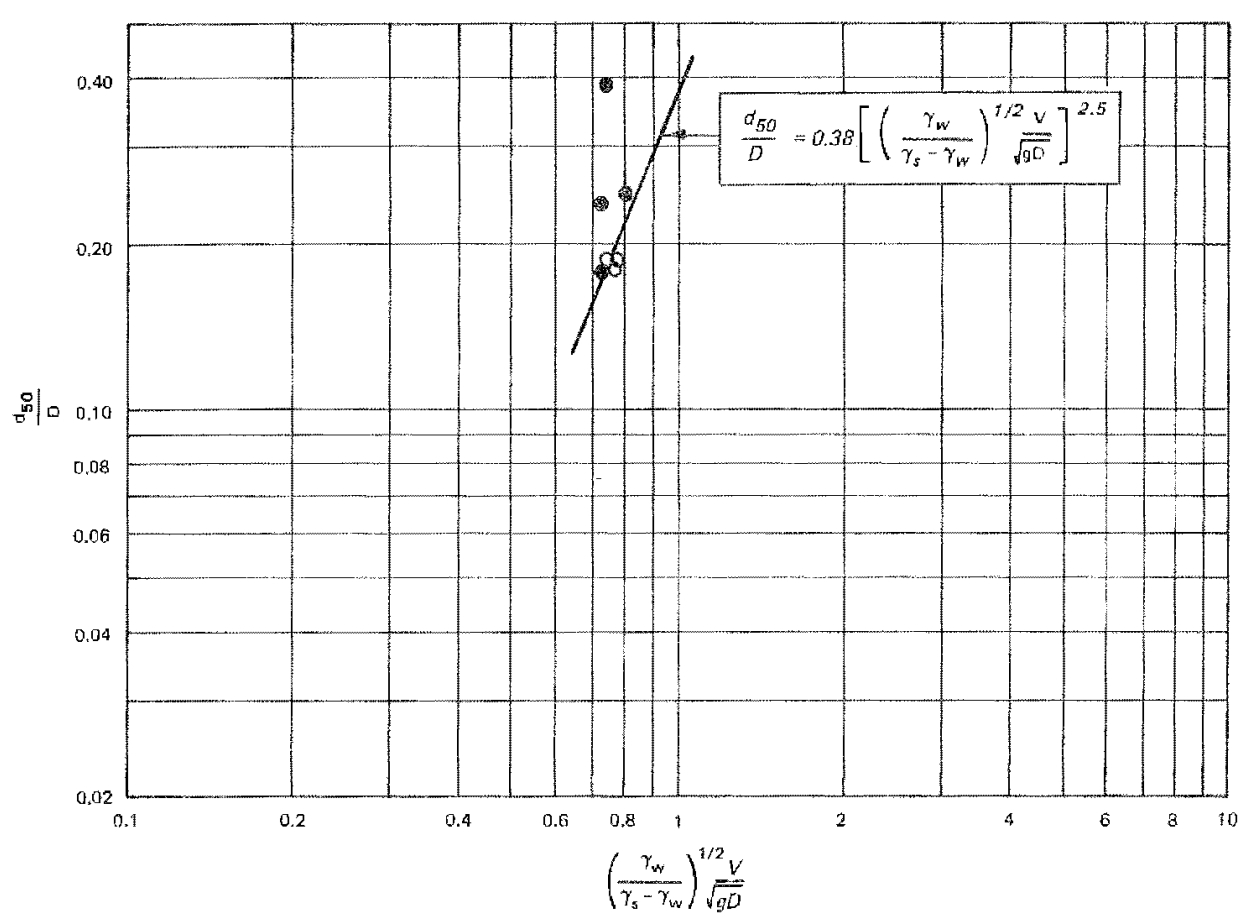

Figure 4.10. $d_{50} / D$ versug modified Froude number, thickness $=1.0 \mathrm{~d}_{100}, \mathrm{~d}_{85} / \mathrm{d}_{15}=3.9$, CSU Phase I (Data from Table 4.8)

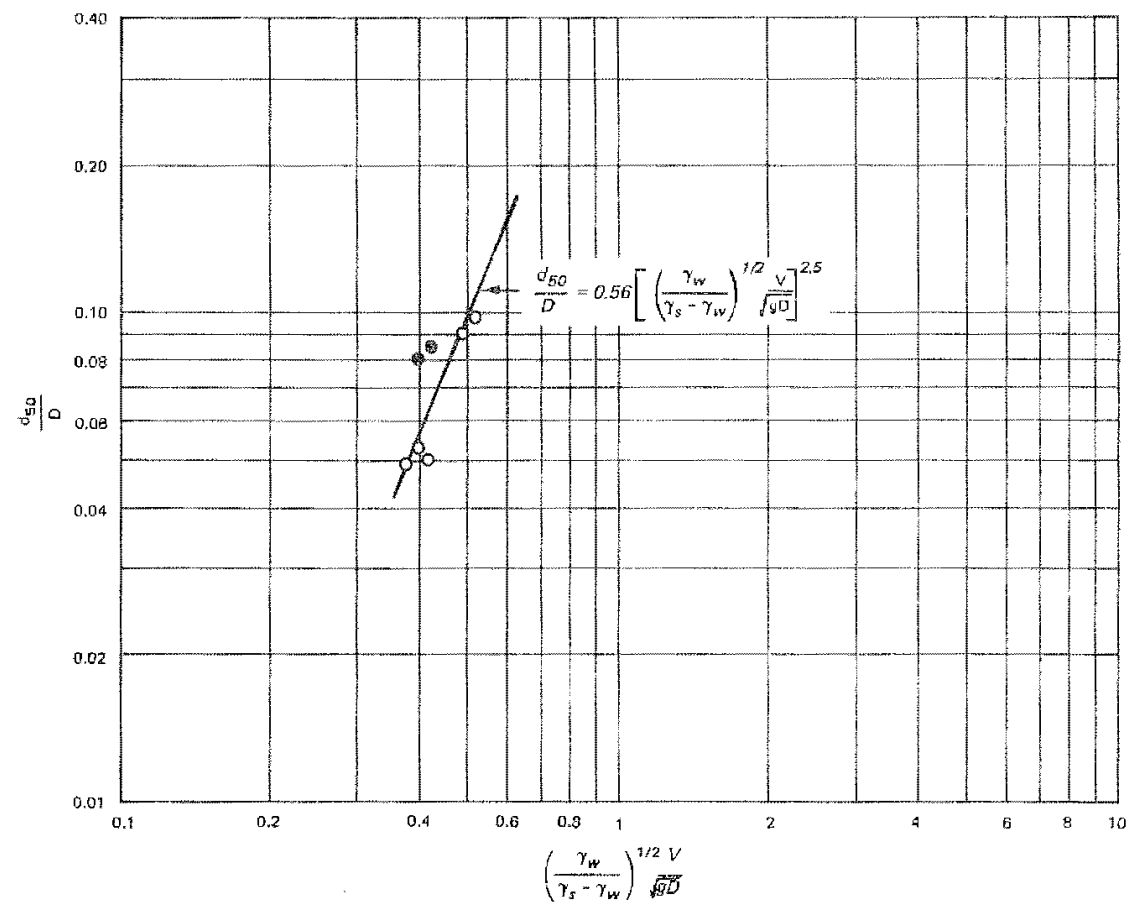

Figure 4.11. $d_{50} / D$ versus modified Froude number, thickness $=1.0 \mathrm{~d}_{100}, \mathrm{~d}_{85} / \mathrm{d}_{15}=4.6$, CSU Phase II (Data from Table 4.9) 


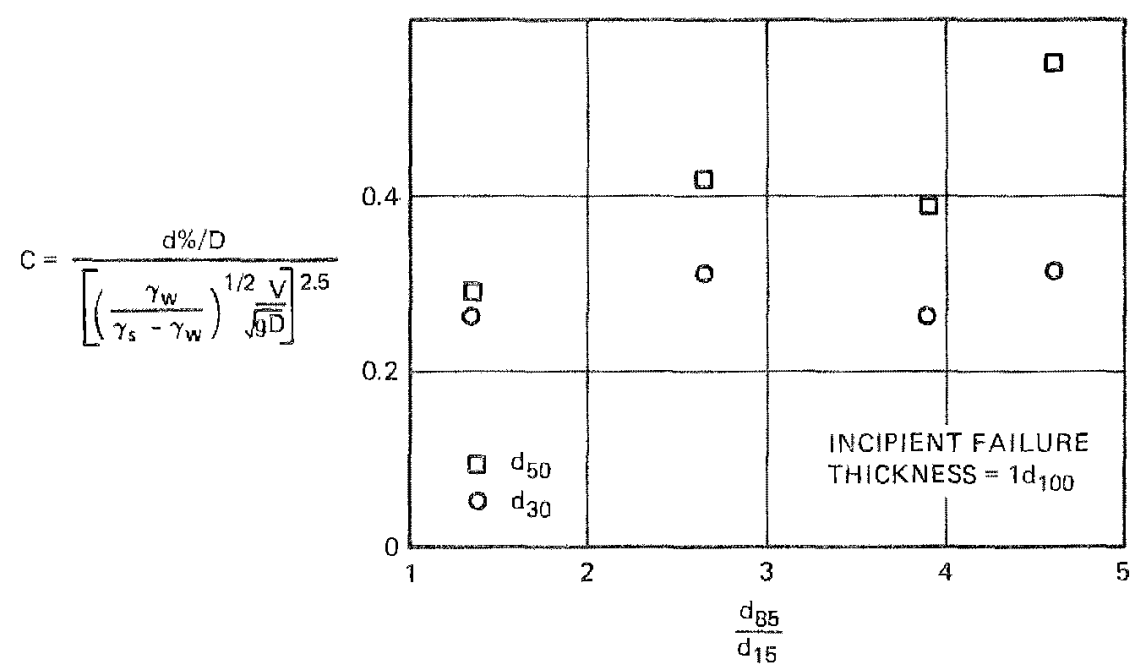

Figure 4.12. Coefficient in Equation 4.14 versus $\mathrm{d}_{85} / \mathrm{d}_{15}$, thickness $=1 \mathrm{~d}_{100}$, bottom riprap

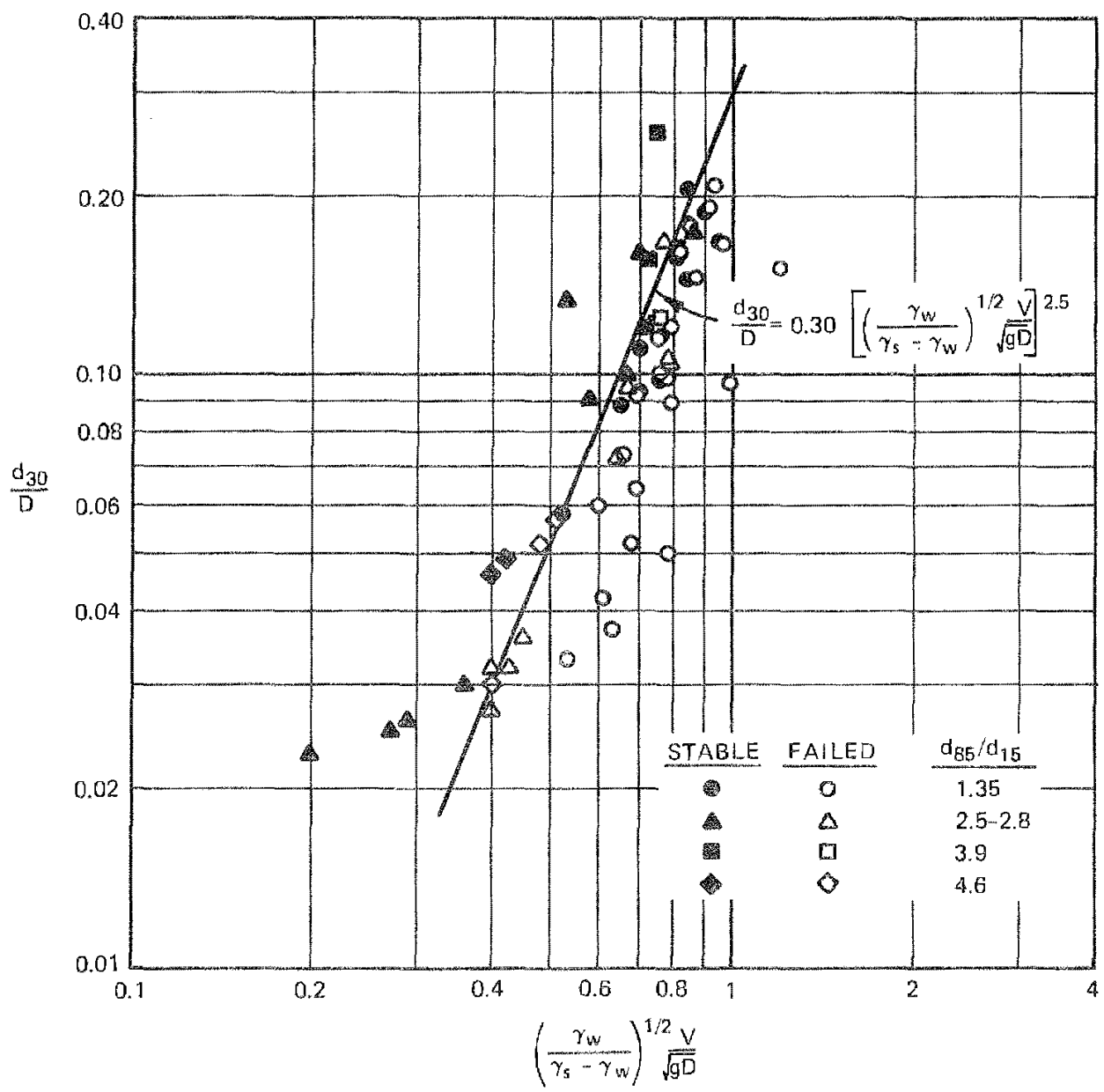

Figure 4.13. $\mathrm{d}_{30} / \mathrm{D}$ versus nodifled froude number, thickness $=1 \mathrm{~d}_{100}, \mathrm{~d}_{85} / \mathrm{d}_{15}=1.35-4.6$, bottom 
relatively constant $C$ in Equation 4.14. All data are plotted in Figure 4.13. The equation

$$
\frac{\mathrm{d}_{30}}{\mathrm{D}}=0.30\left[\left(\frac{\gamma_{\mathrm{w}}}{\gamma_{\mathrm{S}}-\gamma_{\mathrm{w}}}\right)^{1 / 2} \frac{\mathrm{V}}{\sqrt{\mathrm{gD}}}\right]^{2.5}
$$

is applicable to threshold of incipient failure of riprap placed to a thickness of $1 \mathrm{~d}_{100}, \mathrm{~d}_{85} / \mathrm{d}_{15} \leq 4.6, \mathrm{~d}_{30} / \mathrm{D}=0.020-0.25, \mathrm{~F}<1.2$, on the bottom of straight channels. This analysis shows that either $d_{50}$ can be used in Equation 4.14 with a coefficlent which varies with gradation or $\mathrm{d}_{30}$ can be used in Equation 4.21 .

4.3.2 Thickness. Several of the test series were used to determine the effects of blanket thickness on riprap stability. Any comparison of different thicknesses of riprap must be conducted with the same gradation. Data from Maynord (1978) are shown in Figure 4.14 for a thickness of $1.5 \mathrm{~d}_{100}$. The following tabulation sumarizes the test series used in the analysis of thickness effects:

\begin{tabular}{|c|c|c|c|c|c|}
\hline Source & $\mathrm{d}_{85} / \mathrm{d}_{15}$ & Thickness & $\mathrm{d}_{30} / \mathrm{d}_{50}$ & Table & Figure \\
\hline $\begin{array}{l}\text { WES trapezoidal } \\
\text { channel }\end{array}$ & 2.0 & $1.5 d_{100}$ & 0.83 & $\begin{array}{l}\text { See Maynord } \\
(1978)\end{array}$ & 4.14 \\
\hline CSU Phase III & $2.1-2.3$ & $1.4 d_{100}$ & 0.80 & $4.4,4.5$ & 4.8 \\
\hline CSU Phase III & $2.1-2.3$ & $2.1 d_{100}$ & 0.80 & $4.6,4.7$ & 4.9 \\
\hline
\end{tabular}

The coefficients from these equations are determined for a characteristic size $\mathrm{d}_{30}$ and plotted against thickness in Figure 4.15. For thickness of $1.0 \mathrm{~d}_{100}$, the coefficient from Equation 4.21 is used. Results show that increased thickness decreases the size required to remain stable up to a thickness of $2.0-2.5 \mathrm{~d}_{100}$. Additional tests are needed to evaluate the effects of thickness for other gradations. Note that $d_{30}$ was shown to be the characteristle size for a thickness of $1.0 d_{100}$ only. As riprap thickness increases, the likelihood of areas having 


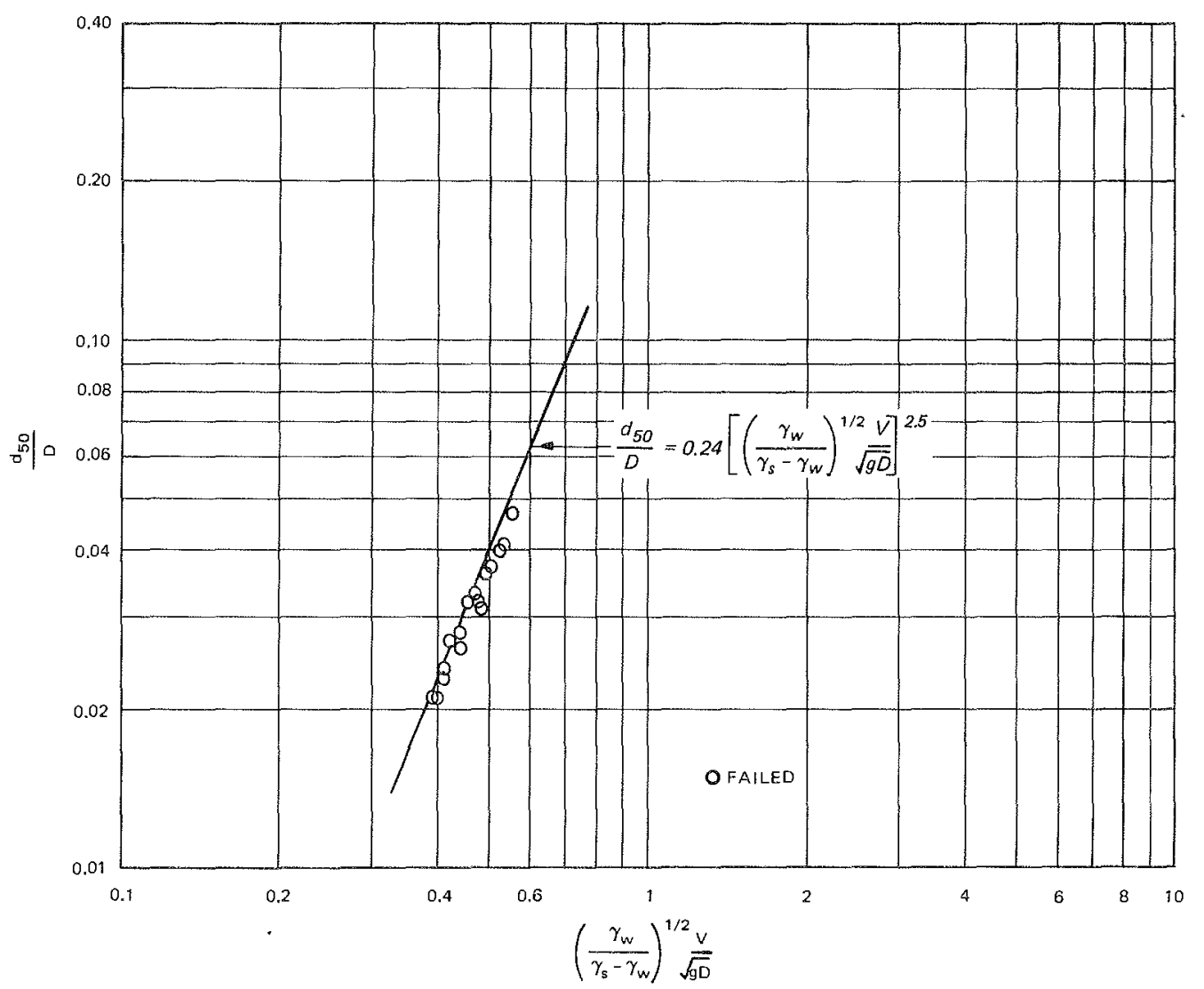

Figure 4.14. $\mathrm{d}_{50} / \mathrm{D}$ versus modified Froude number, thickness $=1.5 \mathrm{~d}_{100}, \mathrm{~d}_{85} / \mathrm{d}_{15}=2.0$, WES trapezoidal

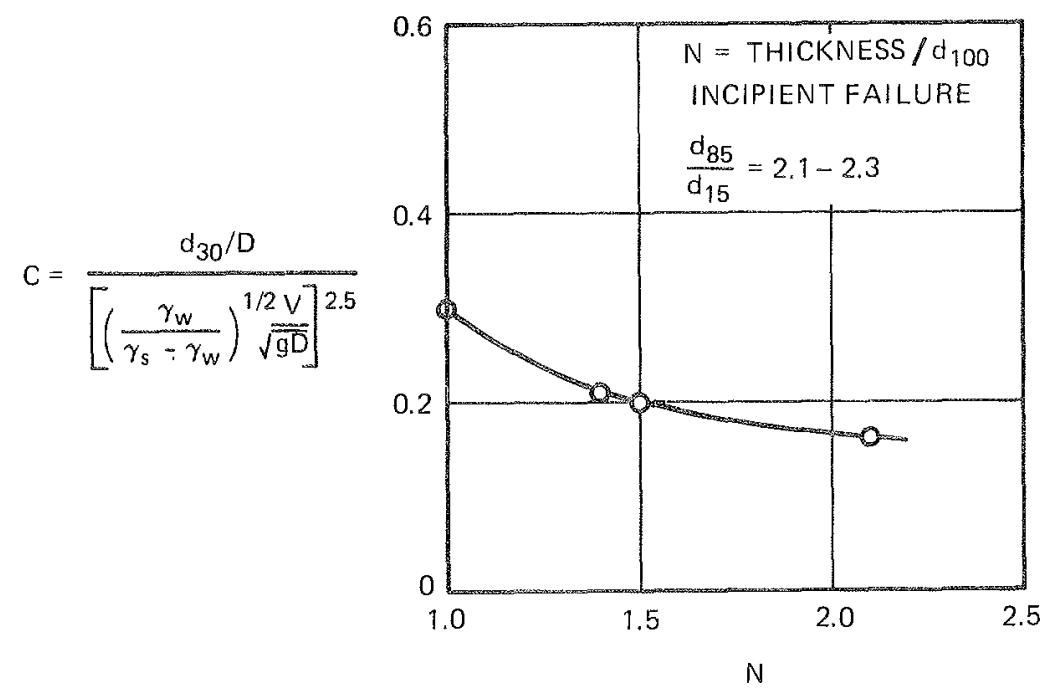

Figure 4.15. Coefficient in Equation 4.21 (using $d_{30}$ ) versus blanket thickness, $d_{85} / d_{15}=2.1-2.3$, bottom riprap 
only smal1 particles (due to size segregation) decreases. Another mechanism, armoring, may also exert a significant influence on riprap stability. These may be the reasons that thickness is seen to be so significant in Figure 4.15 .

4.3.3 Shape. Two of the test series conducted during the CSU Phase III tests allow a comparison of the effects of iontap shape. OCE (1970) shape guidance requires the following:

1. Stone predominantly angular

2. No more than 25 percent of stones having $\ell / b>2.5$

3. No stone having $\ell / b>3.0$

Riprap meeting this guidance was tested and compared with riprap having the following characteristics:

1. Al1 stone angular

2. Thirty percent of stone had $\ell / b>2.5$

3. Eighteen percent of stone had $l / b>3.0$

Results of these two test series are plotted in Figure 4.16. Data used in Tigure 4.16 are from Tables 4.4 and 4.10 . Results show that shape effects are insignificant within the range tested in this investigation. Neil1 (1967) also found shape effects to be small. The stability of rounded rock such as cobbles was not addressed in this investigation. 4.4 EFFECTS OF SIDE SLOPE ON RIPRAP STABILITY

Three areas must be addressed in defining the effects of channe1 side slopes on xiprap stability. First, the effects of the grav1ty component acting downslope and the influence of angle of repose must be evaluated. Second, the effects of the side slope on the velocity profile and distribution must be incorporated into the average velocity relations for sizing riprap. Third, side slope stability tests must be 


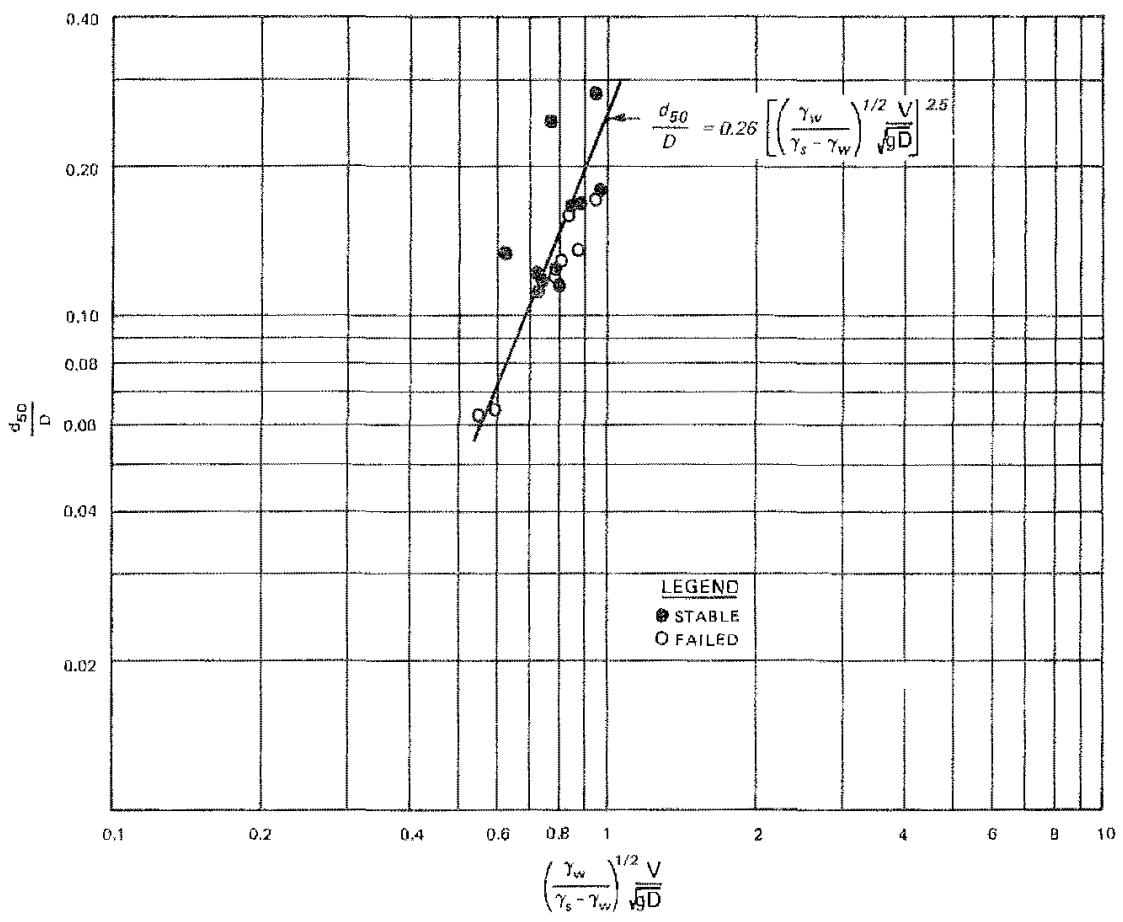

a. Meets Corps shape criteria (Data from Table 4.4)

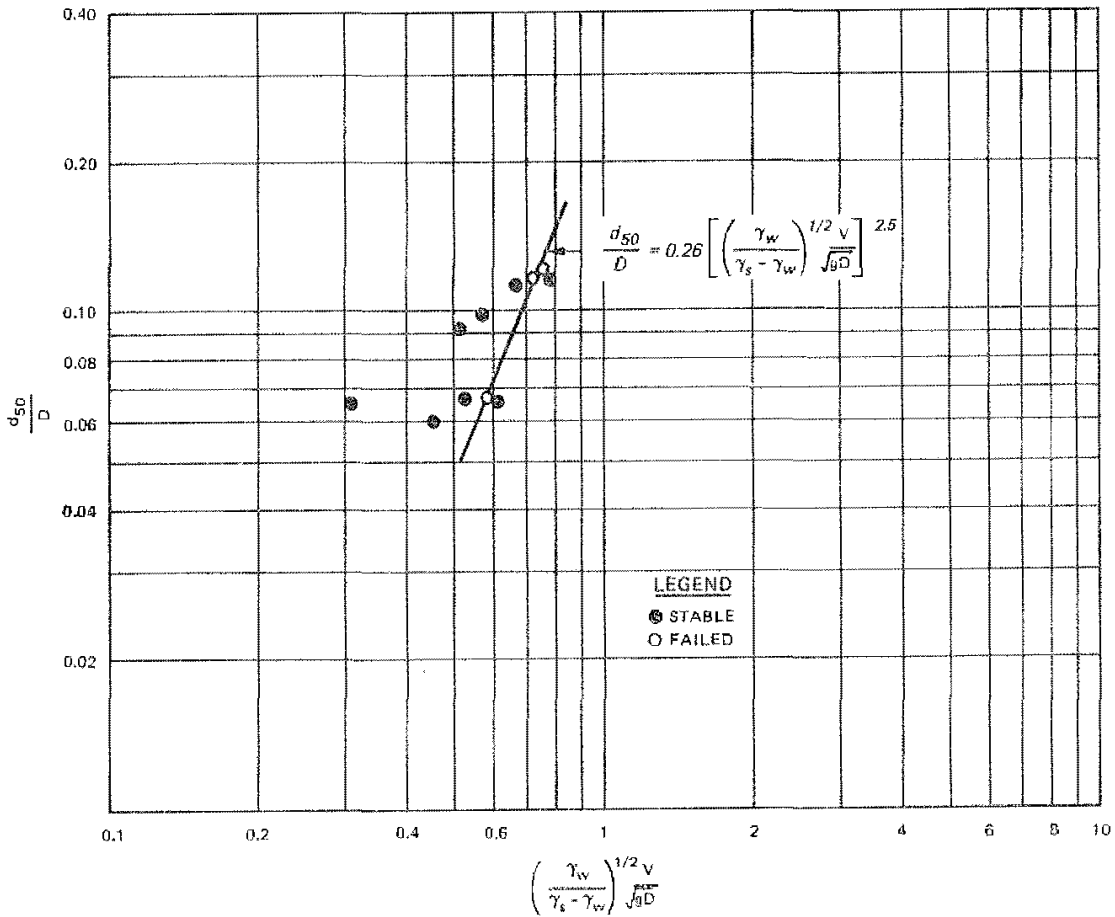

b. Does not meet Corps shape criteria because of excess elongated particles (Data from Table 4.10)

Figure 4.16. Shape effects comparison, $\mathrm{d}_{85} / \mathrm{d}_{15}=2.1-2.3$, thickness $=1.4 d_{100}$, CSU Phase III 
conducted to determine the combined effect of the gravity component and the velocity profile.

4.4.1. Effect of Gravity Component Acting Downslope. As indicated in the literature review, several different methods including equilibrium of moments and equilibrium of forces have been used to define the stability of a particle resting on a channel side slope. As part of this investigation, tests were conducted in the WES tilting flume (Phase TV) to compare the stability of riprap resting on various side slopes. A schematic of the test faclilty is shown in Figure 4.17. The side slope was hinged at the bottom of the slope to facilitate changing the side slope. The riprap surrounding the test section was the same size as used in the test section and was glued to the side slope to ensure that the velocity profile and turbulence characteristics of the approach flow did not vary from test to test. Results for six different side slopes using uniform riprap with a thickness of ${ }^{1} d_{100}$ are shown In Table 4.13. Bottom velocity was used to define the imposed velocity and was measured $2.9 d_{50}$ above the side slope as shown in Figure 4.18 . Results show decreasing bottom velocity for increasing side slope.

The tractive force ratio as used by Carter, Carlson, and Lane (1953) is

$$
k=\frac{T_{s}}{T_{c}}=\cos \theta \sqrt{1-\frac{\tan ^{2} \theta}{\tan ^{2} \phi}}=\sqrt{1-\frac{\sin ^{2} \theta}{\sin ^{2} \Phi}}
$$

Given the same fluid, particle characteristics, and depth, shear stress is proportional to the second power of the velocity

$$
T=C_{11} \nabla^{2}
$$

The WES tilting flume side slope tests were conducted with the same fluid, particle characteristics, and depth. The only factor that varied 

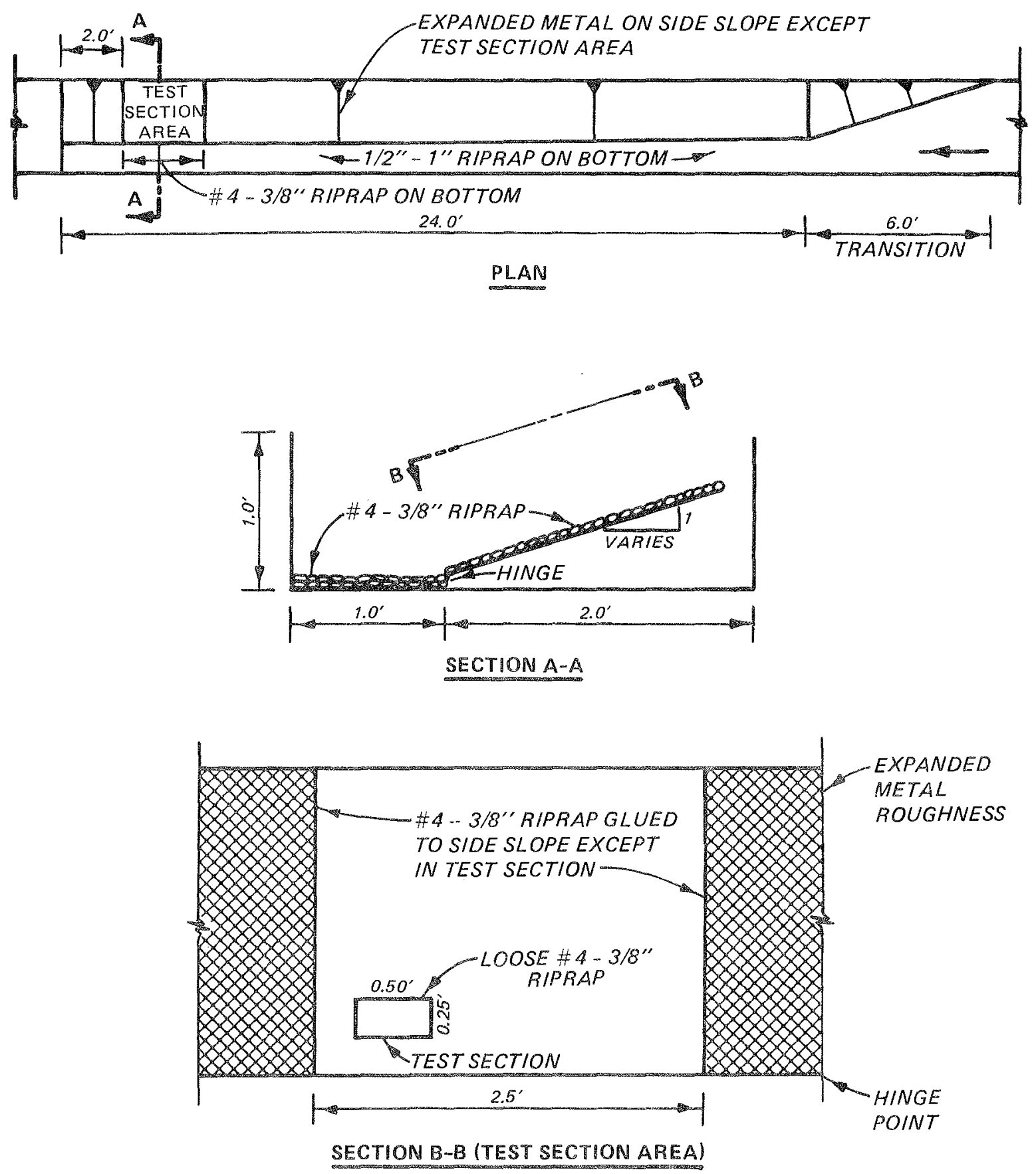

Figure 4.17. WES side slope test flume 


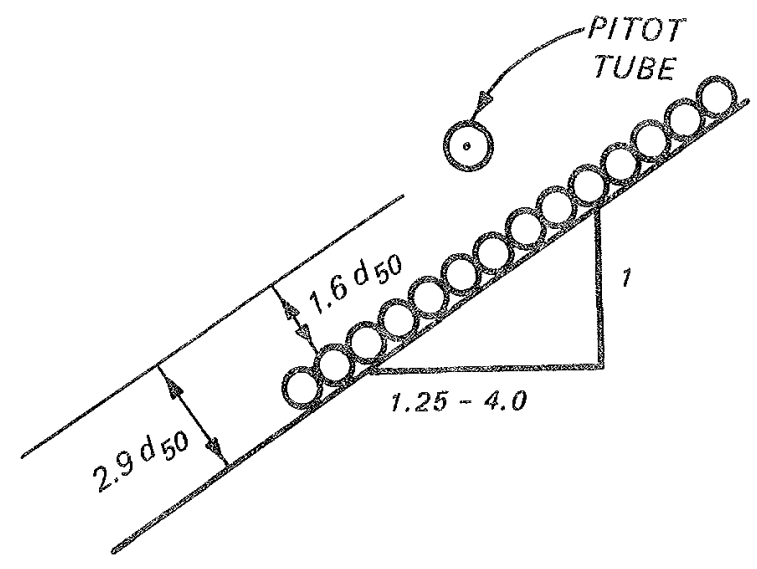

Figure 4.18. Location of botton velocicy measurenents in WES tilting flume side slope tests

was the side slope angle. Having established these conditions Equation 4.22 can be substicuced into 2.17 to obtaln

$$
\mathrm{K}=\frac{\mathrm{T}_{\mathrm{s}}}{\mathrm{T}_{\mathrm{c}}}=\frac{\mathrm{V}_{\mathrm{s}}{ }^{2}}{\mathrm{v}_{\mathrm{C}}^{2}}
$$

where

$$
\begin{aligned}
& V_{S}=\text { critical velocity for particle on side slopes } \\
& V_{c}=\text { critical velocity for particle on horizontal bed }
\end{aligned}
$$

The flattest side slope, $1 \mathrm{~V}: 4 \mathrm{H}$, and the horizontal test yield essentially the same critical velocity and will be used for $v_{c}$ in this analysis. The tractive force ratio $\mathrm{K}$ from Equation 4.23 is plotted against the side slope angle $\theta$ in Figure 4.19. Also shown in this figure is the analysis of Carter, Carlson, and Lane (1953) using an angle of repose of $40 \mathrm{deg}$ (OCE 1970). The Carter, Carlson, and Lane method shows a greater decrease in stability than the experimental data. The experimental results are consistent with the findings of Hughes, Urbonas, and Stevens (1983) stating that "rock size does not need to be 


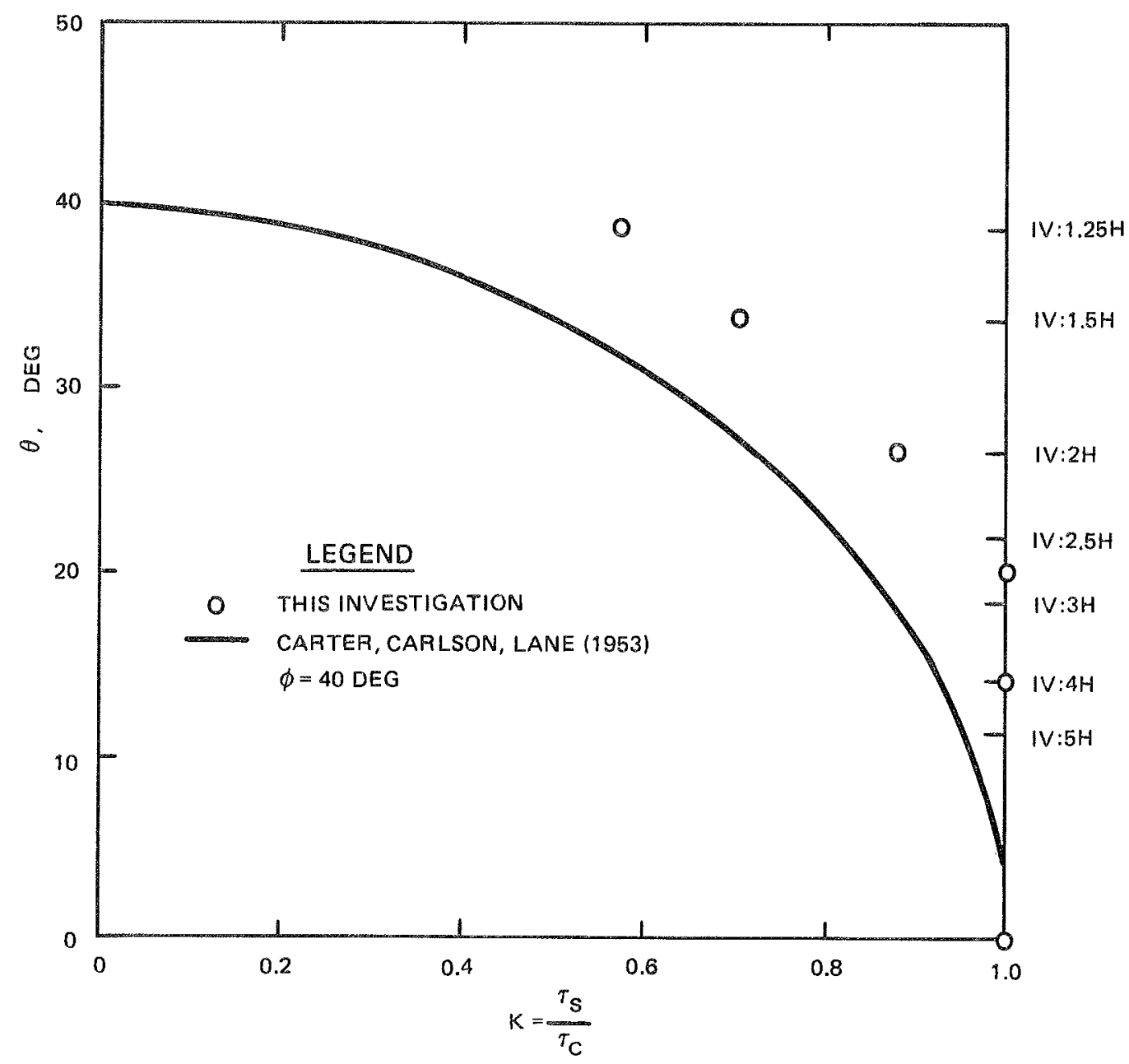

Figure 4.19. Tractive force ratio $K$ versus side slope angle $\theta$ (Data from Table 4.13)

increased for steeper channel side slopes, provided the side slopes are no steeper than $2 \mathrm{H}: 1 \mathrm{~V}{ }^{\text {"日 }}$

Tests were conducted to see if the assumed angle of repose of 40 deg was correct for the revetment used in these stability tests. The question arises, "Is the angle of repose of a revetment of varying height and thickness the same as the bulk angle of repose obtained from a pile of material?" The same revetment configuration used in the stability tests was placed on the hinged sloping side. The side slope angle was gradually increased until the revetment failed by sliding down 
the slope. The average value of repose angle obtained for this revetment configuration under dry conditions was 52 deg (see Table 4.14). These tests were repeated with the test section submerged, and the average repose angle was 53 deg. A third series of rests was conducted using pressure fluctuations to simulate the turbulent fluctuations that occur when water flows over the riprap. A pressure transducer was installed flush with the sloping side on which the riprap was placed. Measurements of pressure were taken for flow conditions close to the conditions that resulted in failure of the riprap. With the test section submerged but without flow, a variable speed vibrator was attached to the flume sidewal1. The speed of the vibrator was varled until the amplitude of the measured fluctuation was approximately equal to the maximum amplitude measured under zlowing water conditions. This vibrator speed was used in all subsequent angle of repose tests. The chird series with pressure fluctuations resulted in an average repose angle of 53 deg. The vibrator resulted in higher frequency fluctuations than did the flowing water condition but the amplitudes were similar. The predictive technique of Carter, Carlson, and Lane (1953) was again tested against the experimental data using the measured angle of repose of 53 deg. Results given In Flgure 4.20 show a much better com parison between predicted and observed values when the repose angle of 53 deg is used in the Carter, Carlson, and Lane equation, Equation 2.16. Additional tests were conducted to determine why the measured repose angle was significantly higher than that predicted by existing techiques (Anderson, Paintal, and Davenport 1970). These cests were conducted to determine the effects of reverment helght, bank smoothness, and revetment thickness. Results shom in Table 4.14 were plocted in 


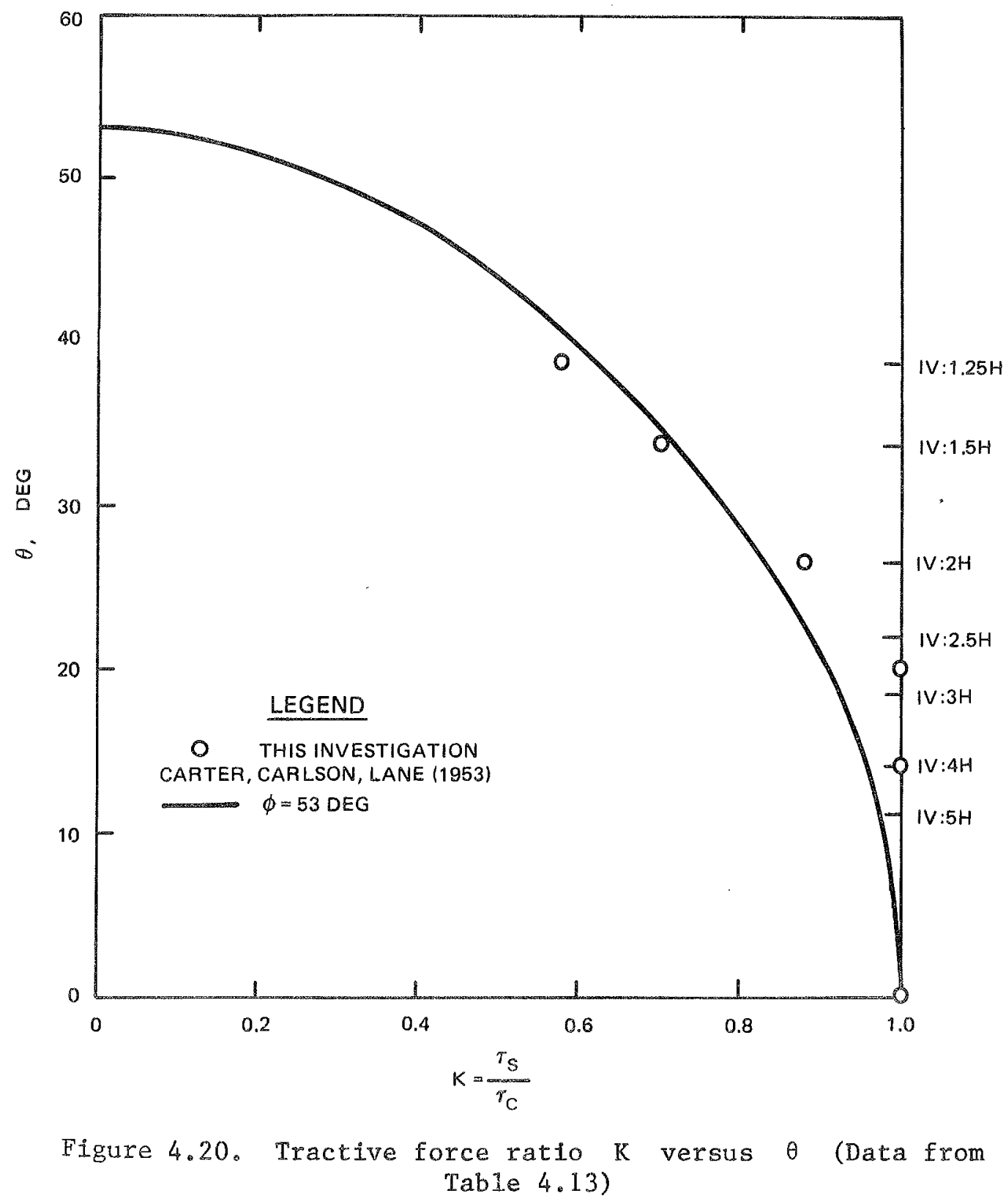

Figure 4.21. The relative height of the revetment is defined as the length along the slope $L_{s}$ divided by the average riprap size $d_{50}$. Revetment height $I_{s}$ was included to determine if a 50-ft-high channel bank is less stable or has a different angle of repose than a 10-ftanigh channel bank. Also shown on Figure 4.21 a is the repose angle for crushed rock from Anderson, Paintal, and Davenport (1970). These results show that revetment height and thickness have a significant effeci on 


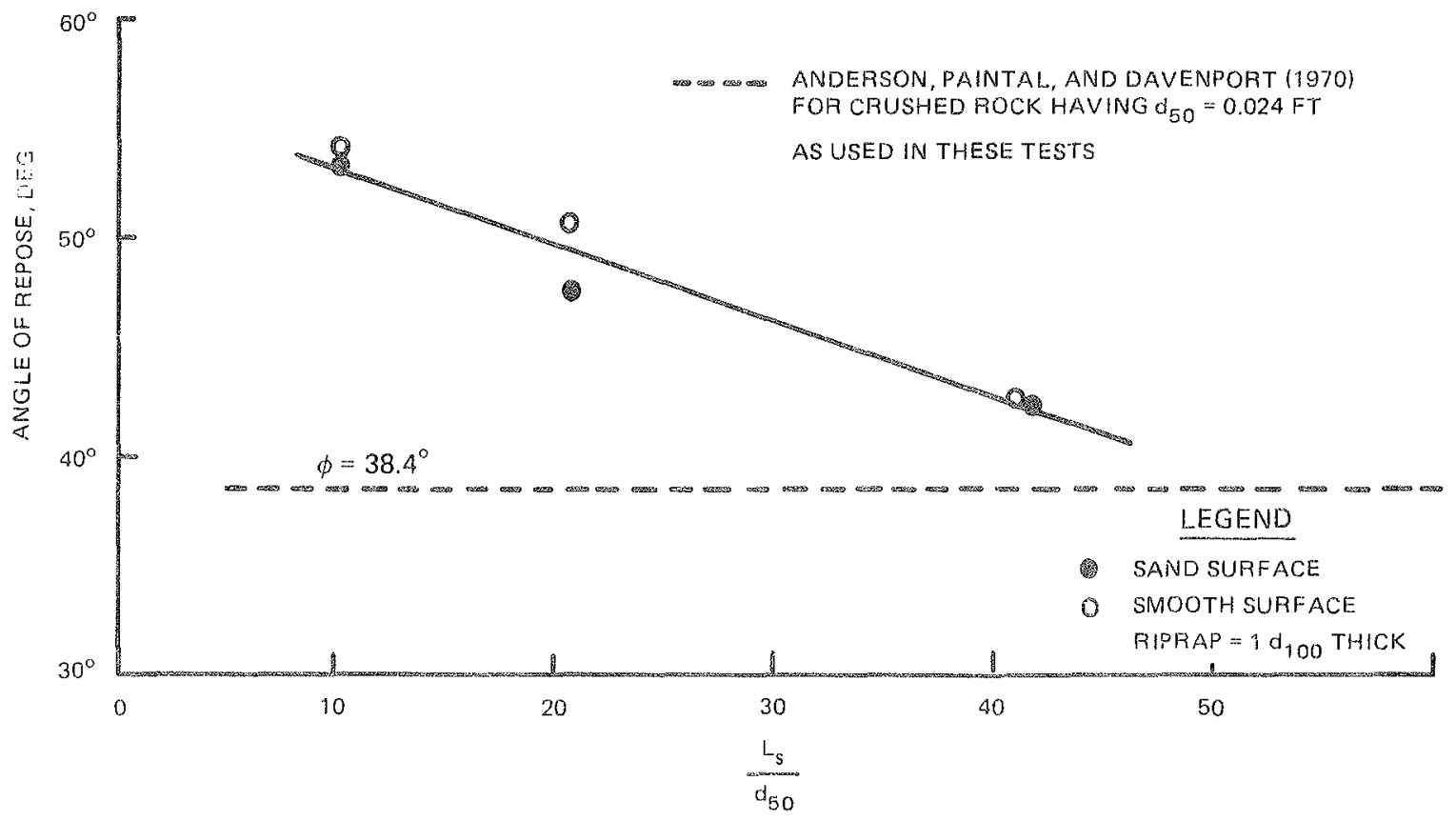

a. Angle of repose versus reverment height

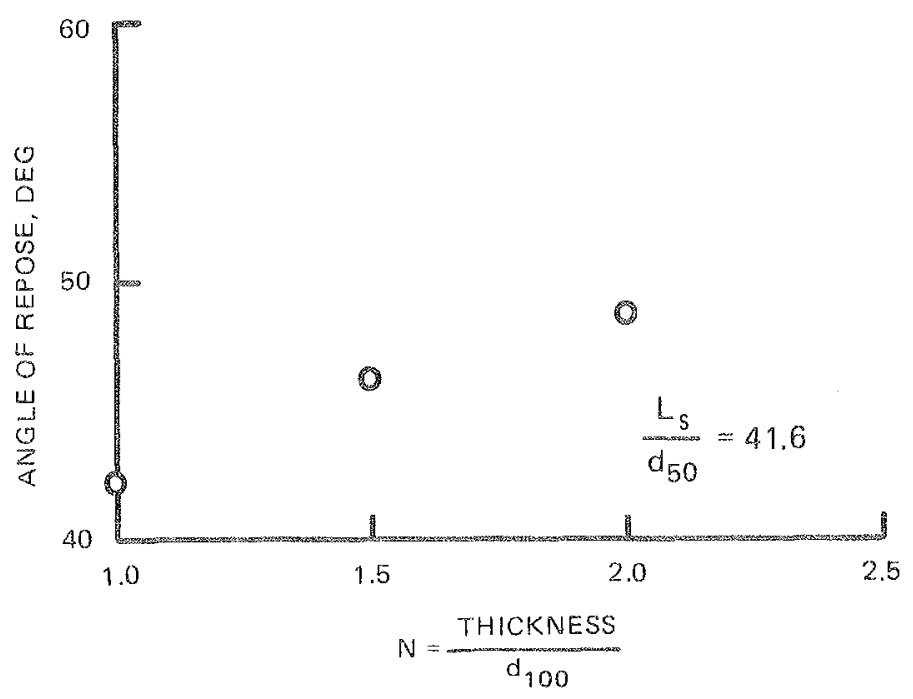

b. Angle of repose versus riprap thickness

Figure 4.21. Angle of repose of a revetment 
the angle of repose. Surface smoothness was tested by comparing the repose angle for a smooth piece of marine plywood to that of a surface having sand glued to the marine plywood. The smooth surface yields a slightly higher value than the sand surface. The difference is sma11 and surface roughness is not considered to be a big factor in angle of repose for the two surfaces used in these tests.

The California Division of Highways (1970) uses a repose angle of $70 \mathrm{deg}$ in the predictive equations. Blodgett and McConaughy (1986) report that this was based on tests in which

They constructed a model streambank on which small stones were arranged as riprap, and underlying stones were cemented in a plaster of paris base. The side slope was increased until the first outer stone was displaced. It was determined that $65^{\circ}$ to $70^{\circ}$ was the maximum angle attained before a stone fe11 out.

Miller and Byrne (1965) found the angle of repose of a single sand grain on a fixed rough bed to be as high as 70 deg when the fixed rough bed particles were equal in size to the single sand grain. Both the California study and M1ller and Byrne show that surface roughness becomes important when the underlying material size becomes large relam tive to the size of the riprap. Hudson (1958) did not include the coefficient of friction (angle of repose) in the development of his widely used equations for the design of quarrystone cover layers subjected to wave attack. He cited several factors that presented dfficulty in. using angle of repose. Method of placement was one of the factors that caused variation in the repose angle.

The following results summarize angle of repose:

1. The angle of repose of a revetment is not always equal to the bulk angle of repose reported in the literature. 
2. The angle of repose of a revetment is affected by revetment height, thickness, method of placement, and possibly other factors that were not investigated.

Similar to Hudson (1958), this investigation will omit repose angle from the analysis of side slope stability and incorporate repose angle effects into the empirically derived coefficients.

4.4.2 Velocity Profiles Over Channel Side Slopes. As part of the CSU Phase IV riprap stability tests, velocities were measured over the IV:2H side slope in a straight flume. Results from tests having similar depth were averaged. Velocities were made dimensionless by dividing observed point velocity by the average velocity of a single vertical traverse over the toe of the slope, and depths were expressed in percentage of the total depth. Results shown in Figure 4.22 indicate reduced velocities over the slope and that the influence of the slope extends out from the toe of the slope approxtmately 0.5 times the depth of flow. The measured depth at the toe of the slope was generally 95 pexcent of the depth in the horizontal portion of the channe1. This is shown in Figure 4.22 where the cross section is rounded at the toe of the slope. These profiles are for straight channels without the effects of upstream channel curvature. An analysis of the shear distribution of the profiles was conducted using the approach given in Section 4.4 .1 . The shear stress was evaluated relative to the shear stress in the horim zonta1 portion of the cross section at $X / D=-1,0$. The velocity along the channel bottom was determined at a distance of 0.10 above the bed, 


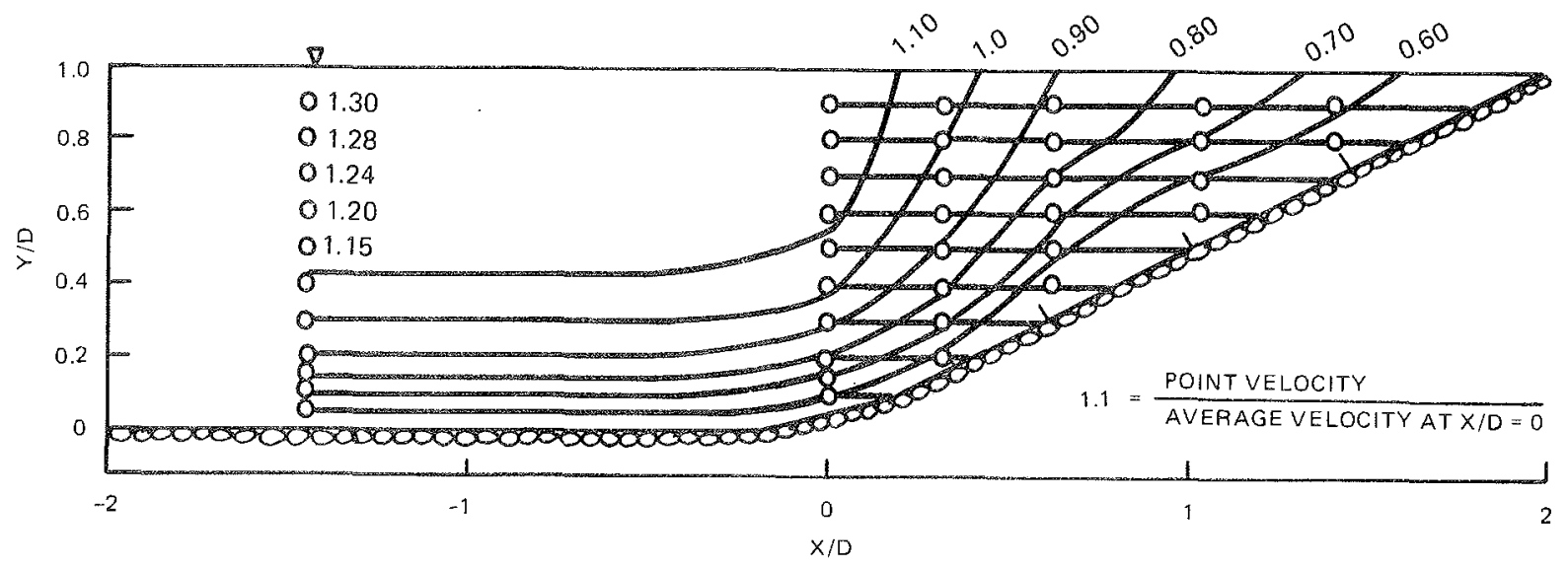

Tests 21,22 , and $23, \mathrm{~d}_{50}=1 \mathrm{in}$, thickness $=2 \mathrm{in}$.

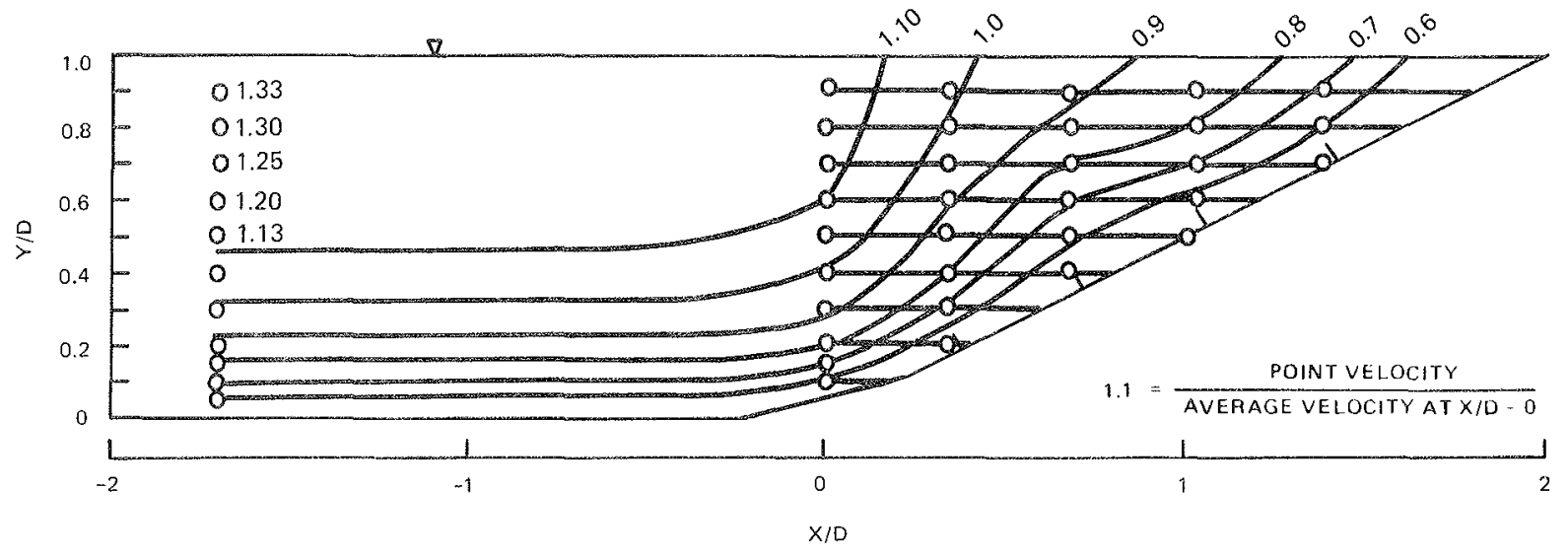

Tests 16 and $18, \mathrm{~d}_{50}=1 \mathrm{in}$, thickness $=2 \mathrm{in}$.

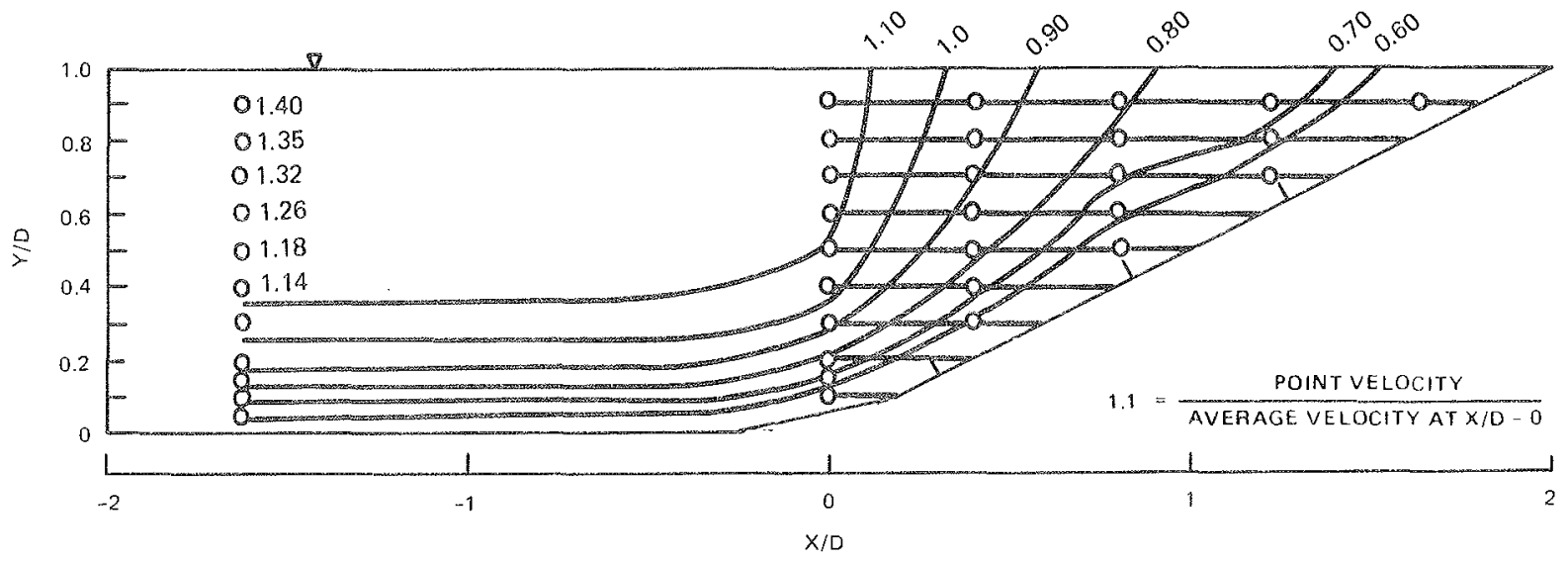

Tests $42,43,44 d_{50}=1$ in。, thickness $=1.5 \mathrm{in}$.

Figure 4.22. Velocity profiles, CSU Phase IV side slope tests 
where $D$ is the depth at $X / D=1.0$. The relative shear is deternined from

$$
\frac{T}{T \text { at } \frac{X}{D}=-1.0}=\frac{V^{2}}{V^{2} \text { at } \frac{X}{D}=-1.0}
$$

Restlts from the three profiles, plotted in Igure 4.23 , show that the shear stress is less on the channel side slope than on the channel botton.

Another series of veloctty measurements was conducted in a curved channel at WES to determine velocity profiles over slde slopes that have strong upstream curvature effects. Profiles were measured at statons $11.6,16.6,21.6,65.0,70.0$, and 75.0 , shown in Figure 4.24 . These stations correspond to the regions of maximum velocity over the toe of the slope. Nondimensional profiles were derermined (Figures 4.25 and 4.26 ) and are significantly different fxom the profiles having a straight upstream alignment. These curved channel profiles show a velocity maximum over the toe of the slope, with the naximum located below the water surface.

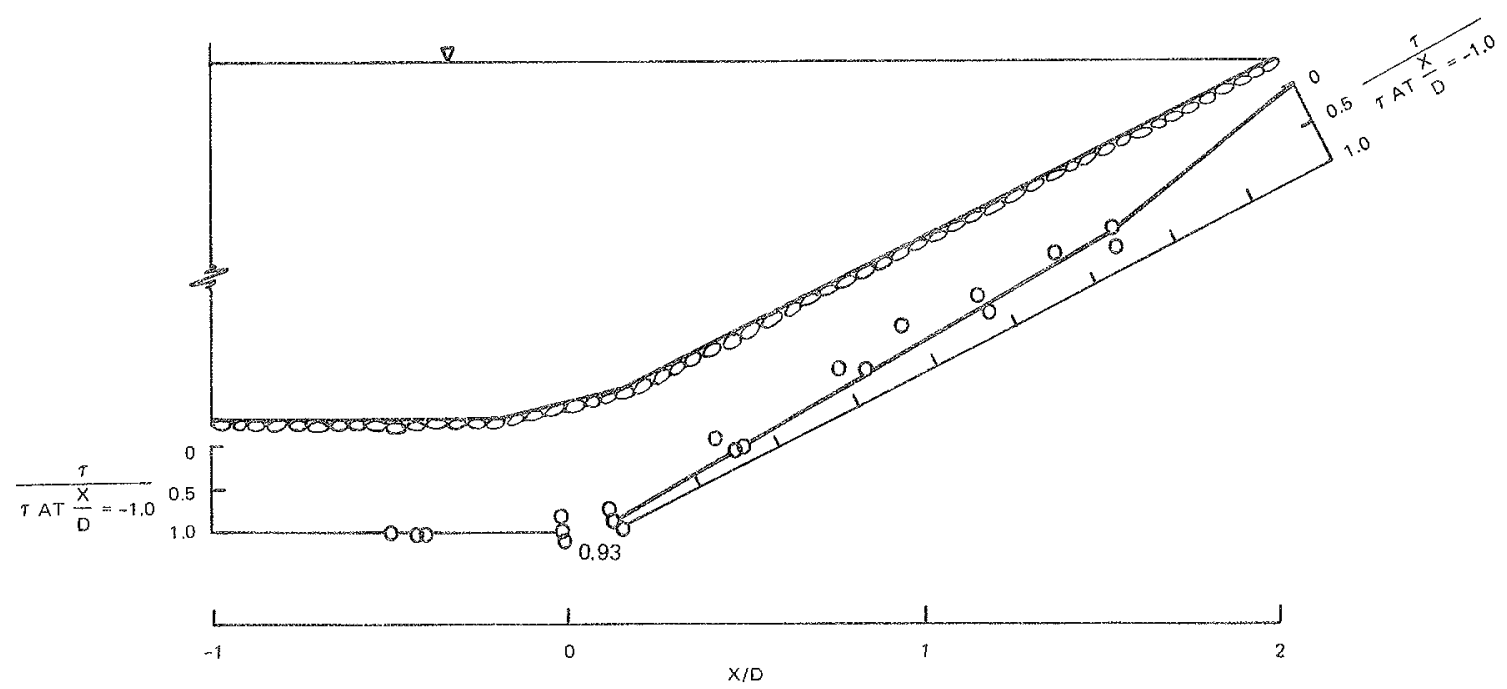

Figure 4.23. Shear stress distribution, $1 \mathrm{~V}: 2 \mathrm{H}$ side slope, straght channe1. 


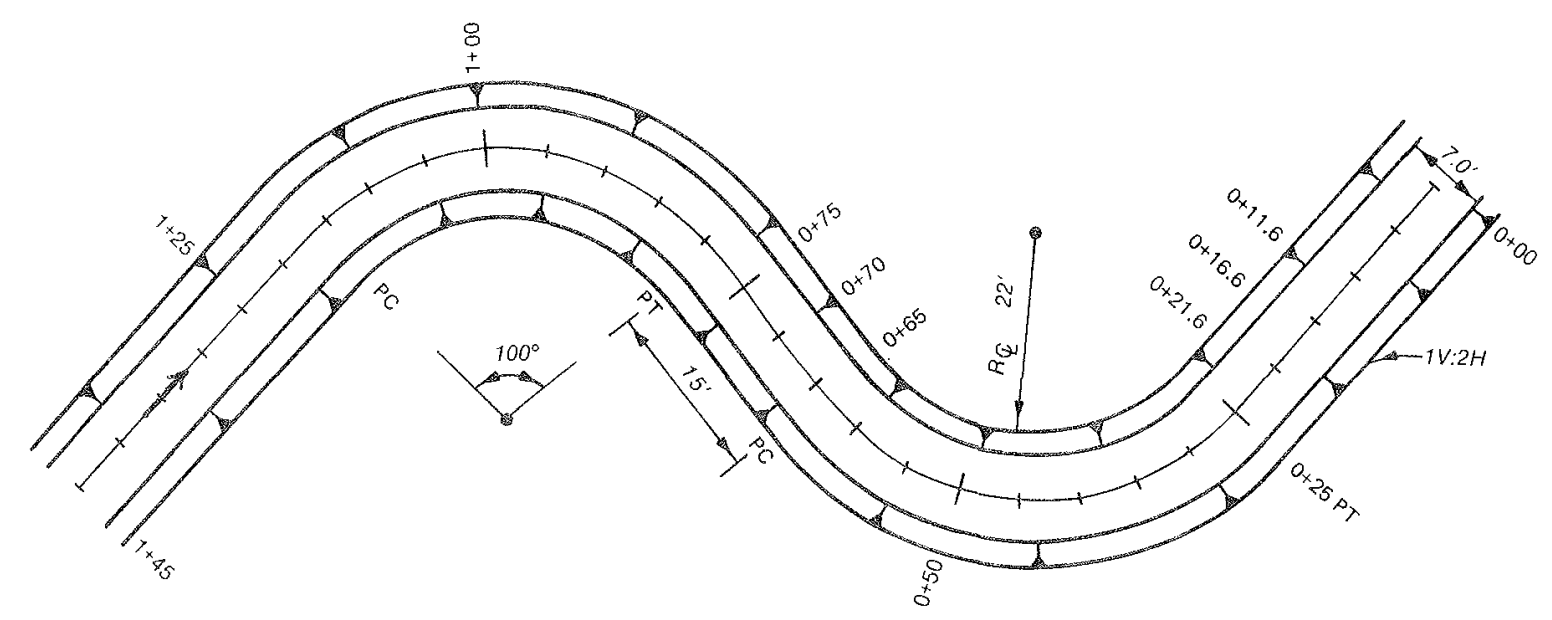

Figure 4.24. WES curved channe1 model, plan view An analysis of the shear in the straight versus curved section was conducted using the same analysis used in Equation 4.24. For equal average velocity over the toe of the slope, the maximum stress on the curved channel side slope (located at $X / D=0.5$ ) is equal to approximately 1.5 times the sheax stress at $X / D=0.5$ in the straight channe 1 side slope.

\subsubsection{Side Slope Stability Tests. Before side slope stability} tests are analyzed, a characteristic velocity and depth must be selected. This velocity and depth must be representative of the condithons on the side slope and must also be values which a designer has some hope of determining or estimating. Average channel velocity is the eastest to detemine but not very representative of conditions on the side slope. Depth and average velocity over the toe of the slope will be used in this investigation for the side slope stability analysis. These values were selected based on the two requirements stated prem viously and the results from the WES curved channel, which showed that 


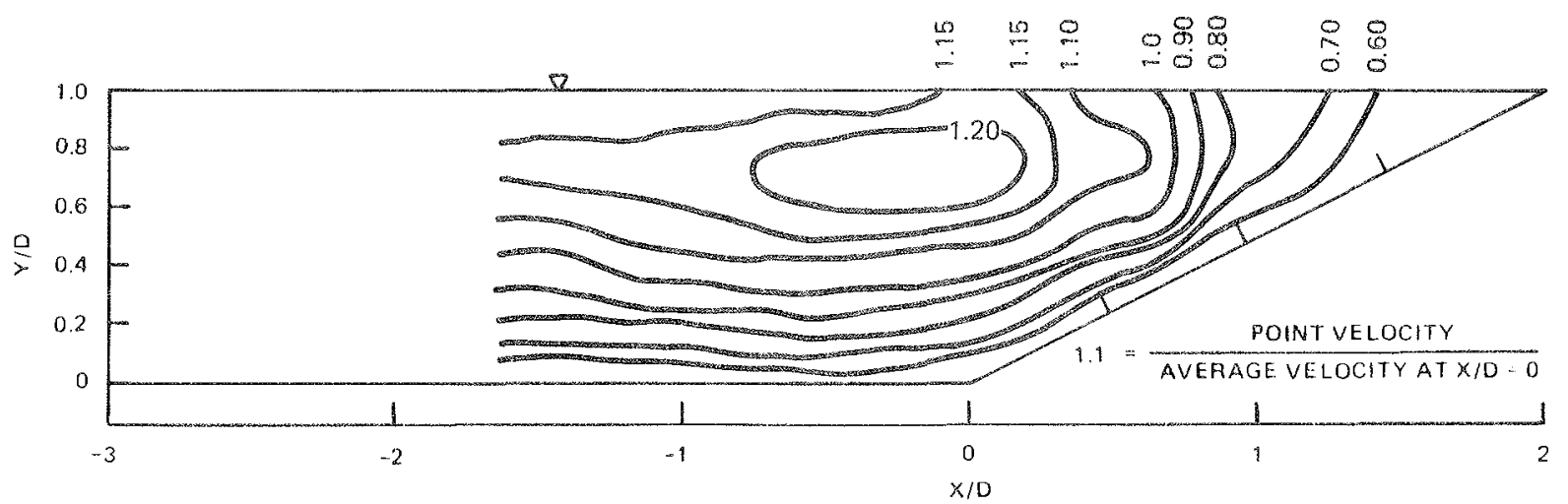

a. Station 11.6

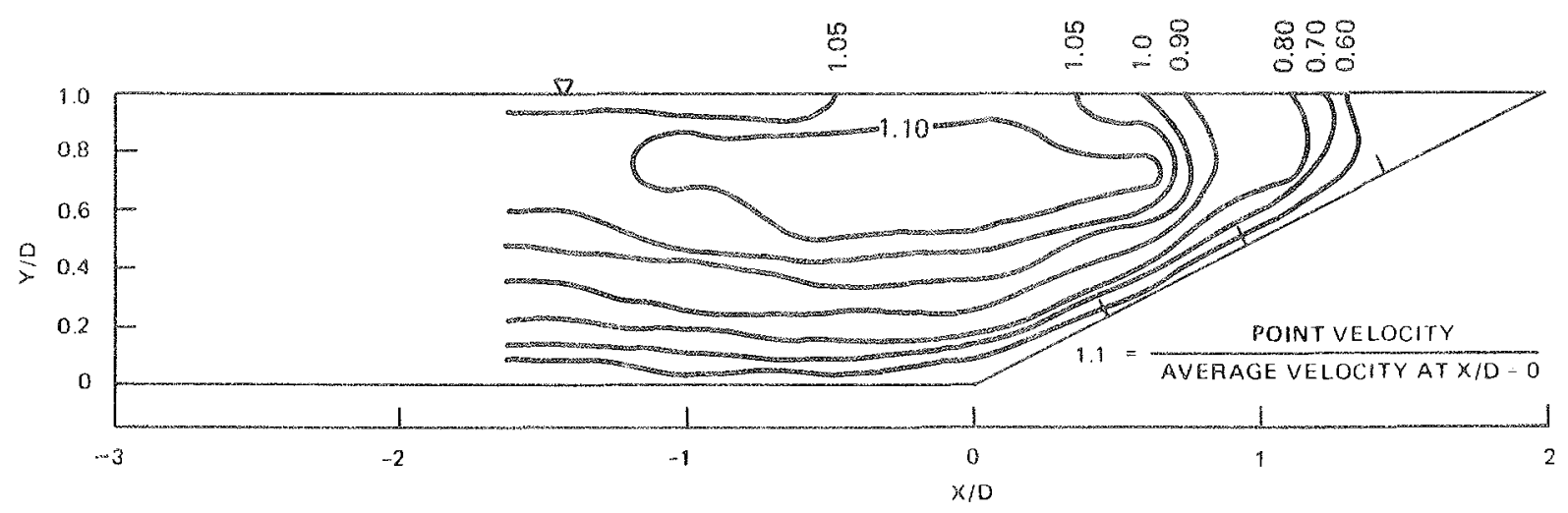

b. Station 16.6

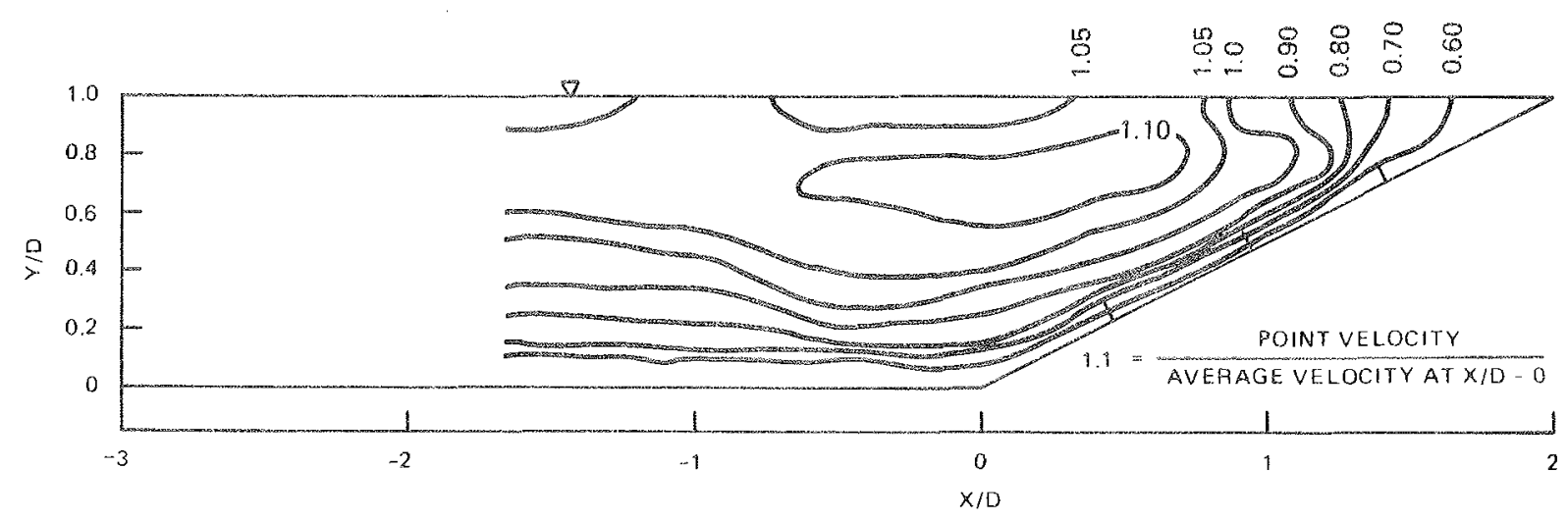

c. Station 21.6

Figure 4.25. Velocity profiles, WEs curved channel facility, stations $11.6,16.6$, and 21.6 


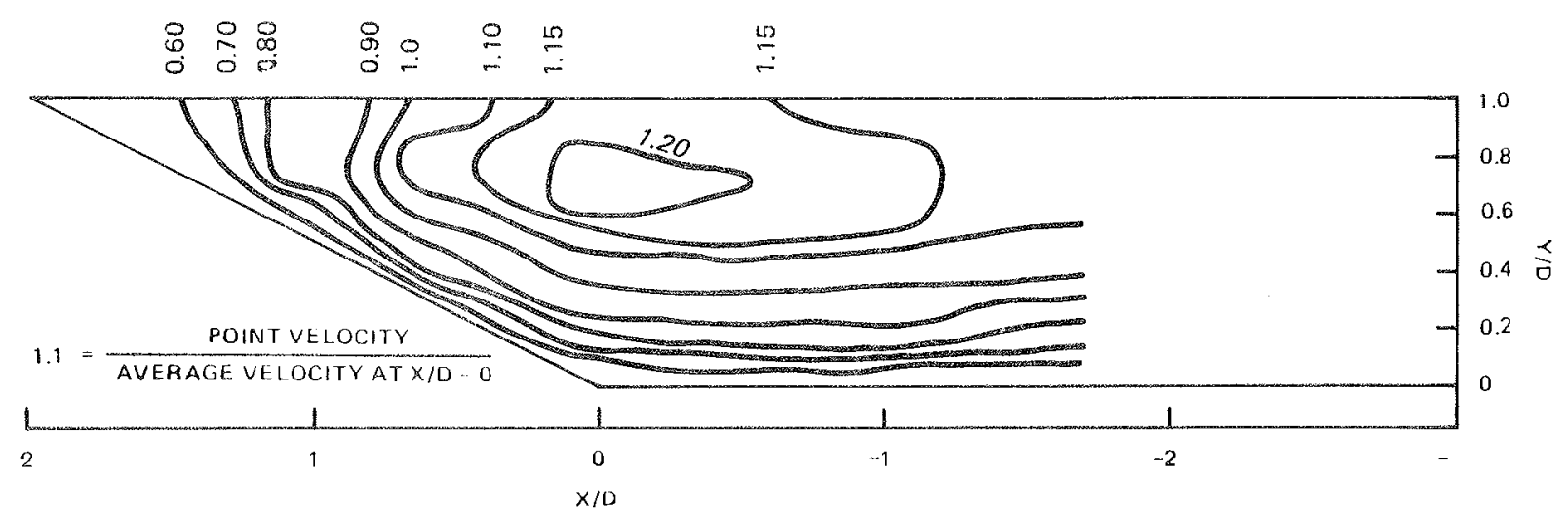

a. Station 65

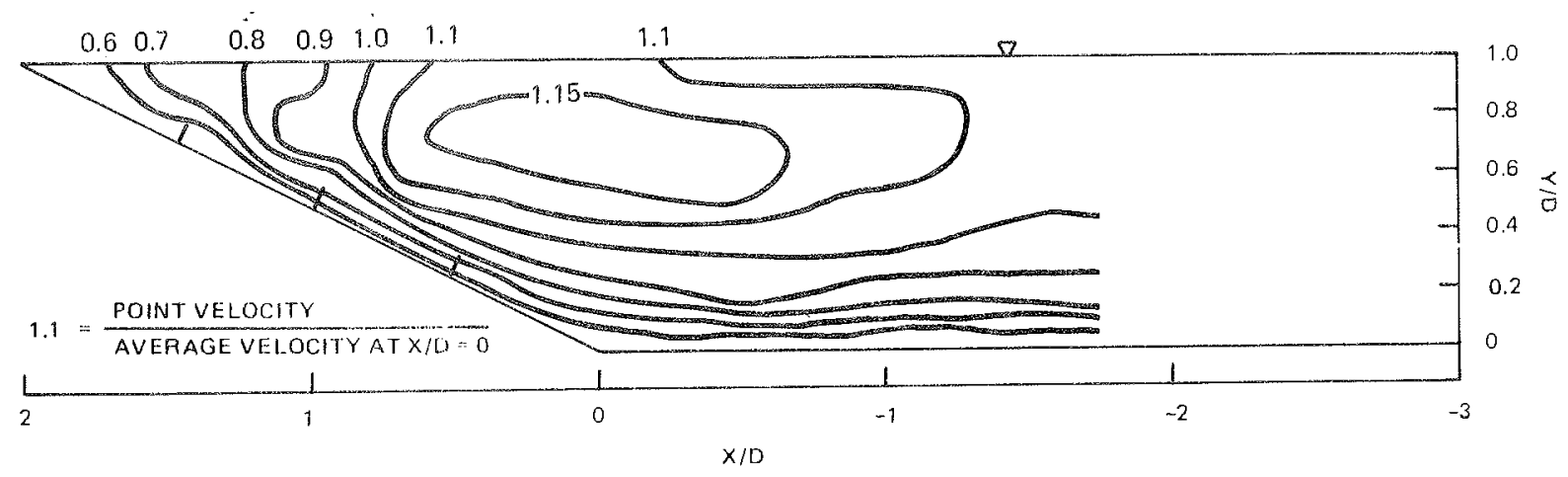

b. Station 70

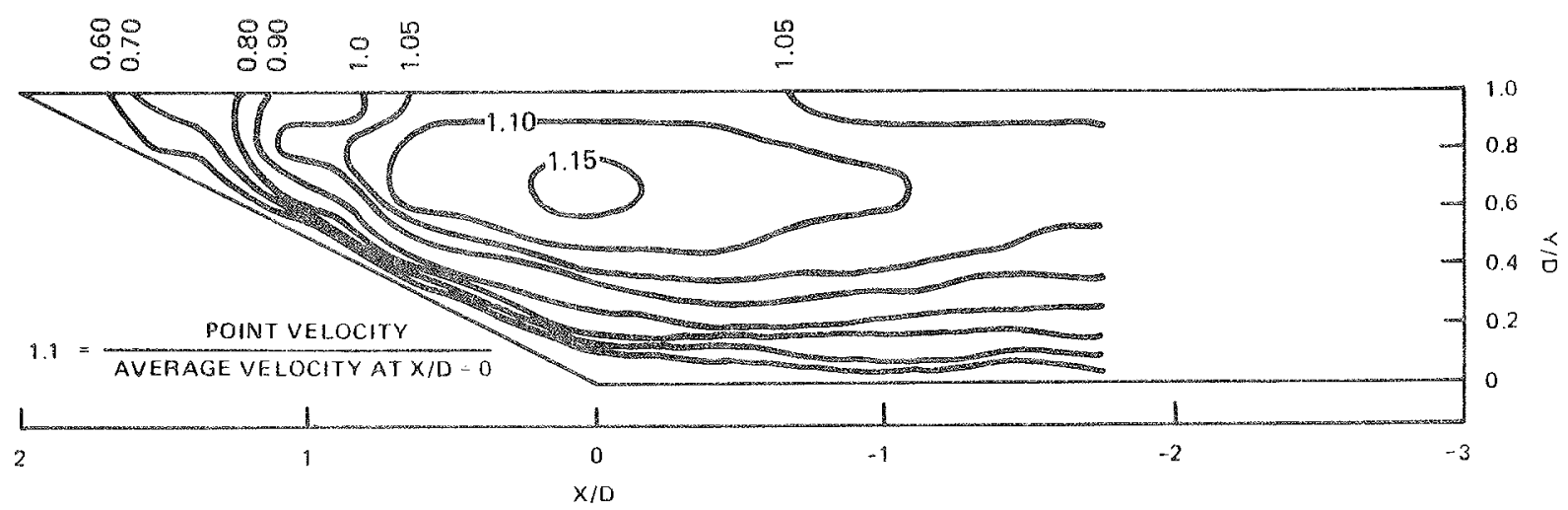

c. Station 75

Figure 4.26. Velocity profiles, WES curved channel facility, stations 65,70 , and 75 
the maximum veloctey in the cross section occurred over the toe of the side slope。

Prior to the CSU Phase IV side slope stability tests, an analysis was conducted of the Dorena Dam prototype tests reported by the US Army Engineer District, Portland (1952). These tests were conducted downstream of Dorena Dam in a channel having a grouted xiprap boctom and IV: $2 \mathrm{H}$ side slopes with riprap placed to a thickness of $1 \mathrm{~d}_{100}$. Results are shown in Table 4.15 and Figure 4.27. The curve for threshold of incipient failure, thickness of $1 \mathrm{~d}_{100}, 1 \mathrm{~V}: 2 \mathrm{H}$ side slope, and straight channe1. is

$$
\frac{d_{30}}{D}=0.23\left[\left(\frac{\gamma_{W}}{\gamma_{S}-\gamma_{W}}\right)^{1 / 2} \frac{\mathrm{V}}{\sqrt{g D}}\right]^{2.5}
$$

based on the Dorena Dam prototype tests. The depth and velocity over the toe of the slope were used in the analysis. The velocities were measured for several tests, and these were used to estimate the velocity in the remaining tests.

In the CSU Phase IV tests, stability was determined for the following:

\begin{tabular}{lcr}
$\begin{array}{ccc}\mathrm{d}_{50} \\
\text { in. }\end{array}$ & $\frac{\text { Thi.ckness }}{\mathrm{d}_{100}}$ & Table \\
\hline 1.0 & 1.33 & 4.16 \\
1.0 & 1.0 & 4.17 \\
0.5 & 1.0 & 4.18
\end{tabular}

Like the Dorena Dam tests, these tests were conducted in a stralght channel without upstrean curvature effects.

The results given in Tables $4.16 \mathrm{~m} 4.18$ show that the bottom riprap fails more often or with greater severfty than the side slope riprap. 


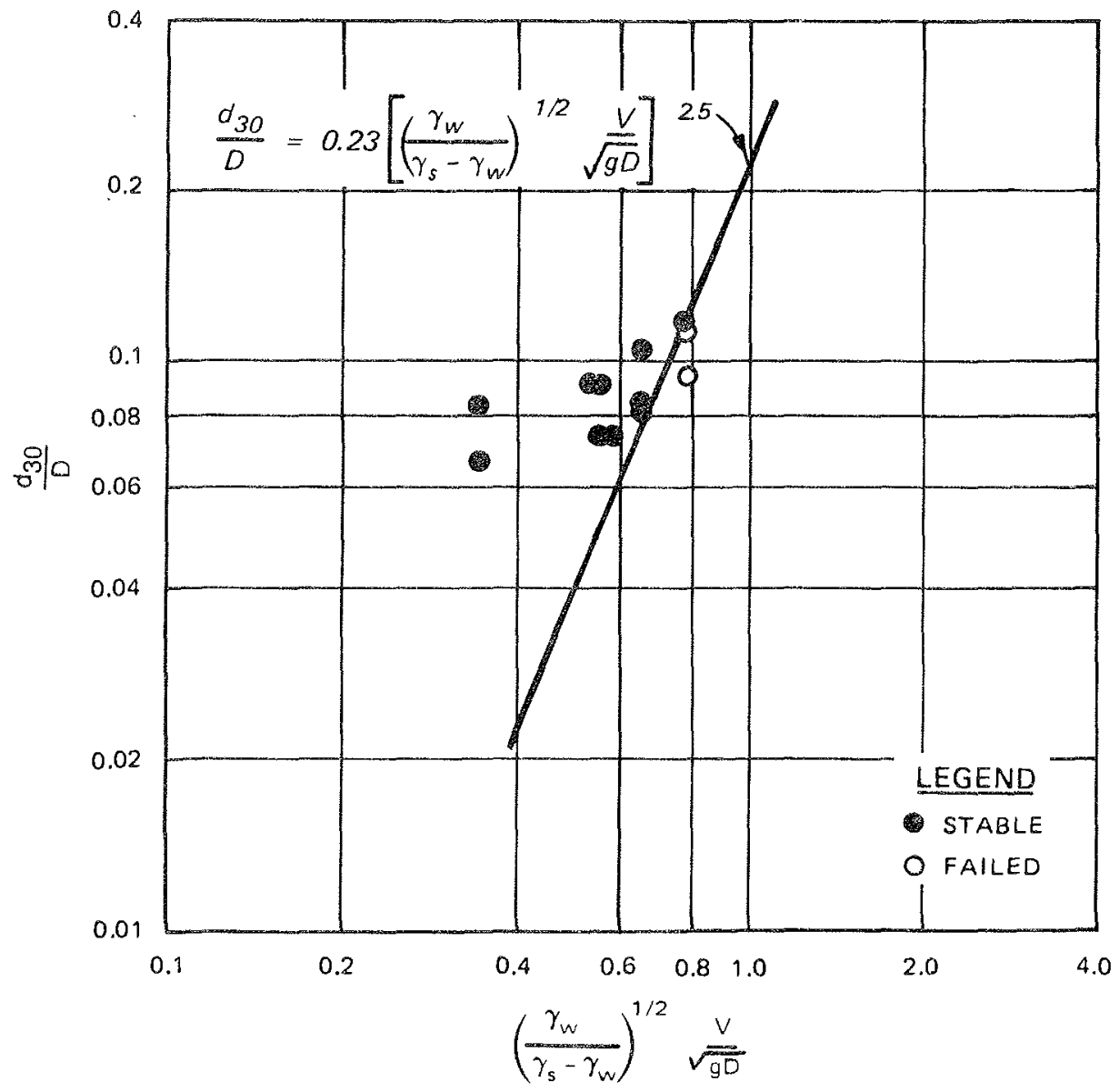

Figure 4.27. $\mathrm{d}_{30} / \mathrm{D}$ versus modified Froude number, thickness of $1.0 \mathrm{~d}_{100}, 1 \mathrm{~V}: 2 \mathrm{H}$ side slope, Dorena Dam prototype tests (Data
from Table 4.15 )

In tests 29-35 (Table 4.16) with the 1-in. $d_{50}$ riprap placed 2 in. thick, the bed was stabilized with a wire screen to ensure failure on the side slopes. Results from tests with a thickness of $1 d_{100}$ are shown in Figure 4.28. A failure point from test 21 is located to the left of the incipient failure line. This test had a total failed area of less than $0.1 \mathrm{sq} \mathrm{ft}$. Due to the small failure area and the position of this point relative to several stable runs, this point was not used in the determination of the best-fit line. The curve for threshold of 


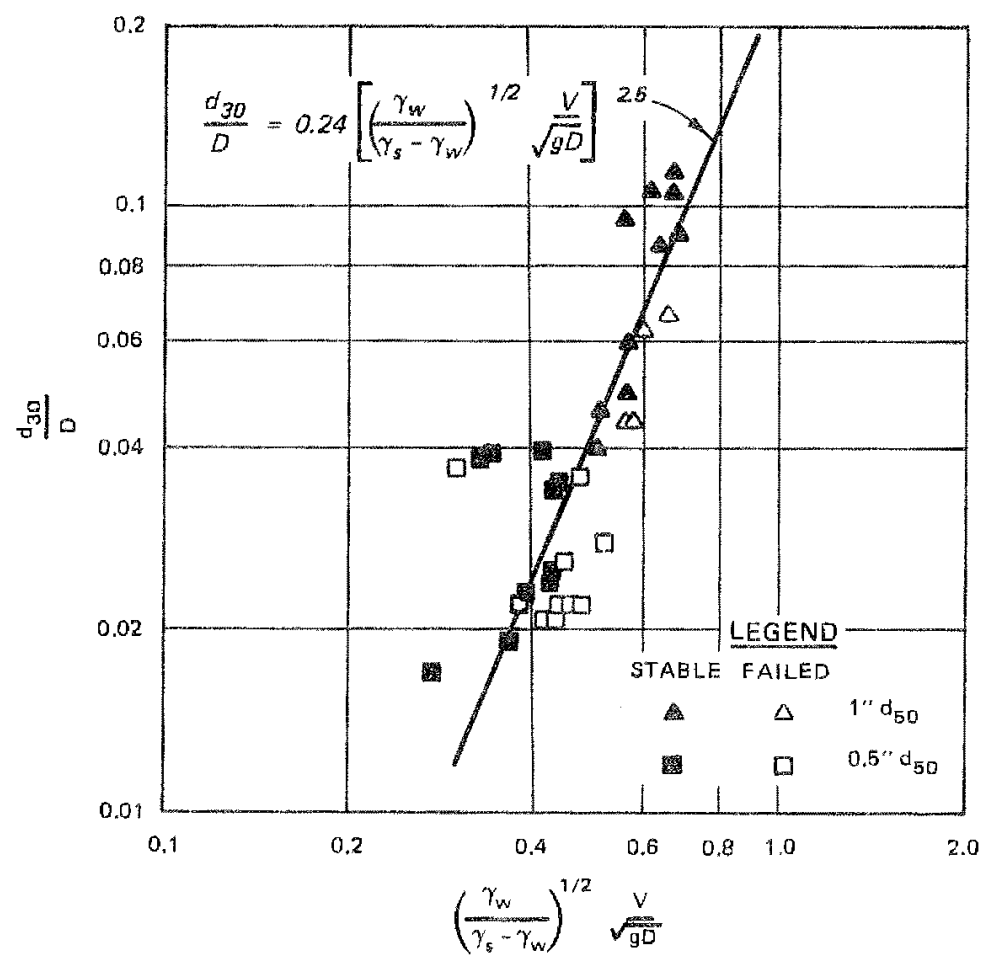

Figure 4.28. $d_{30} / D$ versus modified Froude number, thickness of Id 100 , IV:2H side slope, CSU Phase IV (Data from Tables 4.17 and 4.18 )

incipient fallure, a thickness of $1 \mathrm{~d}_{100}, 1 \mathrm{~V}: 2 \mathrm{H}$ side slope, and straight channel is

$$
\frac{\mathrm{d}_{30}}{\mathrm{D}}=0.24\left[\left(\frac{\gamma_{\mathrm{w}}}{\gamma_{\mathrm{s}}-\gamma_{\mathrm{w}}}\right)^{1 / 2} \frac{\mathrm{v}}{\sqrt{\mathrm{gD}}}\right]^{2.5}
$$

based on the CSU Phase IV tests. This relation is in close agreement with the Dorena Dam prototype test results.

Results from the CSU tests with a thickness of $1.33 d_{100}$ are shown In Figure 4.29. The effects of thickness for side slope riprap are

$$
\frac{C_{12}(N=1.33)}{C_{13}(N=1.00)}=\frac{0.19}{0.24}=0.79
$$




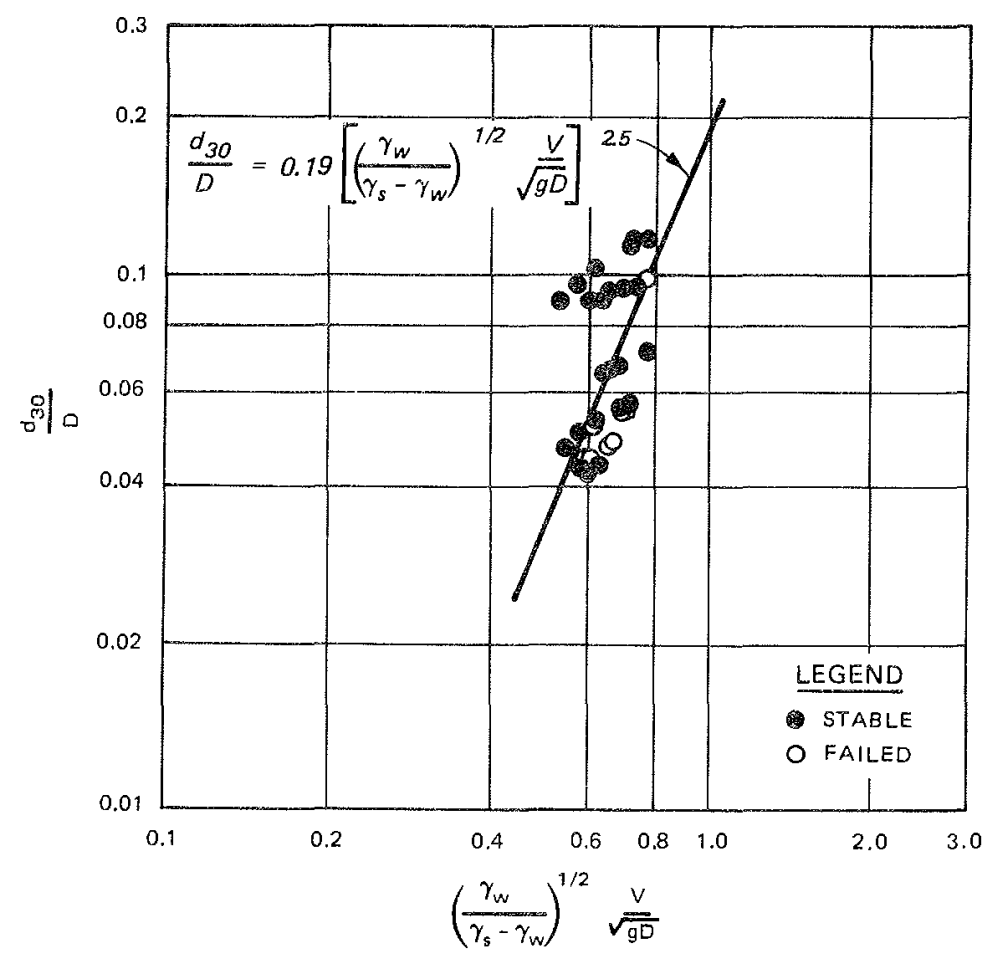

Figure 4.29. $d_{30} / D$ versus modified Froude number, a thickness of $1.33 \mathrm{~d}_{100}, 1 \mathrm{~V}: 2 \mathrm{H}$ side slope, CSU

Phase IV (Data from Table 4.16)

From Figure 4.15 the effect of thickness for bottom riprap is

$$
\frac{C_{14}(N=1.33)}{C_{15}(N=1.00)}=\frac{0.225}{0.30}=0.75
$$

which is essentially the same thickness effect as the side slope riprap. Note that these thickness results apply only to gradations having a $\mathrm{d}_{85} / \mathrm{d}_{15}$ ratio of $2-2.3$.

A Iimited series of stability tests was conducted in the WES curved channel facility shown in Figure 4.24. These tests were limited in the sense that only a narrow range of rock size could be failed while maintaining a high enough Reynolds number based on the limitations given in section 3.5. Results are shown in Table 4.19 and Figure 4.30. With so few data points, the basic relation given by Equation 4.21 is used to define the slope of the power function. The relation describing the 


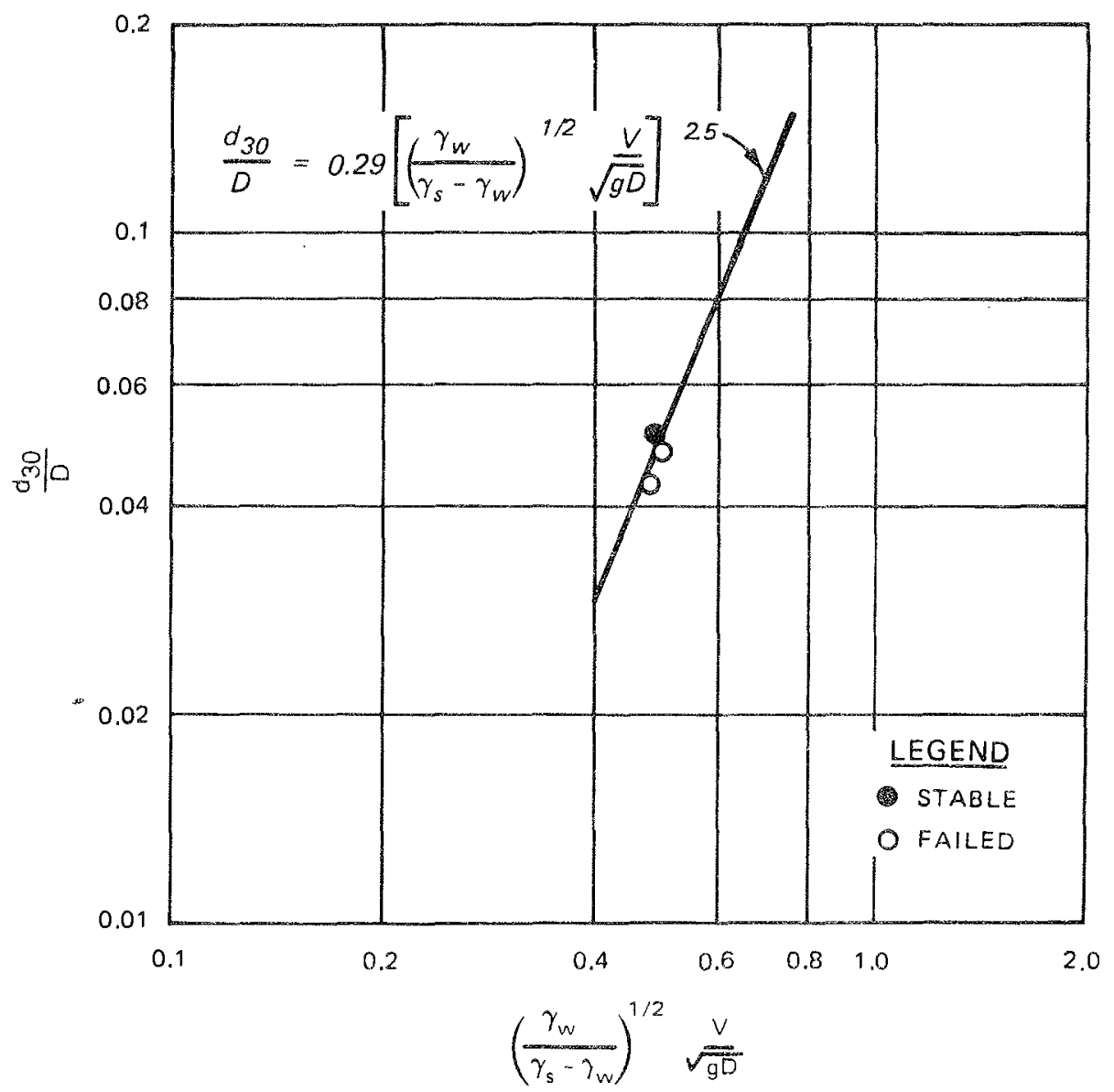

Figure 4.30. $\mathrm{d}_{30} / \mathrm{D}$ versus nodified Froude number, thickness of $1 \mathrm{~d}_{100}, 1 \mathrm{~V}: 2 \mathrm{H}$ side slope, WES curved channel (Daca from Table 4.19)

threshold incipient failure for a thickness of $1 \mathrm{~d}_{100}, 1 \mathrm{~V}: 2 \mathrm{H}$ side slope, and curved channel is

$$
\frac{\mathrm{d}_{30}}{\mathrm{D}}=0.29\left[\left(\frac{\gamma_{\mathrm{w}}}{\gamma_{\mathrm{s}}-\gamma_{\mathrm{w}}}\right)^{1 / 2} \frac{\mathrm{v}}{\sqrt{\mathrm{gD}}}\right]^{2.5}
$$

based on the WES curved channel model using depth and average velocity over the toe of the side slope.

This model derived relationship can be compared to the prototype data of Blodgett and McConaughy (1986). These data were taken mainly from curved channels. Since side slope angle is generally considered to 
be significant, only sites with the cotangent of the side slope angle between 1.8 and 2.2 were used in this analysis. To best estimate the average velocity and depth over the toe of the slope, the maximum depth and maximum velocity were used in the analysis. In cases where the maximum velocity was not measured, the relation

$$
\mathrm{V}_{\max }=1.53 \mathrm{~V}_{\text {avg }}
$$

was derived from the Blodgett and McConaughy data and used to estimate maximum velocity. A similar approach was used to estimate $d_{30}$ for measurements where sufficient data were not given. The values used in the analysts are shown in Table 4.20 and Figure 4.31. Only sites with particle erosion or no damage were considered in the analysis. Blanket thicknesses are not given, and these results are considered applicable to a thickness of $1 \mathrm{~d}_{100}$ since most prototype sites are constructed to this thickness. The incipient failure curve shown in Figure 4.31 is drawn to the right of two failure points (measurements 6 and 7 ). The site of these measurements was a channel curved only $18 \mathrm{deg}$. The failure for measurement 6 was on the upper $6 \mathrm{ft}$ of the channel side slope, which is unusual. Blodget and McConaughy state that the velocity for measurement 6 "may have been greater than estimated." The data for measurement 7 show a relatively low velocity but an extremely high shear stress. The high-water profile shows some unusual conditions such as an adverse water-surface slope over the point of failure. Considering these problems and the proximity of points 6 and 7 to other stable points, these failure points were not considered in the analysis. The resulting threshold of incipient failure curve for $1 \mathrm{~V}: 2 \mathrm{H}$ side slope, a thickness of $1 d_{100}$, and curved channels is the same as that proposed for bottom riprap or 


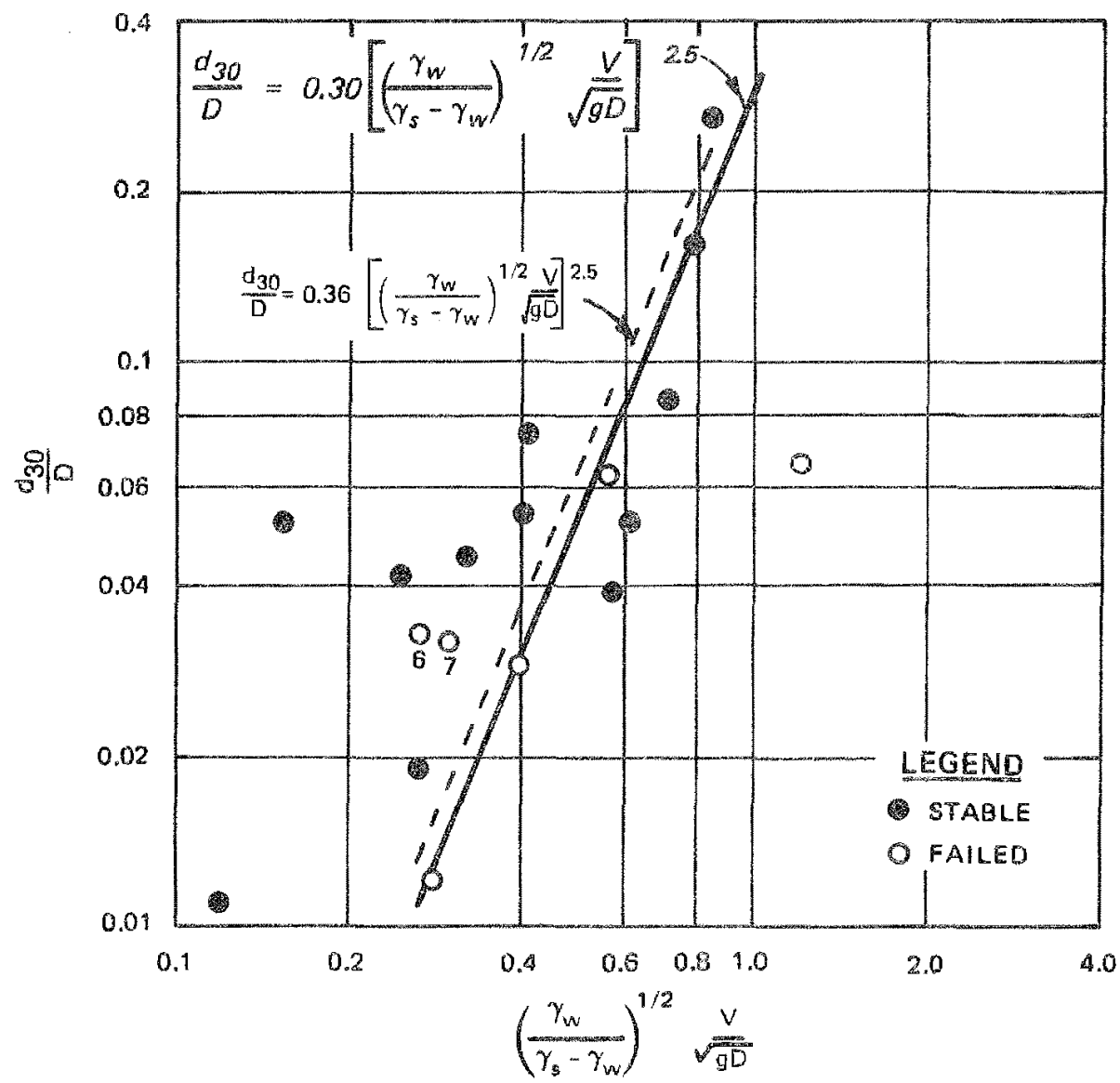

Figure 4.31. $\mathrm{d}_{30} / \mathrm{D}$ versus modified Froude number, thickness of $1 \mathrm{~d}_{100}, 1 \mathrm{~V}: 1.8 \mathrm{H}$ to $1 \mathrm{~V}: 2.2 \mathrm{H}$ slde slope, Blodgett and McConaughy (1986) prototype data (Data from Table 4.20)

$$
\frac{d_{30}}{D}=0.30\left[\left(\frac{Y_{W}}{Y_{S}-\gamma_{W}}\right)^{1 / 2} \frac{\mathrm{V}}{\sqrt{\mathrm{gD}}}\right]^{2.5}
$$

which is in close agreement with the model relation determined in the WES curved channel model. This relation uses the depth and average velocity over the toe of the side slope. 
CHAPTER 5

SAFETY FACTORS, SIZING NOMOGRAPH, AND DESIGN APPLICATION

\subsection{SAFETY FACTORS}

The threshold of incipient fallure for bottom riprap and $1 \mathrm{~V}: 2 \mathrm{H}$ side slope riprap in curved channels was shown to be described by

$$
\frac{d_{30}}{D}=0.30\left[\left(\frac{\gamma_{w}}{\gamma_{G}-\gamma_{w D}}\right)^{1 / 2} \frac{v}{\sqrt{g D}}\right]^{2.5}
$$

Until additional tests can be conducted to define the relationship for other side slopes, Equation 4.21 should be used for all slopes equal to or flatter than $1 \mathrm{~V}: 2 \mathrm{H}$. This relation is applicable to a thickness of ${ }^{1 d}{ }_{100}$, which is the most common thickness used in open channel riprap. Since this relation describes inclpient failure, a safecy factor must be used in design. A comron problem that should be avolded in design of riprap is the addition of safety factors at all steps in the design procedure. The use of available gradations often adds a safety factor to the design because the computed riprap size falls between two available gradations and the designer must choose the larger gradation. A safety factor of 1.2 times the $d_{30}$ riprap sjac given by Equacion 4.21 provides stability above the fallure polnts used the analysis of the Blodgett and McConaghy prototype data. Using this safery factox yields

$$
\frac{d_{30}}{D}=0.36\left[\left(\frac{\gamma_{W}}{\gamma_{\mathrm{S}}-\gamma_{\mathrm{W}}}\right)^{1 / 2} \frac{\mathrm{v}}{\sqrt{\mathrm{gD}}}\right)^{2.5}
$$

This equation is shown by the dashed line in Figure 4.31 . 


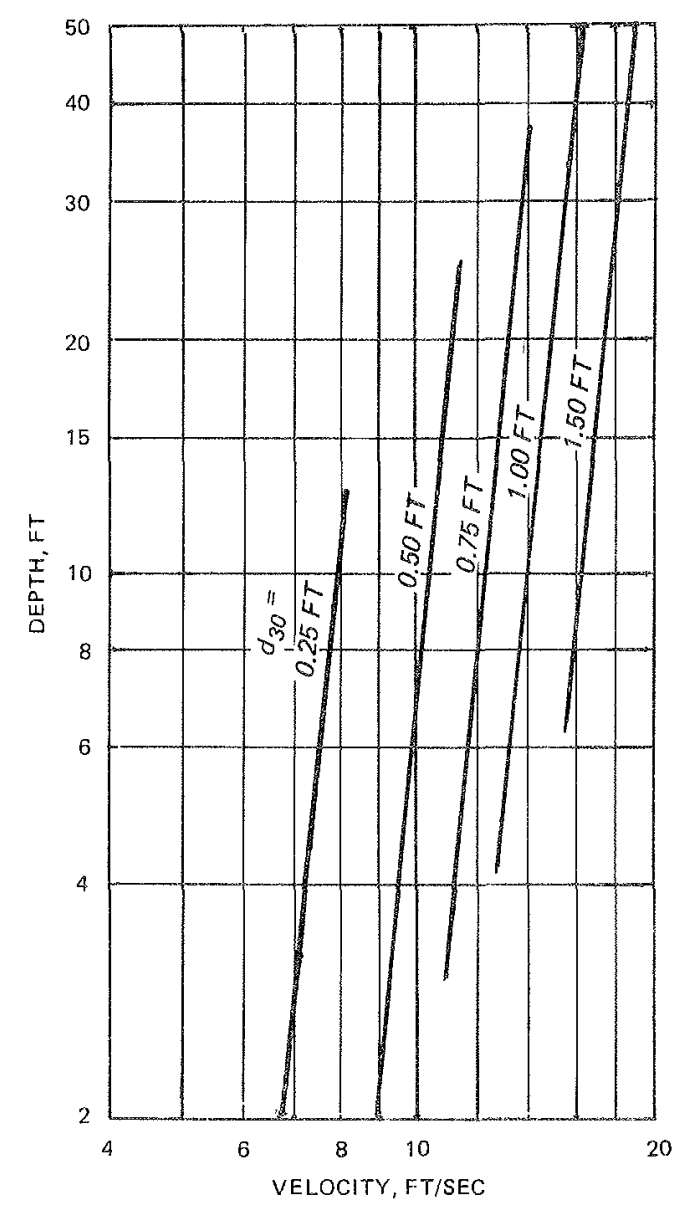

a. Velocity versus depth versus $d_{30}$ for unit stone weight $=$ 165 pcf, thickness $=1 \mathrm{~d}_{100}$

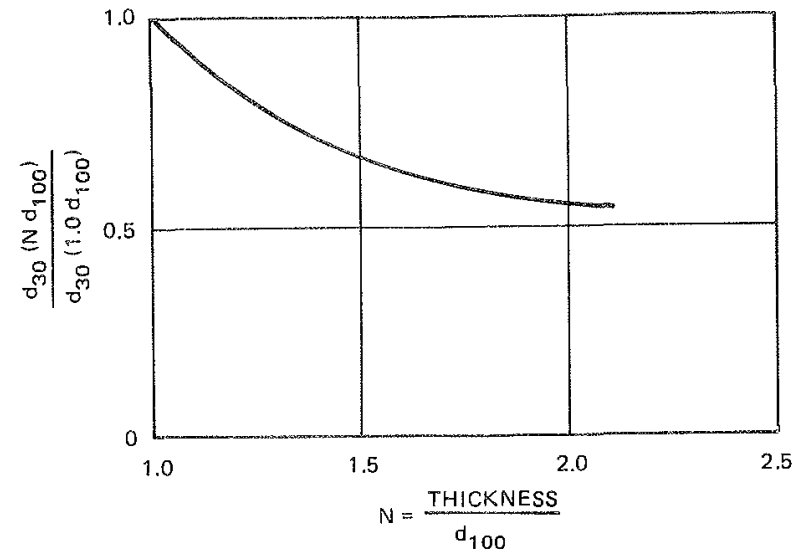

b. Thickness adjustment for $d_{85} / d_{15}=2.0002 .3$

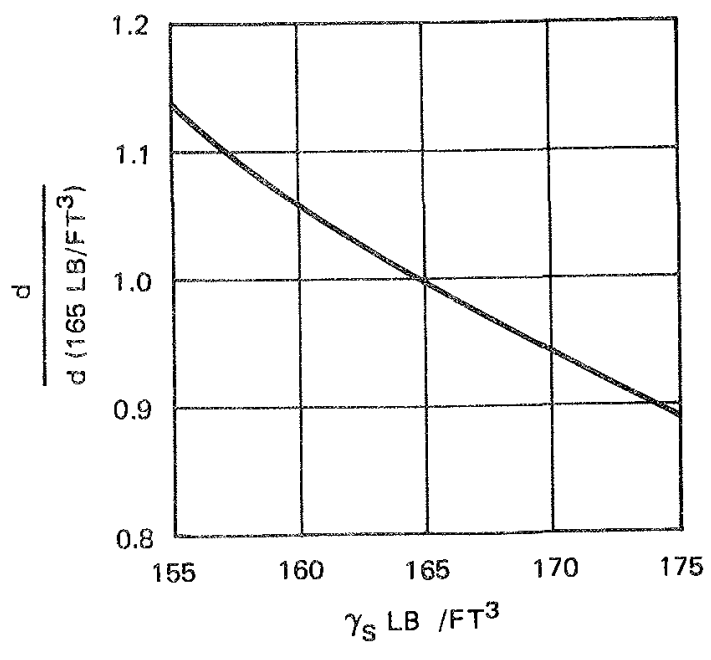

c. Correction for unit stone welght

Figure 5.1. Sizing nomograph for riprap

\subsection{SIZING NOMOGRAPH}

A sizing nomograph of Equation 5.1 is shown in Figure 5.1. In

Figure 5.Ia, the relationship of average veloctty in the vertical, depth, and $\mathrm{d}_{30}$ are given for a specific weight of 165 pcf and a blanket thickness of $1 \mathrm{~d}_{100}$. In Figure $5.1 \mathrm{~b}$, the adjustinent for thickness is given for gradations having $\mathrm{d}_{85} / \mathrm{d}_{15}=2.0-2.3$, which is similar to the gradations given in OCE (1971). In Figure 5.1c, the correction for unit weight of rock is given. 


\subsection{DESIGN APPLICATION}

This design procedure is based on the premise that a variety of tools are avallable for estimating the average velocity in the vertical for use in this design procedure. The average velocity in the vertical at the point of interest is used, not average cross-section values. The available tools for determining velocittes include the following:

1. Numerical Models: one-dimensional water-surface profile programs and multidtmensional models

2. Physical models

3. Prototype measurements

4. Analytical techniques such as the Californla Division of Highways (1970) equation

$$
v_{\max }=4 / 3 \text { (Average Channel Velocity) }
$$

which should be limited to prismatic channels, and the analysis of the data by Blodgett and McConaughy (1986) which gave the relation

$$
V_{\max }=1.53 \text { (Average Channel Velocity) }
$$

which would be applicable to natural channels.

Analytical techniques that need to be developed include

$$
\begin{aligned}
V_{\text {max }}= & f \text { (average channel velocity, bend radius/ } \\
& \text { water-surface width, channel shape (natural } \\
& \text { or prismatic), side slope angle, aspect ratio, } \\
& \text { bend angle, different bed and bank roughness) }
\end{aligned}
$$

\subsection{EXAMPLE DESIGN}

Determine size of side slope riprap for the design problem at Pinole Creek given in Blodgett and McConaughy (1.986) having the folm lowing conditions: 


$$
\begin{aligned}
& \text { Average channel velocity }=7.7 \mathrm{ft} / \mathrm{sec} \\
& \text { Average depth }=4.8 \mathrm{ft} \\
& \text { Maximum depth }=7.7 \mathrm{ft} \\
& \gamma_{\mathrm{s}}=175 \mathrm{pcf} \\
& \text { Curved channel (radius/width }=2.5 \text { ) } \\
& \text { Water-surface width }=61 \mathrm{ft} \\
& \text { Thickness }=1 \mathrm{~d}_{100} \\
& \text { Cotangent of side slope angle }=2
\end{aligned}
$$

As in most xiprap design problems, only the average channel velocity is known. The maximum average velocity in the vertical over the toe of the outer bank can be estimated by

$$
V_{\max }=1.53 V_{\text {avg }}=11.78 \mathrm{ft} / \mathrm{sec}
$$

This velocity and the maximum depth are used in equation 5.1. The size required for stability is $\mathrm{d}_{30}=0.64 \mathrm{ft}$. At Pinole Creek prototype, riprap having a $d_{30}$ of 0.45 ft and a undt stone weight of 178 pef failed under the given hydraulic conditions.

Using OCE (1971) gradations given in Table 4.21, a blanket thickness of 18 in. provides a $\mathrm{d}_{30}$ (minimum) of $0.73 \mathrm{ft}$ for a unit stone weight of 175 pcf. A blanket thickness of $15 \mathrm{in.} \mathrm{cannot} \mathrm{be} \mathrm{used} \mathrm{because}$ the $\mathrm{d}_{30}$ (minimum) of $0.61 \mathrm{ft}$ is less than $0.64 \mathrm{ft}$. For comparison, OCE (1970 and 1971) riprap sizing guidance using a constant Shields coefficient and the logarithmic velocity relations results in a $\mathrm{d}_{50}$ of $1.17 \mathrm{ft}$. The 24 in. blanket thickness given in Table 4.21 for a unit stone weight of 175 pef provides a $\mathrm{d}_{50}$ (mininum) of $1.17 \mathrm{fto}$ 


\subsection{SUMMARY OF LIMITATIONS}

This design procedure is limited to the following conditions:

1. Straight and curved open channels that are not immediately downstream of a structure that creates a hydraulic jump.

2. Channel bottoms and channel side slopes less than or equal to $I V: 2 \mathrm{H}$

3. Slopes less than 2 percent, no overtopping embankment flows.

4. Froude number less than 1.2.

5. Ratlo of flow depth to $\mathrm{d}_{30}$ riprap size from 4 to 50 .

6. For thickness equal $1 \mathrm{~d}_{100}, \mathrm{~d}_{85} / \mathrm{d}_{15}$, less than or equal to 4.6. For thickness greater than $1 \mathrm{~d}_{100}, \mathrm{~d}_{85} / \mathrm{d}_{15}$ from $2.0-2.3$.

7. Angular rock. 
CHAPTER VI

\section{CONCLUSTONS AND RECOMMENDATIONS}

This investigation has shown that a constant Shields coefficient and the logarithmic velocity laws are not applicable to such high relative roughness problems as riprap design.

The critical velocity relation developed in this study for the threshold of incipient fallure of riprap is

$$
\frac{d_{30}}{D}=c_{16}\left[\left(\frac{\gamma_{W}}{\gamma_{S}-\gamma_{W}}\right)^{1 / 2} \frac{V}{\sqrt{g D}}\right]^{2.5}
$$

This relation was developed for stratght channel bottoms, straight channel side slopes of $1 \mathrm{~V}: 2 \mathrm{H}$, and curved channel side slopes of $1 \mathrm{~V}: 2 \mathrm{H}$.

Average velocity in the vertical at the point of interest is used, not average cross-sectional values. A relation of this form was first prow posed by Neill (1967) and Bogardi (1968).

This critical velocity relation was compared to the two most common riprap sizing methods: (1) critical shear stress using a constant Shields coefficient and (2) Isbash type relations $\left(d_{50}=C_{9} v^{2}\right)$. This critical velocity relation has an exponent that falls halfway between these two methods.

Riprap gradation unformity was shown to affect riprap stability if $d_{50}$ is used in the analysis. Use of particle size $d_{30}$ in the stability relations eliminates the effects of gradation uniformity for riprap thickness of $1 d_{100}$ and is used as the characteristic size in thls investigation. 
Riprap thickness was shown to have a significant affect on riprap stability for riprap gradation having $\mathrm{d}_{85} / \mathrm{d}_{15}$ of $2.1-2.3$.

Within the range tested, riprap shape did not have a significant effect on riprap stability. Gradations having 18 percent elongated particles $(\ell / b>3)$ exhibited the same stability as gradations not having elongated particles.

Existing side slope relations used in the critical shear stress equation overestimate the decrease in stability that occurs when a particle is placed on a sloping bank. This was demonstrated in two ways:

1. Comparison with the Hudson (1958) wave equation that showed the effects of side slope angle are more significant in channel flow than in wave attack.

2. Stability tests on sloping sides conducted in this investigation. The existing side slope stability relations matched the observed data when a repose angle of $53 \mathrm{deg}$ was used in the analysis instead of the commonly used $40 \mathrm{deg}$. This led to a series of repose angle tests which suggested that repose angle varies with revetment height, riprap thickness, surface texture, and placement method. Revetment height is important because the higher the bank, the greater the amount of material being supported by the rock at the toe of the slope. Because of these difficulties, repose angle was not used in the critical velocity relation and was included in the empirical coefficients just as Hudson did in his wave equation. Comparison of velocity profiles over channel side slopes in straight and curved reaches shows that for the same average velocity 
over the toe of the side slope, the velocity and shear stress on the side slope are significantly higher on the outer bank of the curved channel. Side slope stability tests in straight channels cannot be used in channel bends. The representative velocity used herein for side slope riprap stability is the average velocity in the vertical over the toe of the side slope. Maximum velocities in the curved channel tests occurred over the toe of the side slope.

Using depth and velocity over the toe of the side slope, the threshold of incipient failure of $1 \mathrm{~V}: 2 \mathrm{H}$ side slope riprap in straight channels is described by

$$
\frac{d_{30}}{D}=0.24\left[\left(\frac{\gamma_{w}}{\gamma_{s}-\gamma_{w}}\right)^{1 / 2} \frac{v}{\sqrt{g D}}\right]^{2.5}
$$

based on model and prototype data for thickness $=1 \mathrm{~d}_{100^{\circ}}$

For 1V:2H side slope riprap in curved channels

$$
\frac{\mathrm{d}_{30}}{\mathrm{D}}=0.30\left[\left(\frac{\gamma_{w}}{\gamma_{\mathrm{s}}-\gamma_{w}}\right)^{1 / 2} \frac{\mathrm{V}}{\sqrt{\mathrm{gD}}}\right]^{2.5}
$$

based on model and prototype data for thickness of $1 \mathrm{~d}_{100}$. This relation was also found applicable to bottom riprap in straight channels.

Since these relations define the threshold of incipient failure, safety factors must be determined before they can be used. A common problem in the design of xiprap is the addition of safety factors at each step in the design procedure. A safety factor of 1.2 times the $\mathrm{d}_{30}$ riprap size given by the threshold of incipient failure curve is used in the sizing nomograph (Figure 5.1) developed in this investigation. The designer can easily use other safety factors and apply them to the incipient failure relations. 
During this study, the following areas were identifled as needing additional study relative to open channel riprap design:

1. Effects of blanket thickness for gradations other than those studied in this investigation.

2. Effects of riprap shape outside the range covered in this study, including the effects of surface texture such as stability of cobble particles.

3. Side slope stability tests of $1 \mathrm{~V}: 1.5 \mathrm{H}$ and $1 \mathrm{~V}: 3 \mathrm{H}$.

4. Determining repose angle of riprap revetment so that it can be included in the design procedure.

5. Effect of revetment side slope height on stability. Side slope riprap in shallow channels may be much more stable than in deep channels due to the amount of material being supported by the toe of the slope.

6. Analytical methods for determining velocity in straight and curved channels for use in riprap sizing.

7. Using the experience of others involved in riprap design to better define appropriate safety factors. 


\section{REFERENCES}

Anderson, A. G., Paintal, A. S., and Davenport, J. T. (1968). "Tentative design procedure for riprap lined channe1s." Project Report

No. 96, St. Anthony Falls Hydraulic Laboratory, University of Minnesota, Minneapolis, Minn.

Anderson, A. G., Paintal, A. S., and Davenport, J。 T. (1970)。 "Tentative design procedure for riprap-lined channels." National Cooperative Highway Research Program Report 108, University of Minnesota,

Minneapolis, Minn.

Ashida, K, and Bayazit, Mo (1973). "Inftiation of motion and roughness of flows in steep channels. " proceedings, 15th Congress of the International Assoclation on Hydraulic Research, 1, 475-484.

Barr, D. Io, and Herbertson, JoG. (1966). Discussion of "Sediment transportation mechanics: Initiation of motion," by Task Comittee on Preparation of Sedimentation Manual, Journal of the Hydraulics Division, American Society of Civil Engineers, 92(HY6), 248-25l。

Bathuxst, Jo C., Graf, W. H., and CaO, H. H. (1982). "Initiation of sediment transport in steep channels with coarse bed material." Prom ceedings of Euromech 156: Colloquium on Mechanics of Sediment Transport, Istanbul, $207-213$.

Bayazit, M。 (1976). "Free Surface Flow in a Channel of Large Relative Roughness." Journal of Hydraulic Research, International Association on Hydrau11c Research, 14(2), 115-126.

Bayazit, $M_{0}$ (1982). "Plow structure and sediment transport mechanics in steep channels" Procedings of Euromech 156: Colloquium on Mechanics of Sediment Transport, Istanbul, $197-206$.

Bettess, R. (1984). "Initiation of sediment transport in gravel streams." Proceedings of the Institution of Civil Engineers, Technical Note 407, Part 2, 77.

Blench, T. (1966). Discussion of "Sediment Eransportation mechanics: initiation of motion, "by Task Committee on Preparation of Sedinentation Manual. Journal of the Hydraulics Division. American Society of Civil Engineers, 92(HY5), $287-288$ 。 
B1odgett, J. C., and McConaughy, C. E. (1986). "Rock riprap design for protection of stream channels near highway structures; Vo1 2, Evaluation of riprap design procedures." Water-Resources Investigations Report 864128, US Geological Survey, Sacramento, Calif.

Bogardi, J. L. (1968). "Incipient sediment motion in terms of critical mean velocity." Acta Technica Academiae Scientarium Hungaricae,

Budapest, $62(1-2), 1-24$.

Bogardi, J. L. (1978). Sediment transport in alluvial streams.

Akademiai Kiado, Budapest.

California Division of Highways. (1970). "Bank and shore protection in California highway practice." State of California, Department of Public Works, Sacramento, Calif.

Carter, A. C., Carlson, E. J。, and Lane, E. W. (1953). "Critical tractive forces on channel side slopes in coarse, non-cohesive materia1." Hydraulic Laboratory Report No. HYD -366 , US Bureau of Reclamation, Denver, Colo.

Chen, C. K., and Roberson, J. A. (1974). "Turbulence in wakes of roughness elements." Journal of the Hydraulics Division, American Society of Civil Engineers, 100(HY1), 53-67.

Christensen, B. A. (1972). "Incipient motion on cohesionless channe1 banks." Sedimentation, H. W. Shen, ed., 4-1--4-22, Fort Collins, Colo.

Coleman, H. W., Hodge, B. K., and Taylor, R. P. (1984). "A reevaluation of Schlichting"s surface roughness experiment." Journal of Fluids Engineering. American Society of Mechanical Engineers, 106, $60-65$.

Coleman, N. L. (1981). "Velocity profiles with suspended sediment." Journal of Hydraulic Research, 19(3), 211-229.

Cooper, R. H。 (1970). "A study of bed-material transport based on the analysis of flume experiments," thesis presented to the University of Alberta, Edmonton, Alberta, Canada, in partial fulfillment of the requirements for the degree of Doctor of Philosophy.

Daido, A. (1983). "Incipient motion and bed load of sediment in steep channe1." International Association for Hydraulic Research, 20th Congress, Moscow, Seminar 2, 3, 293-296.

Dubuat, P. 1786. Principes d'Hydraulique. 2nd Edition, Paris.

Einstein, H.A. (1942). "Formulas for the txansportation of bed load," Transactions, American Society of Civil Engineers, 107, 561-597.

Einstein, $H_{0} A_{4}$, and El-Samni, E。 A. 1949. "Hydrodynamic forces on a rough wall." Reviews of Modern Physics, 21 (3), 520-524. 
Escoffier, F, F. (1968). "Third sumary of progress, riprap study." US Army Engineer Waterways Experiment Station, Vicksburg, Miss.

Fiuzat, A. A., Chen, Y. H., and Simons, D. B. (1982). "Stability cests of riprap in flood control channels." Prepared under Contract

No. CER81-82AAF-YHC-DB556 by Colorado State Undversity, Fort Coljins, Colo., for the US Ariny Engineer Waterways Experiment Station, Vicksburg, Miss。

Fiuzat, A. A, and Richardson, E. V。 (1983). "Supplemental stability tests of riprap in flood control channels." Prepared under Contract No. CER83-84AAF-EVR18 by Colorado State University, Fort Col1ins, Colo., for the US Army Engineer Waterways Experiment Station, Vicksburg, Miss.

Forchheimer, P. (1914), Hydraulik, Teubner, Leipzig/Berlin.

Gessler, $Y_{0}$ (1971). "Beginning and ceasing of sediment motion," River Mechanics, Fort Collins, Colo, $\mathrm{H}$. W. Shen, ede, 1, 7-1-m-7-22.

Grace, Jo Lo, Jre, CaIhoun, C, Co, J $x_{0}$, and Brown, D。N. (1973). "Drainage and erosion control facilities, field performance Investigation," Miscellaneous Papex No. H-w3-6, US Army Engineer Waterways Experiment Station, Vicksburg, Miss.

Graf, W。H. (1971). Hydraulics of Sediment Transport. McGraw Hil1, New York.

Hey, R。D. (1979). "Flow resistance in grave1-bed rivers," Journal of the Hydraultcs Division, American Society of Civil Engineers, 105(HY9), $365-379$ 。

Hudson, $R, Y$. (1958). "Design of quarry-stone cover layers for rubblemound breakwaters." Research Report 2-2, US Army Engineer Waterways Experiment Station, Vicksburg, Miss.

Hughes, W. C., Urbonas, B., and Stevens, M. A. (1983). "Guidelines for the design of riprap channel linings." D. B. Simons Symposium on Erosion and Sedimentation, R. M. Li and $\bar{P}, S_{0}$ Lagasse, Fort Collins, $0010.9 .106-4.127$.

Isbash, S.V. (1935). "Construction of dams by dumping stones in flowing water" "Translated by A. Dorfilkov, US Army Engineer District, Eastport, Me。

Kamphius, J.W. (1974). "Detemination of sand roughness for fixed beds." Joumal of Hydraulic Research, International. Association on Hydraulic Research, 12(2), 193-203.

Keulegan, G.H。 (1938), "Laws of turbulent flow in open channels." Journal of Research of the National Bureau of Standards, Research Paper RP115, 21,707-741。 
Knight, D。W., and McDonald, J.A. (1979). "Hydraulic resistance of artificial strip roughness." Journal of the Hydraulics Division, American Society of Civil Engineers, 105(HY6), 675-690.

Lane, E. W. (1953). "Progress report on results of studies on the design of stable channels." Hydraulic Laboratory Report No. HYD-352, US Bureau of Reclamation, Denver, Colo.

Li, R。 M. Simons, D. B., Blinco, R. H., and Samad, M. A. (1976). "Probabilistic approach to design of riprap for river bank protection." Symposium on Inland Waterways for Navigation, Flood Control, and Water Diversions, Colorado State University, Fort Collins, Colo., II, $1572-1591$.

Maynoxd, S. T. (1978)。 "Practical riprap design." Miscellaneous Paper H-78-7, US Army Engineer Waterways Experiment Station, Vicksburg, Miss.

- "Open channel riprap design: incipient failure and friction coefficients for channel bottom riprap" (in preparation). US Army Engineer Waterways Experiment Station, Vicksburg, Miss.

Meyer-Peter, E。, and Muller, R. (1948). "Formulas for bed-load transport." Intemational Association for Hydraulic Structures Research, Second Meeting, Srockholm, Appendix 2, 39-64.

Miller, R. Lo, and Byrne, R. J。 (1965). "The angle of repose of a single grain on a fixed rough bed." Prepared under Contract Nonr -2121 (26) by the University of Chicago, Chicago, I1l, for Office of Nava1 Research.

National Crushed Stone Association. (1978). "Quarrted stone for erom sion and sediment control." Washington, D. Ca

Neil1, C. R。 (1967). "Mean-velocity criterion for scour of coarse uniform bedmaterial." International Association on Hydraulic Research, 12th Congress, Paper C6, $3, \mathrm{C} 6.1-\mathrm{C} 6.9$.

Nei11, C. R。 (1968). Mote on Initial movement of coarse unfform bedmaterial." Journal of Hydraulic Research. International Association on Hydraulice Research, $6(2), 173 \times 176$ 。

Nei11, C. R。, and Hey, R. D。 (1982), "Gravel-wed xivers: engineering problems." Gravel-Bed Rivers, R. D. Hey, J.C. Bathurst, and C.R. Thorne, ed. Wiley and Sons, Chichester, N. Y.

Nei1I, C.R., and Van Der Giessen. (1966). Discussion of "Sediment transportation mechanics: initiation of motion," by Task Committee on Pxepaxation of Sedimentation Manual, Journal of the Hydraulics Division, American Society of Civil Engineers, 92(HY5), 280-287.

Office, Chief of Engineers, Us Army. (1970). "Hydraulic design of flood control channe1s." EM 1110-2-1601, US Government Printing Office, Washington, D。C. 
Office, Chief of Engineers, US Army. (1971). "Additional guidance for xiprap channel protection" ETL 1110-2 120, vS Governmenc Printing office, Washington, D, C.

Olivier, H. (1967). "Through and ovexflow rockfill dams - new design cechnlques." Proceedings of the Insticution of Civil Engineers, 36 $(7012), 433-471$.

O'Loughtin, $E_{8} M_{0}$ and McDonald, E。 Go (1964). "Sone roughness concentration effects on boundary resistance." La Houlle Blanche, 7 , $773-782$.

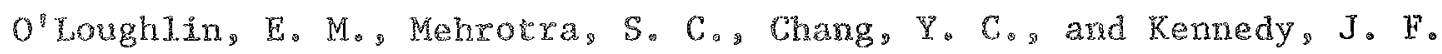
(1970). "Scale efrects in hydradic model tests or rock protected structures." ITHR Report No. 124, Iowa Institute of Hydraulic Research, Towa City, Ia.

Peterka, A. J. (1958). "Hydreulic design of stiling basins and energy dissfipators." Engineerfng Monograph No. 25, US Bureau of Reclamation, Denver, Colo.

Rese, A. (1984). "Riprap stzing wour methodso" Proceedings of the American Society of Civil Engineers 1 gydxaufics Specialty Conference, Coevr d'Alene. Ida. 397-401.

Ruff, J. F, Shaikh, A, Abt, S. R., and Richardson, E。 V。 (1985). "Riprap tests in flood control channes." Prepared under Contract No. CER85-86-JFR-AS-SRA-EVR-17 by Colorado State University, Fort Collins, Colo. for the US Army Engineer Waterways Experiment Station, Vicksburg, Miss.

Ruff, Jo Fo, Shatkh, Aos Abs, $S_{0} R_{0}$, and Richardson, E, Vo (1987). "Riprap stability in aide sloped channels." Prepared under Contract No. DACW39-83mC-C045, by Colorado State University, Fort Collins, Colo., for the US Army Engineer Watexways Experiment Gation, Vicksburg, Miss.

Schoklitsch, A. (1914). Uber Schleppleaft und Geschiebebewegung. Engelmann, LelpzJg. -1962. Handbuch des Wasserbaues. Springer-Verlag, VIenna.

Shen, H. H., and Lu, $J$. (1983). "Development and predicton of bed amoring." Journal of Hydraulic Englneering, Anerican Society of Civil Eugineers, $109(4) ; 611-629$.

Sheids, A. (1936). Applicacion of Simdlaxity Principles and TuxbuIence Research to Bed-Ioad Movement. English translation by W.P. ott and $J_{0}$ C. var Uchelon, California Institute of Technology, publiceston 167.

Simons, D. B., and Senturk, , (1977). Sediment Transport Technology. Water Resources Prblications. Fort Collins, Coto. 
Stevens, M。A., and Simons, D. B. (1971). "Stability analysis for coarse granuler material on slopes." River Mechanics, H. W. Shen, ed., Fort Collins, Colo., 1, 17-1--17-27.

Straub, L。 G. (1953)。 "Dredge fill closure of Missouri River at Fort Randa11." Proceedings of Minnesota International Hydraulics Convention, Minneapolis, Minn., 61-75.

Uram, E. M. (1981). "Analysis of the roughness function and wall law slope for rough surface turbulent boundary layers." Bioengineering, Fluids Engineerlng and Applied Mechanics Conference, American Society of Mechanical Engineers/American Sociefy of Civil Engineers, Boulder, Colo, $31=F E-36,1-=9$.

US Army Corps of Engineers. "Hydraulic design criteria." Prepared for Office, Chief of Engineers, by US Army Engineer Waterways Experiment Station, Vicksburg, Miss. issued serially since 1952.

US Army Engineer Discrict, Portland. (1952). "High velocity revetment tests. Civil Works Investigation -485 , Portland, Ore.

US Army Engineer Division, Lower Mississippi Valley, (1982). "Report on standardization of xiprap gradations" (Revised). Vicksburg, Miss.

US Department of Transportation. (1975). "Design of stable channels with flexible 1inings." Hydraulic Engineering Circular No. 15, Federal Highway Administration, Washington, D. C.

Vanoni, V.A. (1977). "Sedimentation engineering." American Society of Civil Engineers Manuals and Reports on Engineering Practice No. 54, New York.

van Rijn, L. C. (1982)。 "Equivalent roughness of alluvial bed." Journal of the Hydraulics Division. American Society of Civil Engineers. Technical Note, 108(HY10), 1215-1218.

Yalin. M. S. (1965). "Similarity in sediment transport by currents." Hydraulics Research Paper No.6, HM Stationery Office, London.

Yalin, $M$. $S_{0}$ (1977). Mechanics of sediment transpott. Pergamon Press, Elms Ford, N. Y. 
Table 3,1

Mode1 Riprap

\begin{tabular}{|c|c|c|c|c|c|c|c|}
\hline & Flume & $\begin{array}{l}\text { Test } \\
\text { Phase } \\
\end{array}$ & $\begin{array}{r}\mathrm{d}_{50} \\
\text { in. } \\
\end{array}$ & Thickness & $\frac{d_{85}}{d_{15}}$ & Gradation, in. & $\begin{array}{l}\gamma_{s} \\
p c f\end{array}$ \\
\hline $\cos \theta$ & & $I$ & 1.87 & $1.0 d_{100}$ & 2.8 & Figure $3.4^{a}$ & 170 \\
\hline $\cos \theta$ & & 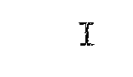 & 3.0 & $1.0 d_{100}$ & 3.9 & Figure $3.4^{a}$ & 1.70 \\
\hline $\operatorname{csu}$ & & II & 0.5 & $1.0 d_{100}$ & 4.6 & Figure $3.5^{\mathrm{b}}$ & 166 \\
\hline $\operatorname{csu}$ & & $I I$ & 1.0 & $1.0 d_{100}$ & 4.6 & Fgure $3.5^{b}$ & 166 \\
\hline $\operatorname{CsU}$ & & III & 1.0 & $\begin{array}{l}1.4 d_{100} \& \\
2.1 d_{100}\end{array}$ & 2.1 & Figure $3.6^{\mathrm{c}}$ & 167 \\
\hline $\operatorname{cst} \theta$ & & IIT & 2.0 & $\begin{array}{l}1.4 d_{100} \\
2.1 d_{100}\end{array}$ & 2.3 & Fingure $3.6^{c}$ & 165 \\
\hline $\operatorname{csU}$ & & IV & 0.5 & $1.0 d_{100}$ & 2.0 & Figure $3.7^{\mathrm{d}}$ & 167 \\
\hline $\operatorname{cs} U$ & & IV & 1.0 & $\begin{array}{l}1.0 d_{100} \& \\
1.3 d_{100}\end{array}$ & 2.3 & Figure $3.7^{\mathrm{d}}$ & 167 \\
\hline WES & Trapezoidal & $\mathrm{I}$ & 0.31 & $1.5 \mathrm{~d}_{100}$ & 2.0 & OCE $(1971)^{e}$ & 167 \\
\hline WES & Trapezoidal & I & 0.38 & $1_{.5} d_{100}$ & 2.0 & $\operatorname{OCE}(1971)^{e}$ & 167 \\
\hline WES & Trapezoidal & $I$ & 0.44 & $1.5 d_{100}$ & 2.0 & $\operatorname{OCE}(1971)^{e}$ & 167 \\
\hline WES & Tilting & $\mathrm{T}$ & 0.86 & $1.0 d_{100}$ & 1.23 & $3 / 4-1$ & 167 \\
\hline WES & Tilting & $I$ & 0.61 & $1.0 d_{100}$ & 1.33 & $1 / 2-3 / 4$ & 167 \\
\hline WES & Tilting & $I$ & 0.43 & $1.0 d_{100}$ & 1.24 & $3 / 8=1 / 2$ & 167 \\
\hline
\end{tabular}

(Continued)

\footnotetext{
See FIgure 3.4 for gradation. See Figure 3.5 for gradation. See figure 3.6 for gradation. See Figure 3.7 Eor gradacion. See OCE (1.971) for gradation.
} 
Table 3.1 (Concluded)

\begin{tabular}{|c|c|c|c|c|c|c|c|}
\hline & Flume & $\begin{array}{l}\text { Test } \\
\text { Phase } \\
\end{array}$ & $\begin{array}{l}\mathrm{d}_{50} \\
\text { in. } \\
\end{array}$ & Thickness & $\frac{\mathrm{d}_{85}}{\mathrm{~d}_{15}}$ & Gradation, in. & $\begin{array}{l}Y_{s} \\
\text { pcf }\end{array}$ \\
\hline WES & Tilting & I & 0.30 & $1.0 \mathrm{~d}_{100}$ & 1.56 & 非 $4-3 / 8$ & 167 \\
\hline WES & Tilting & II & 0.43 & $1.0 d_{100}$ & 2.5 & $\begin{array}{ll}33 \% & 1 / 2-3 / 4 \\
33 \% & 3 / 8-1 / 2\end{array}$ & 167 \\
\hline WES & Tilting & III & 0.43 & $1.0 \mathrm{~d}_{100}$ & 2.5 & $33 \%$ \# $4-3 / 8$ & 167 \\
\hline WES & rilting & III & 0.61 & $1.0 \mathrm{~d}_{100}$ & 2.1 & $\begin{array}{ll}33 \% & 3 / 4-1 \\
33 \% & 1 / 2-3 / 4 \\
33 \% & 3 / 8-1 / 2\end{array}$ & 167 \\
\hline WES & Tilting & IV & 0.30 & Varied & 1.56 & $\# 4-3 / 8$ & 167 \\
\hline WES & Curved & $I$ & 0.38 & $1.0 \mathrm{~d}_{100}$ & 2.0 & $\begin{array}{ll}50 \% & \# 4-3 / 8 \\
50 \% & 3 / 8-1 / 2\end{array}$ & 167 \\
\hline
\end{tabular}


Table 3.2

Shape Characteristics of Mode 1 Riprap

\begin{tabular}{lcccc}
\hline Test Rock & Rock Size, in & $\begin{array}{c}\text { Percent } \\
\text { Greater than } \\
\ell / \mathrm{b}=2.5\end{array}$ & $\begin{array}{c}\text { Percent } \\
\text { Greater than } \\
\ell / \mathrm{b}=3\end{array}$ \\
\hline WES & $\begin{array}{l}\# 4-1 \\
\text { CSU (1st test series) }\end{array}$ & $2-6$ & 29 & 17 \\
CSU (2nd test series) & $3 / 8-1-1 / 2$ & 16 & 7 \\
CSU (3rd test series) & $\$ 4-1-1 / 2$ & 37 & 18 \\
CSU (4th test series) & $\# 4-1-1 / 2$ & 30 & 18
\end{tabular}

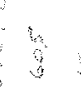

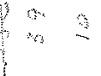

2
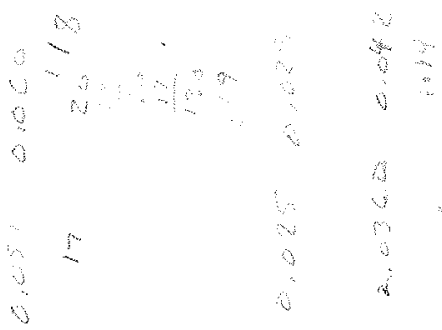
Table 4.1

WES Tilting Flume, Phase I Test Results for $\mathrm{d}_{85} / \mathrm{d}_{15}=1.35$, Thickness $=$ $1.18 \mathrm{~d}_{50}=1 \mathrm{~d}_{100 \gamma_{\mathrm{s}}=167 \mathrm{psf} \text {, Shape Characteristics Not Meeting }}$

Corps Guidance

\begin{tabular}{|c|c|c|c|c|c|c|c|}
\hline $\begin{array}{l}\text { Energy } \\
\text { Slope } \\
\text { ft/ft }\end{array}$ & $\begin{array}{l}\text { Average } \\
\text { Velocity } \\
\mathrm{ft} / \mathrm{sec}^{\mathrm{a}} \\
\end{array}$ & $\begin{array}{c}\text { Average } \\
\text { Depth } \\
\mathrm{ft} \\
\end{array}$ & $\mathrm{d}_{30} / \mathrm{ft}$ & $\mathrm{d}_{50} / \mathrm{ft}$ & $\mathrm{d}_{90} / \mathrm{ft}$ & $\begin{array}{l}\text { Sieve } \\
\text { Size, in. }\end{array}$ & $\begin{array}{r}\text { Stable or } \\
\text { Failed or } \\
\text { Unknown } \\
\end{array}$ \\
\hline 0.01800 & 4.34 & 0.400 & 0.068 & 0.072 & 0.081 & $3 / 4-1$ & $S$ \\
\hline 0.02000 & 4.45 & 0.405 & 0.068 & 0.072 & 0.081 & $3 / 4-1$ & $\mathrm{~F}$ \\
\hline 0.01600 & 3.20 & 0.301 & 0.047 & 0.051 & 0.060 & $1 / 2-3 / 4$ & $S$ \\
\hline 0.01700 & 3.23 & 0.290 & 0.047 & 0.051 & 0.060 & $1 / 2-3 / 4$ & $\mathrm{~F}$ \\
\hline 0.02100 & 3.23 & 0.227 & 0.047 & 0.051 & 0.060 & $1 / 2-3 / 4$ & $\mathrm{~F}$ \\
\hline 0.02100 & 2.90 & 0.228 & 0.047 & 0.051 & 0.060 & $1 / 2-3 / 4$ & $\mathrm{~S}$ \\
\hline 0.00900 & 3.60 & 0.501 & 0.047 & 0.051 & 0.060 & $1 / 2-3 / 4$ & S \\
\hline 0.01000 & 3.80 & 0.470 & 0.047 & 0.051 & 0.060 & $1 / 2-3 / 4$ & F \\
\hline 0.01100 & 3.49 & 0.402 & 0.047 & 0.051 & 0.060 & $1 / 2-3 / 4$ & S \\
\hline 0.01200 & 3.58 & 0.391 & 0.047 & 0.051 & 0.060 & $1 / 2-3 / 4$ & $\mathrm{~F}$ \\
\hline 0.01500 & 3.47 & 0.327 & 0.047 & 0.051 & 0.060 & $1 / 2-3 / 4$ & S \\
\hline 0.01600 & 3.56 & 0.319 & 0.047 & 0.051 & 0.060 & $1 / 2-3 / 4$ & $\mathrm{~F}$ \\
\hline 0.02100 & 3.11 & 0.258 & 0.047 & 0.051 & 0.060 & $1 / 2-3 / 4$ & S \\
\hline 0.02100 & 3.17 & 0.263 & 0.047 & 0.051 & 0.060 & $1 / 2-3 / 4$ & $\mathrm{~F}$ \\
\hline 0.00500 & 3.34 & 0.530 & 0.019 & 0.025 & 0.029 & $3 / 8$ 我非 4 & $F$ \\
\hline 0.00530 & 3.37 & 0.534 & 0.019 & 0.025 & 0.029 & $3 / 8-1 / 4$ & $\mathrm{~F}$ \\
\hline 0.00680 & 3.38 & 0.400 & 0.019 & 0.025 & 0.029 & $3 / 8-\| \equiv 4$ & $?^{\mathrm{C}}$ \\
\hline 0.00800 & 3.52 & 0.389 & 0.019 & 0.025 & 0.029 & $3 / 8-\# 4$ & $\mathrm{~F}$ \\
\hline 0.02100 & 3.06 & 0.131 & 0.019 & 0.025 & 0.029 & $3 / 8-\|=4$ & $?$ \\
\hline 0.02200 & 3.11 & 0.129 & 0.019 & 0.025 & 0.029 & $3 / 8-\# 4$ & $\mathrm{~F}$ \\
\hline 0.00900 & 2.44 & 0.205 & 0.019 & 0.025 & 0.029 & $3 / 8-1 \mid 4$ & $?$ \\
\hline 0.01000 & 2.53 & 0.198 & 0.019 & 0.025 & 0.029 & $3 / 8-\# 4$ & $F$ \\
\hline 0.01200 & 3.17 & 0.210 & 0.019 & 0.025 & 0.029 & $3 / 8-n=4$ & $?$ \\
\hline 0.01300 & 3.26 & 0.204 & 0.019 & 0.025 & 0.029 & $3 / 8-$ 非 4 & $\mathrm{~F}$ \\
\hline 0.00570 & 2.59 & 0.325 & 0.019 & 0,025 & 0.029 & $3 / 8-\|$ 非 & $?$ \\
\hline 0.00700 & 2.75 & 0.303 & 0.019 & 0.025 & 0.029 & $3 / 8-1 \mid 4$ & $F$ \\
\hline 0.00940 & 3.75 & 0.310 & 0.019 & 0.025 & 0.029 & $3 / 8-\# 4$ & $?$ \\
\hline 0.01000 & 2.71 & 0.220 & 0.019 & 0.025 & 0.029 & $3 / 8-\# 4$ & $\mathrm{~F}$ \\
\hline 0.00500 & 2.82 & 0.402 & 0.019 & 0.025 & 0.029 & $3 / 8-\| \equiv$ & $?$ \\
\hline 0.00600 & 3.03 & 0.377 & 0.019 & 0.025 & 0.029 & $3 / 8-34$ & $\mathrm{~F}$ \\
\hline 0.00400 & 2.88 & 0.487 & 0.019 & 0.025 & 0.029 & $3 / 8-1 / 4$ & $?$ \\
\hline 0.00500 & 3.00 & 0.461 & 0.019 & 0.025 & 0.029 & $3 / 8-\| 14$ & F \\
\hline
\end{tabular}

(Continued)

\footnotetext{
a Velocity based on discharge/area.

$\mathrm{b} S=$ stable; $\mathrm{F}=$ failed; ? = unknown.

c Stable but tested for a short duration compared to the other tests.

d Width/depth $<5$.
} 
Table 4.1 (Concluded)

\begin{tabular}{|c|c|c|c|c|c|c|c|}
\hline $\begin{array}{l}\text { Energy } \\
\text { Slope } \\
\mathrm{ft} / \mathrm{ft}\end{array}$ & $\begin{array}{l}\text { Average } \\
\text { Velocity } \\
\mathrm{ft} / \mathrm{sec}^{\mathrm{a}} \\
\end{array}$ & $\begin{array}{c}\text { Average } \\
\text { Depth } \\
\mathrm{ft} \\
\end{array}$ & $\mathrm{d}_{30} / \mathrm{ft}$ & $\mathrm{d}_{50} / \mathrm{ft}$ & $\mathrm{d}_{90} / \mathrm{ft}$ & $\begin{array}{l}\text { Sieve } \\
\text { Size, in. }\end{array}$ & $\begin{array}{c}\text { Stable or } \\
\text { Failed or } \\
\text { Unknown } \\
\end{array}$ \\
\hline 0.00300 & 2.73 & $0.633^{d}$ & 0.019 & 0.025 & 0.029 & $3 / 8-$ 非 4 & ? \\
\hline 0.00400 & 2.95 & 0.589 & 0.019 & 0.025 & 0.029 & $3 / 8-1 \mid 4$ & $F$ \\
\hline 0.00500 & 3.28 & 0.564 & 0.034 & 0.036 & 0.041 & $1 / 2-3 / 8$ & $\mathbf{F}$ \\
\hline 0.00390 & 2.93 & 0.591 & 0.034 & 0.036 & 0.041 & $1 / 2-3 / 8$ & S \\
\hline 0.00800 & 3.06 & 0.368 & 0.034 & 0.036 & 0.041 & $1 / 2-3 / 8$ & $\mathrm{~F}$ \\
\hline 0.00900 & 3.23 & 0.353 & 0.034 & 0.036 & 0.041 & $1 / 2-3 / 8$ & $\mathrm{~S}$ \\
\hline 0.00700 & 2.93 & 0.386 & 0.034 & 0.036 & 0.041 & $1 / 2-3 / 8$ & $\mathrm{~s}$ \\
\hline 0.01810 & 2.77 & 0.181 & 0.034 & 0.036 & 0.041 & $1 / 2-3 / 8$ & $\mathrm{~S}$ \\
\hline 0.01950 & 2.82 & 0.178 & 0.034 & 0.036 & 0.041 & $1 / 2-3 / 8$ & F \\
\hline 0.00930 & 2.91 & 0.297 & 0.034 & 0.036 & 0.041 & $1 / 2-3 / 8$ & $?$ \\
\hline 0.01 .000 & 2.95 & 0.293 & 0.034 & 0.036 & 0.041 & $1 / 2-3 / 8$ & $\mathrm{~F}$ \\
\hline 0.00900 & 2.82 & 0.306 & 0.034 & 0.036 & 0.041 & $1 / 2-3 / 8$ & $\mathrm{~S}$ \\
\hline 0.00520 & 3.03 & 0.494 & 0.034 & 0.036 & 0.041 & $1 / 2-3 / 8$ & $?$ \\
\hline 0.00600 & 3.28 & 0.463 & 0.034 & 0.036 & 0.041 & $1 / 2-3 / 8$ & $F$ \\
\hline
\end{tabular}

a Velocity based on discharge/area.

b $S=$ stable; $F=$ falled $;=$ unknown. 
Table 4.2

CSU Phase I,

Test Results for $\mathrm{d}_{85} / \mathrm{d}_{15}=2.8$, Thickness $=2 \mathrm{~d}_{50}=1 \mathrm{~d}_{100}$,

$\mathrm{d}_{50}=1.87 \mathrm{in}, \mathrm{r}_{\mathrm{s}}=170$ pcf, Angular Particles, Does Not

\begin{tabular}{l} 
Meet Corps Shape Guidance $\quad D_{83}=0.42$ \\
\hline
\end{tabular}

\begin{tabular}{|c|c|c|c|c|c|}
\hline $\begin{array}{l}\text { Run } \\
\text { No. }\end{array}$ & $\begin{array}{c}\text { Orifice } \\
\text { Discharge } \\
\text { cfs } \\
\end{array}$ & $\begin{array}{l}\text { Flume } \\
\text { Slope } \\
\end{array}$ & $\begin{array}{l}\text { Average } \\
\text { Velocity } \\
\text { fps } \\
\end{array}$ & $\begin{array}{l}\text { Average } \\
\text { Depth } \\
\text { ft } \\
\end{array}$ & $\begin{array}{l}\text { Stable (S) or } \\
\text { Failed (F) }\end{array}$ \\
\hline 1 & 25 & 0.00852 & 3.62 & 0.825 & $S$ \\
\hline 2 & & 0.01378 & 4.34 & 0.687 & $\mathrm{~S}$ \\
\hline 3 & & 0.01667 & 4.62 & 0.653 & $\mathrm{~F}$ \\
\hline 4 & & 0.01973 & 5.11 & 0.629 & S \\
\hline 5 & 50 & 0.00761 & 4.78 & 1.218 & $\mathrm{~S}$ \\
\hline 6 & & 0.01089 & 5.24 & 1.110 & $\mathrm{~S}$ \\
\hline 7 & & 0.01451 & 5.92 & 1.032 & $\mathrm{~F}$ \\
\hline 8 & & 0.01266 & 6.01 & 1.051 & $\mathrm{~F}$ \\
\hline 9 & & 0.01089 & 5.35 & 1.151 & $\mathrm{~F}$ \\
\hline 10 & 75 & 0.00537 & 5.39 & $1.868^{\mathrm{a}}$ & S \\
\hline 11 & & 0.00769 & 5.38 & $1.716^{\mathrm{a}}$ & $\mathrm{S}$ \\
\hline 12 & & 0.01025 & 5.92 & 1.509 & $\mathrm{~F}$ \\
\hline 13 & & 0.00894 & 5.64 & $1.604^{\mathrm{a}}$ & $\mathrm{F}$ \\
\hline 14 & & 0.00769 & 5.39 & $1.700^{\mathrm{a}}$ & $S$ \\
\hline 15 & 100 & 0.00420 & 5.39 & $2.325^{a}$ & S \\
\hline 16 & & 0.00601 & 5.32 & $2.111^{\mathrm{a}}$ & $s$ \\
\hline 17 & & 0.00801 & 6.03 & $2.010^{2}$ & $\mathrm{~F}$ \\
\hline 18 & & 0.00699 & 5.86 & $2.012^{\mathrm{a}}$ & F \\
\hline 19 & & 0.00601 & 5.68 & $2.062^{\mathrm{a}}$ & $\mathrm{S}$ \\
\hline
\end{tabular}

aidth/depth $<5$. 
Table 4.3

CSU Phase II,

Test Results for $\mathrm{d}_{85} / \mathrm{d}_{15}=2.5$, Thickness $=2 \mathrm{~d}_{50}=1 \mathrm{~d}_{100}$,

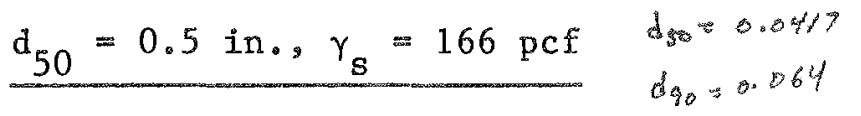

\begin{tabular}{cccccc}
\hline $\begin{array}{c}\text { Run } \\
\text { No. }\end{array}$ & $\begin{array}{c}\text { Nominal } \\
\text { Discharge } \\
\text { cfs }\end{array}$ & $\begin{array}{c}\text { Flume } \\
\text { Slope }\end{array}$ & $\begin{array}{c}\text { Average } \\
\text { Velocity } \\
\text { fps }\end{array}$ & $\begin{array}{c}\text { Average } \\
\text { Depth } \\
\text { ft }\end{array}$ & $\begin{array}{c}\text { Stable (S) or } \\
\text { Failed (F) }\end{array}$ \\
\cline { 2 - 2 } 1 & 25 & 0.00143 & 1.763 & 1.434 & $\mathrm{~S}$ \\
2 & 25 & 0.00185 & 2.269 & 1.335 & $\mathrm{~S}$ \\
3 & 25 & 0.00231 & 2.391 & 1.277 & $\mathrm{~S}$ \\
4 & 25 & 0.00280 & 2.779 & 1.106 & $\mathrm{~S}$ \\
5 & 25 & 0.00331 & 2.940 & 1.021 & $\mathrm{~F}$ \\
6 & 25 & 0.00331 & 3.147 & 0.922 & $\mathrm{~F}$ \\
7 & 25 & 0.00280 & 3.212 & 1.201 & $\mathrm{~F}$ \\
8 & 25 & 0.00231 & 3.155 & 1.030 & $\mathrm{~F}$ \\
& & & & & $\mathrm{~F}$ \\
9 & 50 & 0.00102 & 3.022 & $1.961^{\mathrm{a}}$ & $\mathrm{F}$ \\
10 & 50 & 0.00128 & 3.135 & $1.894^{\mathrm{a}}$ & $\mathrm{F}$ \\
12 & 50 & 0.00102 & 3.085 & $2.047^{\mathrm{a}}$ & $\mathrm{F}$ \\
13 & & & & & $\mathrm{~F}$ \\
14 & 75 & 0.00072 & 3.410 & $2.958^{\mathrm{a}}$ & $\mathrm{F}$ \\
15 & 75 & 0.00090 & 3.610 & $2.724^{\mathrm{a}}$ & $\mathrm{S}$ \\
16 & 75 & 0.00072 & 3.372 & $2.855^{\mathrm{a}}$ & $\mathrm{S}$ \\
17 & 75 & 0.00056 & 3.154 & $3.026^{\mathrm{a}}$ &
\end{tabular}


Table 4.4

CSU Phase III,

$\frac{\text { Test Results for } \mathrm{d}_{85} / \mathrm{d}_{15}=2.1 \text {, Thickness }=2 \mathrm{~d}_{50}=1.4 \mathrm{~d}_{100}}{\frac{\mathrm{d}_{50}=1 \mathrm{in.}, \gamma_{\mathrm{S}}=167 \mathrm{pcf}, \text { Shape Characteristics }}{\text { Meeting Corps Guidance }}}$

\begin{tabular}{lccccc}
\hline $\begin{array}{l}\text { Run } \\
\text { No. }\end{array}$ & $\begin{array}{c}\text { Nominal } \\
\text { Discharge } \\
\text { cfs }\end{array}$ & $\begin{array}{c}\text { Flume } \\
\text { Slope }\end{array}$ & $\begin{array}{c}\text { Average } \\
\text { Velocity } \\
\text { fps }\end{array}$ & $\begin{array}{c}\text { Average } \\
\text { Depth } \\
\text { ft }\end{array}$ & $\begin{array}{c}\text { Stable (S) or } \\
\text { Failed (F) }\end{array}$ \\
\cline { 2 - 2 } 33 & 25 & 0.00998 & 4.40 & 0.684 & $\mathrm{~S}$ \\
34 & 25 & 0.01088 & 4.51 & 0.703 & $\mathrm{~S}$ \\
35 & 25 & 0.01186 & 4.72 & 0.672 & $\mathrm{~S}$ \\
36 & 25 & 0.01337 & 4.95 & 0.618 & $\mathrm{~F}$ \\
37 & 25 & 0.01204 & 4.77 & 0.651 & $\mathrm{~F}$ \\
32 & 50 & 0.00558 & 4.90 & & $\mathrm{~F}$ \\
41 & 50 & 0.00475 & 4.71 & 1.300 & $\mathrm{~F}$ \\
38 & 75 & 0.00402 & 5.02 & $1.832^{\mathrm{a}}$ & $\mathrm{F}$ \\
39 & 75 & 0.00377 & 5.00 & $1.842^{\mathrm{a}}$ & $\mathrm{F}$ \\
40 & 75 & 0.00345 & 4.84 & $1.918^{\mathrm{a}}$ & $\mathrm{S}$ \\
& & & & & $\mathrm{S}$ \\
42 & 100 & 0.00314 & 4.97 & $2.371^{\mathrm{a}}$ & $\mathrm{S}$ \\
43 & 100 & 0.00403 & 4.90 & $2.415^{\mathrm{a}}$ & $\mathrm{F}$ \\
44 & 100 & 0.00436 & 5.20 & $2.210^{\mathrm{a}}$ & $\mathrm{F}$ \\
45 & 100 & 0.00354 & 5.09 & $2.332^{\mathrm{a}}$ &
\end{tabular}

a Width/depth $<5$. 
Table 4.5

CSU Phase III,

Test Results for $\mathrm{d}_{85} / \mathrm{d}_{15}=2.3$, Thickness $=2 \mathrm{~d}_{50}=1.4 \mathrm{~d}_{100}$,

$\mathrm{d}_{50}=2$ in., $\gamma_{\mathrm{s}}=165$ pcf, Shape Characteristics

Meeting Corps Guidance

\begin{tabular}{lccccc}
\hline $\begin{array}{l}\text { Run } \\
\text { No. }\end{array}$ & $\begin{array}{c}\text { Nomina1 } \\
\text { Discharge } \\
\text { cfs }\end{array}$ & $\begin{array}{c}\text { Flume } \\
\text { Slope }\end{array}$ & $\begin{array}{c}\text { Average } \\
\text { Velocity } \\
\text { fps }\end{array}$ & $\begin{array}{c}\text { Average } \\
\text { Depth } \\
\text { ft }\end{array}$ & $\begin{array}{c}\text { Stable (S) or } \\
\text { Failed (F) }\end{array}$ \\
76 & 25 & 0.01193 & 4.55 & 0.681 & $\mathrm{~S}$ \\
77 & 25 & 0.01858 & 5.27 & 0.598 & $\mathrm{~S}$ \\
65 & 50 & 0.00998 & 5.03 & 1.246 & $\mathrm{~S}$ \\
66 & 50 & 0.01378 & 6.13 & 1.019 & $\mathrm{~S}$ \\
67 & 50 & 0.01519 & 6.36 & 0.987 & $\mathrm{~S}$ \\
68 & 50 & 0.01796 & 6.71 & 0.935 & $\mathrm{~S}$ \\
69 & 50 & 0.01888 & 6.63 & 0.948 & $\mathrm{~F}$ \\
78 & 50 & 0.01579 & 6.14 & 1.022 & $\mathrm{~F}$ \\
70 & 75 & 0.01110 & 6.65 & 1.410 & $\mathrm{~F}$ \\
71 & 75 & 0.00781 & 6.33 & 1.483 & $\mathrm{~S}$ \\
72 & 75 & 0.00937 & 6.81 & 1.423 & $\mathrm{~S}$ \\
73 & & & & & $\mathrm{~S}$ \\
74 & 100 & 0.00731 & 6.43 & $1.954^{\mathrm{a}}$ & $\mathrm{F}$
\end{tabular}

a Width/depth $<5$. 
Table 4.6

CSU Phase III,

$\frac{\text { Test Results for } d_{85} / d_{15}=2.1 \text {, Thickness }=3 d_{50}=2.1 d_{100}}{\frac{d_{50}=1 \text { in. } \gamma_{s}=167 \text { pcf, Shape Characteristics }}{\underline{\text { Meeting Corps Guidance }}}}$

\begin{tabular}{|c|c|c|c|c|c|}
\hline $\begin{array}{l}\text { Run } \\
\text { No. }\end{array}$ & $\begin{array}{c}\text { Nominal } \\
\text { Discharge } \\
\text { cfs } \\
\end{array}$ & $\begin{array}{l}\text { Flume } \\
\text { Slope }\end{array}$ & $\begin{array}{l}\text { Average } \\
\text { Velocity } \\
\text { fps } \\
\end{array}$ & $\begin{array}{l}\text { Average } \\
\text { Depth } \\
\text { ft } \\
\end{array}$ & $\begin{array}{l}\text { Stable (S) or } \\
\text { Failed (F) }\end{array}$ \\
\hline 46 & 25 & 0.00880 & 4.37 & 0.720 & $S$ \\
\hline 47 & 25 & 0.01011 & 4.61 & 0.688 & S \\
\hline 48 & 25 & 0.01313 & 5.02 & 0.640 & S \\
\hline 57 & 25 & 0.01475 & 5.02 & 0.625 & $S$ \\
\hline 58 & 25 & 0.01626 & 5.52 & 0.568 & $\mathrm{~F}$ \\
\hline 49 & 50 & 0.00526 & 4.94 & 1.268 & $\mathrm{~S}$ \\
\hline 50 & 50 & 0.00636 & 5.36 & 1.169 & $\mathrm{~S}$ \\
\hline 52 & 50 & 0.00726 & 5.74 & 1.096 & $\mathrm{~S}$ \\
\hline 53 & 50 & 0.00802 & 5.66 & 1.095 & $\mathrm{~F}$ \\
\hline 54 & 50 & 0.00732 & 5.64 & 1.111 & $\mathrm{~F}$ \\
\hline 55 & 50 & 0.00732 & 5.03 & 1.245 & $\mathrm{~F}$ \\
\hline 56 & 50 & 0.00647 & 5.11 & 1.231 & $S$ \\
\hline 59 & 75 & 0.00423 & 4.90 & $1.907^{\mathrm{a}}$ & $\mathrm{s}$ \\
\hline 60 & 75 & 0.00517 & 5.11 & $1.814^{a}$ & $S$ \\
\hline 61 & 75 & 0.0062 .1 & 5.50 & $1.714^{a}$ & F \\
\hline 62 & 100 & 0.00406 & 4.63 & $2.513^{2}$ & $\mathrm{~S}$ \\
\hline 63 & 100 & 0.00457 & 5.25 & $2.210^{a}$ & $\mathrm{~F}$ \\
\hline 64 & 100 & 0.00409 & 5.10 & $2.298^{\mathrm{a}}$ & S \\
\hline
\end{tabular}


Table 4.7

CSU Phase III,

Test Results for $\mathrm{d}_{85} / \mathrm{d}_{15}=2.3$, Thickness $=3 \mathrm{~d}_{50}=2.1 \mathrm{~d}_{100}$,

$d_{50}=2$ in., $\gamma_{s}=165$ pcf, Shape Characteristics

Meeting Corps Guidance

0,232

\begin{tabular}{|c|c|c|c|c|c|}
\hline $\begin{array}{l}\text { Run } \\
\text { No. }\end{array}$ & $\begin{array}{c}\text { Nominal } \\
\text { Discharge } \\
\text { cfs } \\
\end{array}$ & $\begin{array}{l}\text { Flume } \\
\text { S1ope } \\
\end{array}$ & $\begin{array}{l}\text { Average } \\
\text { Velocity } \\
\text { fps } \\
\end{array}$ & $\begin{array}{l}\text { Average } \\
\text { Depth } \\
\mathrm{ft}\end{array}$ & $\begin{array}{l}\text { Stable (S) or } \\
\text { Failed (F) }\end{array}$ \\
\hline 79 & 25 & 0.01180 & 4.42 & 0.710 & S \\
\hline 80 & 25 & 0.01870 & 5.17 & 0.607 & $\mathrm{~S}$ \\
\hline 81 & 50 & 0.01205 & 5.90 & 1.068 & $S$ \\
\hline 82 & 50 & 0.01544 & 6.47 & 0.966 & $\mathrm{~S}$ \\
\hline 83 & 50 & 0.01724 & 6.76 & 0.928 & $S$ \\
\hline 84 & 50 & 0.01879 & 6.61 & 0.970 & S \\
\hline 85 & 75 & 0.00898 & 6.19 & 1.519 & $\mathrm{~S}$ \\
\hline 86 & 75 & 0.01 .095 & 6.58 & 1.414 & $\mathrm{~S}$ \\
\hline 87 & 75 & 0.01206 & 6.63 & 1.423 & $\mathrm{~S}$ \\
\hline 88 & 75 & 0.01359 & 6.88 & 1.372 & S \\
\hline 89 & 75 & 0.01565 & 6.84 & 1.399 & F \\
\hline 90 & 100 & 0.00866 & 6.97 & $1.808^{a}$ & $\mathrm{~S}$ \\
\hline 91 & 100 & 0.00938 & 6.96 & $1.796^{\mathrm{a}}$ & S \\
\hline 92 & 100 & 0.01084 & 7.39 & $1.711^{\mathrm{a}}$ & $\mathrm{s}$ \\
\hline 93 & 100 & 0.01189 & 7.44 & $1.698^{\mathrm{a}}$ & S \\
\hline 94 & 100 & 0.01300 & 8.02 & 1.572 & $F$ \\
\hline
\end{tabular}

a Width/depth $<5$. 
Table 4.8

CSU Phase I,

Test Results for $\mathrm{d}_{85} / \mathrm{d}_{15}=3.9$, Thickness $=2 \mathrm{~d}_{50}=1 \mathrm{~d}_{100}$,

$\mathrm{d}_{50}=3$ in., $\gamma_{\mathrm{s}}=170$ pcf, Angular Particles, Does Not

Meet Corps Shape Guldance

\begin{tabular}{|c|c|c|c|c|c|}
\hline $\begin{array}{l}\text { Run } \\
\text { No. }\end{array}$ & $\begin{array}{c}\text { Orifice } \\
\text { Discharge } \\
\text { cfs } \\
\end{array}$ & $\begin{array}{l}\text { Flume } \\
\text { Slope }\end{array}$ & $\begin{array}{l}\text { Average } \\
\text { Velocity } \\
\text { fps } \\
\end{array}$ & $\begin{array}{c}\text { Average } \\
\text { Depth } \\
\text { ft } \\
\end{array}$ & $\begin{array}{l}\text { Stable (S) or } \\
\text { Failed (F) }\end{array}$ \\
\hline $\begin{array}{l}1 \\
2 \\
3\end{array}$ & $\begin{array}{l}25 \\
50\end{array}$ & $\begin{array}{l}0.02000 \\
0.01544 \\
0.02000\end{array}$ & $\begin{array}{l}4.51 \\
5.55 \\
6.09\end{array}$ & $\begin{array}{l}0.655 \\
1.064 \\
1.026\end{array}$ & $\begin{array}{l}S \\
S \\
S\end{array}$ \\
\hline $\begin{array}{l}4 \\
5 \\
6 \\
7\end{array}$ & 75 & $\begin{array}{l}0.01500 \\
0.01719 \\
0.01500 \\
0.01291\end{array}$ & $\begin{array}{l}6.60 \\
6.55 \\
6.72 \\
6.41\end{array}$ & $\begin{array}{l}1.348 \\
1.363 \\
1.387 \\
1.401\end{array}$ & $\begin{array}{l}F \\
F \\
F \\
S\end{array}$ \\
\hline $\begin{array}{r}8 \\
9 \\
10\end{array}$ & 100 & $\begin{array}{l}0.01009 \\
0.01343 \\
0.01172\end{array}$ & $\begin{array}{l}6.14 \\
6.54 \\
6.37\end{array}$ & $\begin{array}{l}1.831^{a} \\
1.703^{a} \\
1.825^{a}\end{array}$ & $\begin{array}{l}\text { S } \\
\text { F } \\
\text { F }\end{array}$ \\
\hline
\end{tabular}

a Width/depth $<5$. 
Table 4.9

CSU Phase II, Test Results for $\mathrm{d}_{85} / \mathrm{d}_{15}=4.6$, Thickness $=2 \mathrm{~d}_{50}=1 \mathrm{~d}_{100}$ '

$\mathrm{d}_{50}=1 \mathrm{in} \cdot \mathrm{\gamma}_{\mathrm{s}}=166 \mathrm{pcf}$

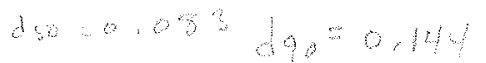

\begin{tabular}{lccccc}
\hline $\begin{array}{c}\text { Run } \\
\text { No. }\end{array}$ & $\begin{array}{c}\text { Nominal } \\
\text { Discharge } \\
\text { cfs }\end{array}$ & $\begin{array}{c}\text { Flume } \\
\text { Slope }\end{array}$ & $\begin{array}{c}\text { Average } \\
\text { Velocity } \\
\text { fps }\end{array}$ & $\begin{array}{c}\text { Average } \\
\text { Depth } \\
\text { ft }\end{array}$ & $\begin{array}{c}\text { Stable (S) or } \\
\text { Failed (F) }\end{array}$ \\
\cline { 2 - 3 } 1 & 25 & 0.00348 & 2.952 & 1.047 & $\mathrm{~S}$ \\
3 & 25 & 0.00451 & 3.027 & 0.978 & $\mathrm{~S}$ \\
4 & 25 & 0.00562 & 3.427 & 0.848 & $\mathrm{~F}$ \\
5 & 25 & 0.00451 & 3.373 & 0.926 & $\mathrm{~F}$ \\
6 & 50 & 0.00249 & 3.568 & $1.689^{\mathrm{a}}$ & $\mathrm{F}$ \\
7 & 50 & 0.00310 & 3.653 & 1.581 & $\mathrm{~F}$ \\
8 & 50 & 0.00249 & 3.880 & $1.660^{\mathrm{a}}$ & $\mathrm{F}$ \\
10 & 75 & 0.00176 & 3.922 & $2.561^{\mathrm{a}}$ & $\mathrm{F}$ \\
11 & 75 & 0.00219 & 4.119 & $2.416^{\mathrm{a}}$ & $\mathrm{F}$ \\
12 & 75 & 0.00265 & 4.360 & $2.284^{\mathrm{a}}$ & $\mathrm{F}$ \\
13 & 75 & 0.00219 & 4.056 & $2.478^{\mathrm{a}}$ & $\mathrm{F}$ \\
14 & 75 & 0.00176 & 3.796 & $2.442^{\mathrm{a}}$ & $\mathrm{S}$ \\
15 & 100 & 0.00106 & 3.710 & $3.310^{\mathrm{a}}$ & $\mathrm{F}$
\end{tabular}

a Width/depth<5. 
Table 4.10

CSU Phase II,

Test Results for $\mathrm{d}_{85} / \mathrm{d}_{15}=2.1$, Thickness $=2 \mathrm{~d}_{50}=1.4 \mathrm{~d}_{100}$,

$d_{50}=1$ in., $\gamma_{s}=167$ pcf, Shape Characteristics

Not Meeting Corps Guidance

$0.053 \mathrm{ds}$

$b_{0,0}=0,106$

\begin{tabular}{|c|c|c|c|c|c|}
\hline $\begin{array}{l}\text { Run } \\
\text { No. }\end{array}$ & $\begin{array}{c}\text { Nominal } \\
\text { Discharge } \\
\text { cfs }\end{array}$ & $\begin{array}{l}\text { Flume } \\
\text { Slope }\end{array}$ & $\begin{array}{l}\text { Average } \\
\text { Velocity } \\
\text { fps } \\
\end{array}$ & $\begin{array}{c}\text { Average } \\
\text { Depth } \\
\mathrm{ft}\end{array}$ & $\begin{array}{l}\text { Stable (S) or } \\
\text { Failed (F) }\end{array}$ \\
\hline 1 & 25 & 0.00367 & 2.57 & 1.273 & $S$ \\
\hline 2 & 25 & 0.00490 & 3.55 & 0.906 & $\mathrm{~S}$ \\
\hline 3 & 25 & 0.00617 & 3.87 & 0.846 & $\mathrm{~S}$ \\
\hline 4 & 25 & 0.00749 & 4.22 & 0.745 & S \\
\hline 5 & 25 & 0.00872 & 4.45 & 0.714 & $\mathrm{~F}$ \\
\hline 6 & 25 & 0.01012 & 4.59 & 0.689 & F \\
\hline 7 & 25 & 0.00869 & 4.77 & 0.714 & S \\
\hline 28 & 50 & 0.00409 & 3.85 & 1.386 & S \\
\hline 29 & 50 & 0.00490 & 4.30 & 1.262 & S \\
\hline 30 & 50 & 0.00561 & 4.76 & 1.252 & $\mathrm{~F}$ \\
\hline 31 & 50 & 0.00561 & 5.06 & 1.262 & S \\
\hline 20 & 75 & 0.00284 & 5.03 & $2.018^{a}$ & $\mathrm{~S}$ \\
\hline 21 & 75 & 0.00333 & 5.14 & $1.886^{a}$ & S \\
\hline 22 & 75 & 0.00407 & 4.64 & $1.802^{a}$ & $\mathrm{~F}$ \\
\hline 23 & 75 & 0.00343 & 5.02 & $1.885^{\mathrm{a}}$ & $\mathrm{S}$ \\
\hline 24 & 100 & 0.00225 & 4.86 & $2.479^{a}$ & $S$ \\
\hline 25 & 100 & 0.00266 & 4.62 & $2.397^{a}$ & S \\
\hline 26 & 100 & 0.00308 & 5.15 & $2.286^{\mathrm{a}}$ & $F$ \\
\hline 27 & 100 & 0.00318 & 5.06 & $2.337^{\mathrm{a}}$ & F \\
\hline
\end{tabular}

a. Width/depth $<5$. 
Table 4.11

WES Tilting Flume, Phase II

\begin{tabular}{|c|c|c|c|c|}
\hline $\begin{array}{l}\text { Bottom } \\
\text { Slope } \\
\mathrm{ft} / \mathrm{ft}\end{array}$ & $\begin{array}{l}\text { Average } \\
\text { Velocity } \\
\mathrm{ft} / \mathrm{sec} \\
\end{array}$ & $\begin{array}{l}\text { Average } \\
\text { Depth, ft } \\
\end{array}$ & $\mathrm{d}_{50} / \mathrm{ft}$ & $\mathrm{d}_{90} / \mathrm{ft}$ \\
\hline 0.00100 & 1.62 & $0.707^{a}$ & 0.036 & 0.055 \\
\hline 0.00200 & 1.90 & $0.647^{a}$ & 0.036 & 0.055 \\
\hline 0.00300 & 2.34 & 0.592 & 0.036 & 0.055 \\
\hline 0.00400 & 2.52 & 0.547 & 0.036 & 0.055 \\
\hline 0.00500 & 2.75 & 0.517 & 0.036 & 0.055 \\
\hline 0.00600 & 2.98 & 0.497 & 0.036 & 0.055 \\
\hline 0.00700 & 3.06 & 0.477 & 0.036 & 0.055 \\
\hline 0.00900 & 3.23 & 0.427 & 0.036 & 0.055 \\
\hline
\end{tabular}

NOTE: These resistance tests were conducted using riprap with one-third (by weight) $3 / 4-1 / 2 \mathrm{in}$, one-third $1 / 2-3 / 8 \mathrm{in.}$, and one-third $3 / 8 \mathrm{in},-\#_{4}$. The stone had thickness of $1 d_{100}$. Velocity was based on the average of two vertical profiles taken at the flume center line. Stabllity was not studied in these tests.

a Width/depth $<5$. 
Table 4.12

WES Tilting Flume, Phase III

\begin{tabular}{|c|c|c|c|c|}
\hline $\begin{array}{l}\text { Bottom } \\
\text { Slope } \\
\mathrm{ft} / \mathrm{ft}\end{array}$ & $\begin{array}{c}\text { Average } \\
\text { Velocity, } \\
\mathrm{ft} / \mathrm{sec} \\
\end{array}$ & $\begin{array}{c}\text { Average } \\
\text { Depth, ft }\end{array}$ & $\mathrm{d}_{50} / \mathrm{ft}$ & $\mathrm{d}_{90} / \mathrm{ft}$ \\
\hline 0.00300 & 1.94 & 0.346 & 0.036 & 0.055 \\
\hline 0.00400 & 2.09 & 0.320 & 0.036 & 0.055 \\
\hline 0.00500 & 2.26 & 0.296 & 0.036 & 0.055 \\
\hline 0.00600 & 2.38 & 0.279 & 0.036 & 0.055 \\
\hline 0.00700 & 2.99 & 0.407 & 0.036 & 0.055 \\
\hline 0.01600 & 2.72 & 0.207 & 0.036 & 0.055 \\
\hline 0.00200 & 2.10 & 0.582 & 0.036 & 0.055 \\
\hline 0.00250 & 2.37 & 0.538 & 0.036 & 0.055 \\
\hline 0.00300 & 2.48 & 0.511 & 0.036 & 0.055 \\
\hline 0.00350 & 2.60 & 0.490 & 0.036 & 0.055 \\
\hline 0.00400 & 2.69 & 0.466 & 0.036 & 0.055 \\
\hline 0.00200 & 1.73 & 0.423 & 0.036 & 0.055 \\
\hline 0.00300 & 1.96 & 0.369 & 0.036 & 0.055 \\
\hline 0.00400 & 2.16 & 0.338 & 0.036 & 0.055 \\
\hline 0.00500 & 2.28 & 0.314 & 0.036 & 0.055 \\
\hline 0.00600 & 2.40 & 0.298 & 0.036 & 0.055 \\
\hline 0.00200 & 2.06 & $0.624^{b}$ & 0.036 & 0.055 \\
\hline 0.00250 & 2.16 & 0.585 & 0.036 & 0.055 \\
\hline 0.00300 & 2.33 & 0.548 & 0.036 & 0.055 \\
\hline 0.00350 & 2.54 & 0.513 & 0.036 & 0.055 \\
\hline 0.00300 & 1.81 & 0.353 & 0.051 & 0.076 \\
\hline 0.00400 & 2.07 & 0.323 & 0.051 & 0.076 \\
\hline 0.00500 & 2.26 & 0.298 & 0.051 & 0.076 \\
\hline 0.00600 & 2.42 & 0.287 & 0.051 & 0.076 \\
\hline 0.00200 & 2.12 & 0.580 & 0.051 & 0.076 \\
\hline 0.00300 & 2.30 & 0.531 & 0.051 & 0.076 \\
\hline 0.00400 & 2.55 & 0.488 & 0.051 & 0.076 \\
\hline 0.00500 & 2.76 & 0.446 & 0.051 & 0.076 \\
\hline 0.01300 & 3.50 & 0.379 & 0.051 & 0.076 \\
\hline 0.01200 & 3.70 & 0.425 & 0.051 & 0.076 \\
\hline
\end{tabular}

NOTE: These resistance tests were conducted with stone having a thickness equal to $1 \mathrm{~d}$. Velocity was based on the average of four vertical velocity profiles. Stability was not studied in these tests.
a Gradation used for $\mathrm{d}_{50}=0.036 \mathrm{ft}$ was same as WES Phase II tests. Gradation used for $d_{50}=0.051 \mathrm{ft}$ was one-third $3 / 4-1$ in., one-third $1 / 2-3 / 4$ in. 5 and one-third $3 / 8-1 / 2$ in.
Width/depth $<5$. 
Table 4.13

Side Slope Versus Critical Bottom Velocity

\begin{tabular}{|c|c|}
\hline Slope & $\begin{array}{l}\text { Critical Bottom } \\
\text { Velocity, Et/sec }\end{array}$ \\
\hline Horlzontal & $\begin{array}{l}2.64 \\
2.58 \\
2.53\end{array}$ \\
\hline $1 \mathrm{~V}: 4 \mathrm{H}$ & $\begin{array}{l}2.63 \\
2.58 \\
2.63\end{array}$ \\
\hline $1 \mathrm{~V}: 2.75 \mathrm{H}$ & $\begin{array}{l}2.51 \\
2.58 \\
2.61 \\
2.61\end{array}$ \\
\hline $1 \mathrm{~V}: 2 \mathrm{H}$ & $\begin{array}{l}2.41 \\
2.44 \\
2.41 \\
2.46\end{array}$ \\
\hline $1 \mathrm{~V}: 1.5 \mathrm{H}$ & $\begin{array}{l}2.15 \\
2.20\end{array}$ \\
\hline $1 \mathrm{~V}: 1.25 \mathrm{H}$ & $\begin{array}{l}2.06 \\
2.06 \\
1.87 \\
1.94 \\
1.91 \\
2.00\end{array}$ \\
\hline
\end{tabular}


Table 4.14

Angle of Repose

\begin{tabular}{|c|c|c|c|c|c|c|}
\hline $\begin{array}{c}\text { Pressure } \\
\text { Fluctuations } \\
\end{array}$ & Submerged & $\begin{array}{c}\text { Revetment } \\
\text { Thickness } \\
\mathrm{d}_{100}\end{array}$ & $\begin{array}{l}\text { Revetmen } \\
\text { Height } \\
\frac{\mathrm{L}_{\mathrm{S}}}{\mathrm{d}_{50}}\end{array}$ & Surface & $\begin{array}{l}\text { No. of } \\
\text { Tests } \\
\end{array}$ & $\begin{array}{c}\text { Average } \\
\text { Angle of } \\
\text { Repose } \\
\text { deg }\end{array}$ \\
\hline No & No & 1.0 & 10.4 & Sand & 14 & 52.3 \\
\hline No & Yes & 1.0 & 10.4 & Sand & 14 & 52.8 \\
\hline Yes & Yes & 1.0 & 10.4 & Sand & 21 & 53.5 \\
\hline Yes & Yes & 1.0 & 10.4 & Smooth & 10 & 54.3 \\
\hline Yes & Yes & 1.0 & 20.8 & Sand & 9 & 47.5 \\
\hline Yes & Yes & 1.0 & 20.8 & Smooth & 9 & 50.5 \\
\hline Yes & Yes & 1.0 & 41.7 & Sand & 8 & 42.3 \\
\hline Yes & Yes & 1.0 & 41.7 & Smooth & 9 & 42.5 \\
\hline Yes & Yes & 1.5 & 41.7 & Smooth & 12 & 46.3 \\
\hline Yes & Yes & 2.0 & 41.7 & Smooth & 7 & 48.8 \\
\hline
\end{tabular}


Table 4.15

\section{Analysis of Dorena Dam Prototype Data}

1V:2H Side Slope, Straight Channel

\begin{tabular}{|c|c|c|c|c|c|c|c|c|c|c|}
\hline Test & $\begin{array}{l}\text { Sta } \\
\text { tion }\end{array}$ & $\begin{array}{l}\text { Right } \\
\text { or } \\
\text { Left } \\
\text { Bank } \\
\end{array}$ & $\begin{array}{l}\text { Grada- } \\
\text { tion }^{a} \\
\end{array}$ & $\begin{array}{l}\text { Esti- } \\
\text { mated } \\
\text { V Over } \\
\text { Toe } \\
\end{array}$ & $\begin{array}{l}\text { Depth } \\
\text { Over } \\
\text { Toe } \\
\end{array}$ & $\frac{\gamma_{w}}{\gamma_{s}-\gamma_{w}}$ & $-1^{1 / 2}$ & $\frac{V}{\sqrt{g D}}$ & $\frac{\mathrm{d}_{30}}{\mathrm{D}}$ & $\begin{array}{c}\text { Failed } \\
\text { or } \\
\text { Stable }\end{array}$ \\
\hline 3 & $2+80$ & $\mathrm{~L}$ & A & 7.1 & 7.3 & & 0.34 & & 0.067 & $S$ \\
\hline 3 & $2+80$ & $\mathrm{R}$ & B & 7.1 & 7.3 & & 0.34 & & 0.084 & $\mathrm{~S}$ \\
\hline 3 & $3+46$ & $\mathrm{~L}$ & A & 11.5 & 6.6 & & 0.58 & & 0.074 & S \\
\hline 3 & $3+46$ & $\mathrm{R}$ & $B$ & 10.5 & 6.6 & & 0.53 & & 0.092 & S \\
\hline 3 & $3+90$ & $\mathrm{~L}$ & $\mathrm{C}$ & 14.5 & 6.0 & & 0.77 & & 0.095 & $F$ \\
\hline 3 & $3+90$ & $\mathrm{R}$ & D & 14.5 & 6.0 & & 0.77 & & 0.120 & $\mathrm{~S}$ \\
\hline 3 & $4+12$ & $\mathrm{~L}$ & C & 13.0 & 6.7 & & 0.65 & & 0.085 & $S$ \\
\hline 3 & $4+12$ & $\mathbf{R}$ & D & 13.0 & 6.7 & & 0.65 & & 0.107 & $\mathrm{~S}$ \\
\hline 3 & $4+75$ & $L \& R$ & D & 15.0 & 6.3 & & 0.77 & & 0.114 & $\mathrm{~F}$ \\
\hline 4 & $3+46$ & $\mathrm{~L}$ & A & 10.9 & 6.6 & & 0.55 & & 0.074 & $S$ \\
\hline 4 & $3+46$ & $\mathrm{R}$ & B & 10.9 & 6.6 & & 0.55 & & 0.092 & S \\
\hline 4 & $4+12$ & $\mathrm{~L}$ & C & 13.0 & 6.7 & & 0.65 & & 0.085 & S \\
\hline 4 & $4+12$ & $\mathrm{R}$ & D & 13.0 & 6.7 & & 0.65 & & 0.107 & S \\
\hline
\end{tabular}

Rock Characteristics:

\begin{tabular}{|c|c|c|c|}
\hline Gradation & $\begin{array}{r}\mathrm{d}_{30} \\
\mathrm{Et} \\
\end{array}$ & $\begin{array}{c}\mathrm{d}_{100} \\
\mathrm{ft}\end{array}$ & $\frac{\text { Thickness }}{\mathrm{d}_{100}}$ \\
\hline$A$ & 0.49 & 1.08 & 1.08 \\
\hline B & 0.61 & 1.28 & 1.02 \\
\hline C & 0.57 & $?$ & $?$ \\
\hline D & 0.72 & 1.79 & 1.12 \\
\hline
\end{tabular}


Table 4.16

CSU Phase IV

Test Results for $\mathrm{d}_{85} / \mathrm{d}_{15}=2.3$, Thickness $=1.3 \mathrm{~d}_{100}, \mathrm{~d}_{50}=1 \mathrm{in.}$,

$\gamma_{s}=167$ pcf, Shape Characteristics Not Meeting

Corps Criteria

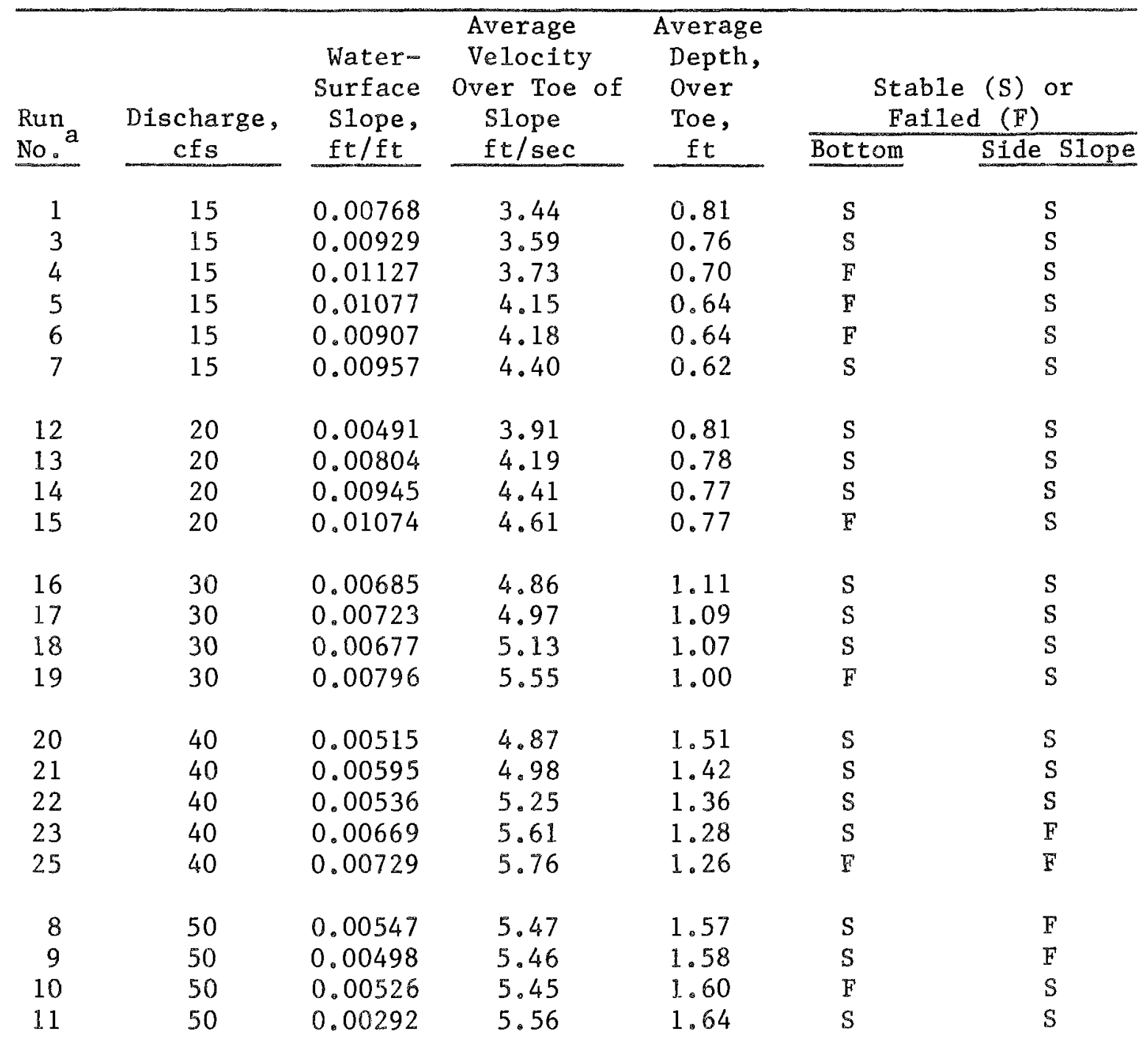

(Continued)

a Test numbers omitted did not have velocities measured over toe. 
Table 4.16 (Concluded)

\begin{tabular}{|c|c|c|c|c|c|c|c|}
\hline \multirow{2}{*}{$\begin{array}{l}\text { Run } \\
\text { No. } \\
\end{array}$} & \multirow{2}{*}{$\begin{array}{c}\text { Discharge, } \\
\text { cfs } \\
\end{array}$} & \multirow{2}{*}{$\begin{array}{c}\text { Water- } \\
\text { Surface } \\
\text { Slope, } \\
\mathrm{ft} / \mathrm{ft}\end{array}$} & \multirow{2}{*}{$\begin{array}{l}\text { Average } \\
\text { Velocity } \\
\text { Over Toe of } \\
\text { Slope } \\
\mathrm{ft} / \mathrm{sec} \\
\end{array}$} & \multirow{2}{*}{$\begin{array}{c}\text { Average } \\
\text { Depth, } \\
\text { Over } \\
\text { Toe, } \\
\text { ft }\end{array}$} & \multicolumn{3}{|c|}{$\begin{array}{l}\text { Stable (S) or } \\
\text { Failed (F) }\end{array}$} \\
\hline & & & & & Bottom & Side & Slope \\
\hline 29 & 50 & 0.00451 & 5.77 & 1.61 & $-\infty-b$ & 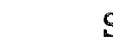 & 5 \\
\hline 30 & 50 & 0.00449 & 5.89 & 1.50 & $--b$ & 1 & $\mathrm{~F}$ \\
\hline 31 & 40 & 0.00560 & 5.71 & 1.28 & $-\infty b$ & I & $\mathrm{F}$ \\
\hline 33 & 20 & 0.00921 & 4.15 & 0.81 & $--b$ & 5 & $S$ \\
\hline 34 & 20 & 0.01112 & 4.64 & 0.76 & $-\infty b$ & $S$ & $S$ \\
\hline 35 & 20 & 0.01310 & 4.77 & 0.74 & $--b$ & 1 & $\mathrm{~F}$ \\
\hline
\end{tabular}

b Test numbers omitted did not have velocities measured over toe. Bottom fixed with wire mesh to ensure side slope fallure. 
Table 4.17

CSU Phase IV

Test Results for $d_{85} / d_{15}=2.3$, Thickness $=1 d_{100}, d_{50}=1$ in.s

$\gamma_{s}=167$ pcf, Shape Characceristics Not Meeting

Corps Criteria

\begin{tabular}{|c|c|c|c|c|c|c|c|}
\hline \multirow{2}{*}{$\begin{array}{l}\text { Run } \\
\text { No. }\end{array}$} & \multirow{2}{*}{$\begin{array}{c}\text { Discharge, } \\
\text { cfs } \\
\end{array}$} & \multirow{2}{*}{$\begin{array}{c}\text { Water } \\
\text { Surface } \\
\text { Slope, } \\
\mathrm{ft} / \mathrm{ft} \\
\end{array}$} & $\begin{array}{l}\text { Average } \\
\text { Velocity } \\
\text { Over Toe of } \\
\text { Slope }\end{array}$ & \multirow{2}{*}{$\begin{array}{c}\text { Average } \\
\text { Depth } \\
\text { Over } \\
\text { Toe, } \\
\text { ft } \\
\end{array}$} & \multicolumn{3}{|c|}{$\begin{array}{c}\text { Stable (S) or } \\
\text { Failed (F) }\end{array}$} \\
\hline & & & $\mathrm{ft} / \mathrm{sec}^{\mathrm{a}}$ & & Bottom & Side & Slope \\
\hline 36 & 15 & $--\infty b$ & 3.54 & 0.76 & S & & S \\
\hline 37 & 15 & 0.01002 & 3.73 & 0.68 & S & & $S$ \\
\hline 38 & 15 & 0.01165 & 3.91 & 0.64 & $F$ & & $S$ \\
\hline 39 & 15 & 0.01090 & 4.03 & 0.69 & S & & S \\
\hline 40 & 20 & 0.00900 & 4.42 & 0.80 & F & & S \\
\hline 41 & 20 & 0.00832 & 4.26 & 0.84 & $S$ & & $S$ \\
\hline 42 & 30 & 0.00711 & 4.97 & 1.09 & F & & $\mathrm{F}$ \\
\hline 43 & 30 & 0.00482 & 4.56 & 1.20 & $\mathrm{~s}$ & & S \\
\hline 44 & 30 & 0.00649 & 4.68 & 1.16 & F & & $F^{c}$ \\
\hline 45 & 40 & 0.00464 & 4.93 & 1.45 & $\mathrm{~F}$ & $\mathrm{~S}$ & S \\
\hline 46 & 40 & 0.00408 & 4.62 & 1.54 & $\mathrm{~S}$ & & $S$ \\
\hline 47 & 50 & 0.00287 & 4.93 & 1.77 & S & & $s_{c}$ \\
\hline 48 & 50 & 0.00434 & 5.27 & 1.63 & $\mathrm{~F}$ & & $F^{c}$ \\
\hline 49 & 50 & $-\infty b$ & 5.36 & 1.63 & S & $\mathrm{F}$ & $\mathrm{F}$ \\
\hline 50 & 50 & $-\infty-b$ & 5.46 & 1.61 & $\mathrm{~F}$ & $E$ & F \\
\hline
\end{tabular}

a Estimated from results given in Table 4.16.

Not determined.

c Failed area less than $0.1 \mathrm{ft}^{2}$. 
Table 4.18

CSU Phase IV

Test Results for $d_{85} / d_{15}=2.0$, Thickness $=1 d_{100}, d_{50}=0.5$ in.,

$\gamma_{\mathrm{S}}=167$ pcf, Shape Characteristics Not Meeting

Corps Criteria

\begin{tabular}{|c|c|c|c|c|c|c|c|}
\hline \multirow{2}{*}{$\begin{array}{l}\text { Run } \\
\text { No }\end{array}$} & \multirow{2}{*}{$\begin{array}{c}\text { Discharge, } \\
\text { cfs }\end{array}$} & \multirow{2}{*}{$\begin{array}{l}\text { Water- } \\
\text { Surface } \\
\text { Slope, } \\
\text { ft/ft }\end{array}$} & $\begin{array}{l}\text { Average } \\
\text { Velocity } \\
\text { Over Toe of } \\
\text { Slope }\end{array}$ & \multirow{2}{*}{$\begin{array}{l}\text { Average } \\
\text { Depth } \\
\text { Over } \\
\text { Toe, } \\
\text { ft }\end{array}$} & \multicolumn{3}{|c|}{$\begin{array}{l}\text { Stable (S) or } \\
\text { Failed (F) }\end{array}$} \\
\hline & & & $\mathrm{ft} / \mathrm{sec}$ & & Bottom & Side & Slope \\
\hline 1 & 15 & 0.00203 & 2.15 & 1.02 & S & & S \\
\hline 2 & 15 & 0.00269 & 2.31 & 0.93 & $S$ & & $\mathrm{~S}$ \\
\hline 3 & 15 & 0.00207 & 2.39 & 0.91 & $F$ & & S \\
\hline 5 & 15 & 0.00197 & 2.87 & 0.91 & $\mathrm{~S}$ & & $S_{0}$ \\
\hline 21 & 15 & 0.00375 & 2.50 & 0.97 & S & & $\mathrm{F}^{\mathrm{a}}$ \\
\hline 15 & 20 & 0.00295 & 3.24 & 1.07 & $S$ & & S \\
\hline 16 & 20 & 0.00400 & 3.46 & 1.00 & F & & $F$ \\
\hline 17 & 20 & 0.00347 & 3.25 & 1.03 & S & & $S$ \\
\hline 10 & 30 & 0.00242 & 3.51 & 1.54 & $S$ & & $S$ \\
\hline 11 & 30 & 0.00234 & 3.75 & 1.48 & S & & $S$ \\
\hline 12 & 30 & 0.00221 & 3.55 & 1.57 & S & & $F$ \\
\hline 13 & 30 & 0.00206 & 3.73 & 1.43 & S & & $\mathrm{S}$ \\
\hline 14 & 30 & 0.00322 & 3.83 & 1.39 & $\mathrm{~F}$ & & $\mathrm{~F}$ \\
\hline 23 & 30 & 0.00270 & 4.27 & 1.29 & $F$ & & $\mathrm{~F}$ \\
\hline 18 & 35 & 0.00240 & 3.88 & 1.68 & $\mathrm{~s}$ & & $\mathrm{~F}$ \\
\hline 19 & 35 & 0.00250 & 4.08 & 1.62 & $S$ & & $F$ \\
\hline 6 & 40 & 0.00241 & 4.38 & 1.62 & $\mathrm{~F}$ & & $F$ \\
\hline 7 & 40 & 0.00170 & 4.28 & 1.65 & $\mathrm{~F}$ & & $\mathrm{~F}$ \\
\hline 8 & 40 & 0.00268 & 4.10 & 1.70 & $\mathrm{~F}$ & & $F$ \\
\hline 9 & 40 & 0.00159 & 3.63 & 1.88 & $S$ & & $S$ \\
\hline 22 & 40 & 0.00158 & 2.93 & 2.17 & S & & $\mathrm{S}$ \\
\hline
\end{tabular}

a Failed area less than $0.10 \mathrm{ft}^{2}$ 
Table 4.19

Test Results From WES Curved Channel Model

\begin{tabular}{|c|c|c|c|c|}
\hline $\begin{array}{c}\text { Discharge } \\
\text { cfs } \\
\end{array}$ & $\begin{array}{c}\text { Average Velocity } \\
\text { Over Toe of } \\
\text { Slope } \\
\mathrm{ft} / \mathrm{sec}^{\mathrm{a}} \\
\end{array}$ & $\begin{array}{l}\text { Average Depth } \\
\text { Over } \\
\text { Toe, } \\
\text { ft } \\
\end{array}$ & $\begin{array}{l}\text { Stable (S) or } \\
\text { Failed (F) }\end{array}$ & $\begin{array}{l}\text { Number } \\
\text { of } 6- \\
\text { Hour } \\
\text { Runs } \\
\end{array}$ \\
\hline 7.0 & 2.44 & 0.47 & $\mathrm{~S}$ & 10 \\
\hline 8.0 & 2.57 & 0.50 & $F$ & 1 \\
\hline 9.0 & 2.62 & 0.56 & $\mathrm{~F}$ & 3 \\
\hline
\end{tabular}

a For stable runs this was the maximum average velocity in the vertical over the toe. For failure, run velocity was measured at the location of the failure. Fallure points and maximum velocities were always between stations 70 and 75 . 
Table 4.20

Prototype Dara

(From Blodget and McConaughy (1986))

\begin{tabular}{|c|c|c|c|c|c|c|c|c|}
\hline $\begin{array}{l}\text { Measurenent } \\
\text { Number } \\
\end{array}$ & $\begin{array}{r}d_{30} \\
f t \\
\end{array}$ & $\frac{\mathrm{d}_{30}}{\mathrm{D}_{\max }}$ & $\frac{d_{85}}{d_{15}}$ & $\begin{array}{l}V_{\max }, \\
\mathrm{Et} / \mathrm{sec}\end{array}$ & $\frac{\gamma_{w}}{\gamma_{S}-\gamma_{w}}$ & ${ }^{1 / 2} \frac{v_{\max }}{\sqrt{\mathrm{gD}_{\max }}}$ & $\begin{array}{c}\text { Stable (S) } \\
\text { or } \\
\text { Failure (E) }\end{array}$ & $\cot$ \\
\hline 2 & 0.54 & 0.011 & 2.0 & 6.17 & & 0.119 & S & 1.9 \\
\hline 5 & 0.55 & 0.045 & 2.5 & 8.17 & & 0.320 & S & 1.8 \\
\hline 6 & 0.55 & 0.033 & 2.5 & 7.97 & & 0.266 & $\mathrm{~F}$ & 1.8 \\
\hline 7 & 0.55 & 0.032 & 2.5 & $9.33^{a}$ & & 0.300 & F & 1.8 \\
\hline 8 & 0.46 & 0.063 & 2.7 & $11.75^{a}$ & & 0.564 & $F$ & 2.0 \\
\hline 9 & 1.75 & 0.273 & $-a$ & $16.22^{2}$ & & 0.842 & S & 2.1 \\
\hline 10 & 0.42 & 0.075 & 3.0 & 7.43 & & 0.412 & $\mathrm{~s}$ & 2.1 \\
\hline 14 & 0.52 & 0.042 & $-\infty$ & $6.46^{a}$ & & 0.243 & $\$$ & 2.1 \\
\hline 15 & 0.52 & 0.054 & $-w_{b}$ & 9.46 & & 0.402 & $\mathrm{~s}$ & 2.1 \\
\hline 22 & 0.63 & 0.052 & $-b$ & $15.90^{a}$ & & 0.611 & S & 2.0 \\
\hline 25 & 0.63 & 0.066 & c.nom & $27.24^{2}$ & & 1.205 & $F$ & 1.9 \\
\hline 27 & 1.12 & 0.052 & 1.6 & 5.2 & & 0.153 & $s$ & 2.0 \\
\hline 28 & 1.12 & 0.039 & 1.6 & 22.34 & & 0.569 & $\mathrm{~s}$ & 2.0 \\
\hline 33 & 1.05 & 0.086 & 2.8 & $19.05^{\mathrm{a}}$ & & 0.713 & s & 2.0 \\
\hline 34 & 1.05 & 0.162 & 2.8 & $15.30^{a}$ & & 0.784 & S & 2.0 \\
\hline 37 & 0.38 & 0.019 & 2.1 & 8.54 & & 0.264 & $\mathrm{~s}$ & 1.8 \\
\hline 38 & 0.38 & 0.012 & 2.1 & $11.17^{\mathrm{a}}$ & & 0.278 & $F$ & 1.8 \\
\hline 39 & 0.38 & 0.029 & 2.1 & $10.25^{2}$ & & 0.397 & $F$ & 1.8 \\
\hline
\end{tabular}

a Estmated using Equation 4.28 .

Not given. 
Table 4.21

Gradations for Riprap P1acement in the Dry,

Low-Turbulence Zones

\begin{tabular}{|c|c|c|c|c|c|c|c|}
\hline \multirow{3}{*}{$\begin{array}{c}\text { Riprap } \\
\text { Thickness, in. }\end{array}$} & \multicolumn{6}{|c|}{ Limits of Stone Weight, $1 b^{a}$} & \multirow{3}{*}{$\mathrm{d}_{30}(\mathrm{~min})$} \\
\hline & \multicolumn{2}{|c|}{100} & \multicolumn{2}{|c|}{50} & \multicolumn{2}{|c|}{15} & \\
\hline & Max & Min & $\operatorname{Max}$ & Min & $\operatorname{Max}$ & Min & \\
\hline \multicolumn{8}{|c|}{ Specific Weight $=155$ pcf } \\
\hline 12 & 81 & 32 & 24 & 16 & 12 & 5 & 0.48 \\
\hline 15 & 159 & 63 & 47 & 32 & 23 & 10 & 0.61 \\
\hline 18 & 274 & 110 & 81 & 55 & 41 & 17 & 0.73 \\
\hline 21 & 435 & 174 & 129 & 87 & 64 & 27 & 0.85 \\
\hline 24 & 649 & 260 & 192 & 130 & 96 & 41 & 0.97 \\
\hline 27 & 924 & 370 & 274 & 185 & 137 & 58 & 1.10 \\
\hline 30 & 1,268 & 507 & 376 & 254 & 188 & 79 & 1.22 \\
\hline 33 & 1,688 & 675 & 500 & 338 & 250 & 105 & 1.34 \\
\hline 36 & 2,191 & 877 & 649 & 438 & 325 & 137 & 1.46 \\
\hline 42 & 3,480 & 1,392 & 1,031 & 696 & 516 & 217 & 1.70 \\
\hline 48 & 5,194 & 2,078 & 1,539 & 1,039 & 769 & 325 & 1.95 \\
\hline 54 & 7,396 & 2,958 & 2,191 & 1,479 & 1,096 & 462 & 2.19 \\
\hline
\end{tabular}

Specific Weight $=165$ pcf

$\begin{array}{rrrrrrrr}12 & 86 & 35 & 26 & 17 & 13 & 5 & 0.48 \\ 15 & 169 & 67 & 50 & 34 & 25 & 11 & 0.61 \\ 18 & 292 & 117 & 86 & 58 & 43 & 18 & 0.73 \\ 21 & 463 & 185 & 137 & 93 & 69 & 29 & 0.85 \\ 24 & 691 & 276 & 205 & 138 & 102 & 43 & 0.97 \\ 27 & 984 & 394 & 292 & 197 & 146 & 62 & 1.10 \\ 30 & 1,350 & 540 & 400 & 270 & 200 & 84 & 1.22 \\ 33 & 1,797 & 719 & 532 & 359 & 266 & 112 & 1.34 \\ 36 & 2,331 & 933 & 691 & 467 & 346 & 146 & 1.46 \\ 42 & 3,704 & 1,482 & 1,098 & 741 & 549 & 232 & 1.70 \\ 48 & 5,529 & 2,212 & 1,638 & 1,106 & 819 & 346 & 1.95 \\ 54 & 7,873 & 3,149 & 2,335 & 1,575 & 1,168 & 492 & 2.19\end{array}$

Specific Weight $=175$ pcf

$\begin{array}{rrrrrrrr}12 & 92 & 37 & 27 & 18 & 14 & 5 & 0.48 \\ 15 & 179 & 72 & 53 & 36 & 27 & 11 & 0.61 \\ 18 & 309 & 124 & 92 & 62 & 46 & 19 & 0.73 \\ 21 & 491 & 196 & 146 & 98 & 73 & 31 & 0.85 \\ 24 & 733 & 293 & 217 & 147 & 109 & 46 & 0.97\end{array}$

(Continued)

a Stone welght limit data from OCE 1971. 
Table 4.21 (Concluded)

\begin{tabular}{|c|c|c|c|c|c|c|c|}
\hline \multirow{4}{*}{$\begin{array}{c}\text { Riprap } \\
\text { Thickness, in. }\end{array}$} & \multirow{2}{*}{\multicolumn{6}{|c|}{$\frac{\text { Limits of Stone Weight, } \text { Ib }^{a}}{\text { Percent Lighter by Weight }}$}} & \multirow{4}{*}{$\mathrm{d}_{30}^{(\mathrm{min})}$} \\
\hline & & Perce & Ligh & by $W$ & ght & & \\
\hline & \multicolumn{2}{|c|}{100} & \multicolumn{2}{|c|}{50} & \multicolumn{2}{|c|}{15} & \\
\hline & Max & Min & Max & Min & $\operatorname{Max}$ & Min & \\
\hline \multicolumn{8}{|c|}{ Specific Weight $=175$ pct } \\
\hline 27 & 1,044 & 417 & 309 & 209 & 155 & 65 & 1.10 \\
\hline 30 & 1,432 & 573 & 424 & 286 & 212 & 89 & 1.22 \\
\hline 33 & 1.906 & 762 & 565 & 381. & 282 & 119 & 1.34 \\
\hline 36 & 2,474 & 990 & 733 & 495 & 367 & 155 & 1.46 \\
\hline 42 & 3,929 & 1,571 & 1,164 & 786 & 582 & 246 & 1.70 \\
\hline 48 & 5,864 & 2,346 & 1,738 & 1,173 & 869 & 367 & 1.95 \\
\hline 54 & 8,350 & 3,340 & 2.474 & 1.670 & 1,237 & 522 & 2.19 \\
\hline
\end{tabular}




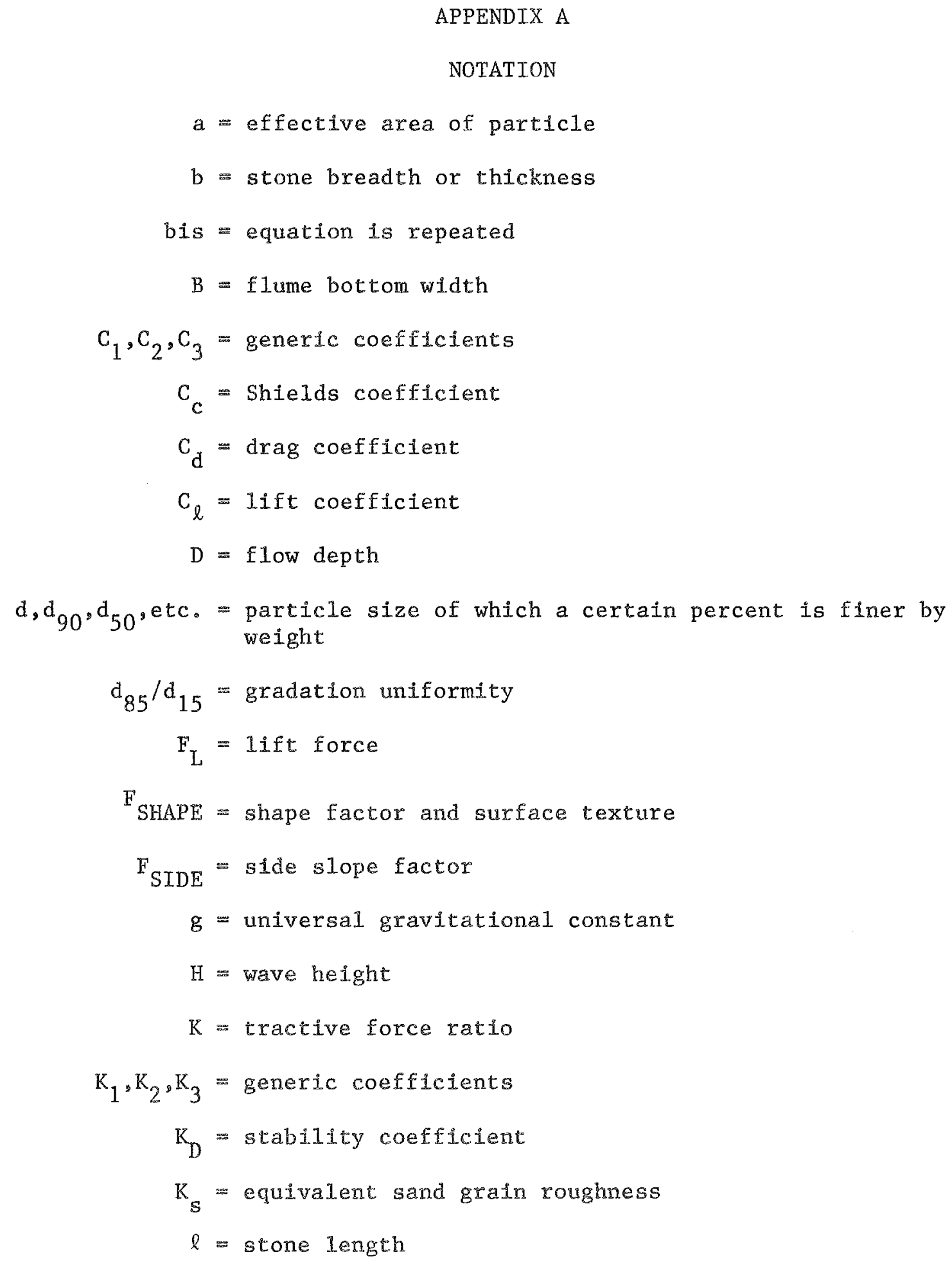




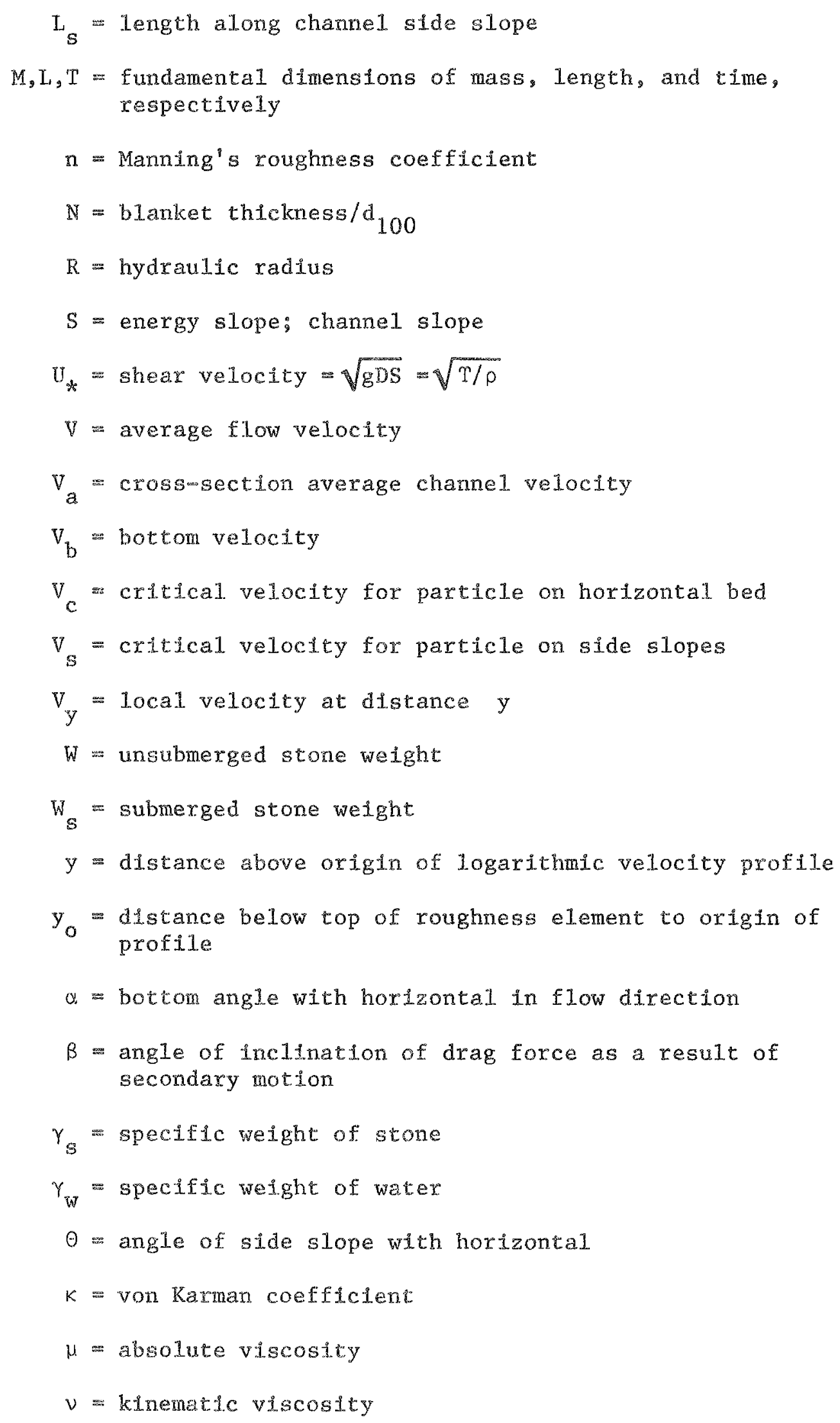




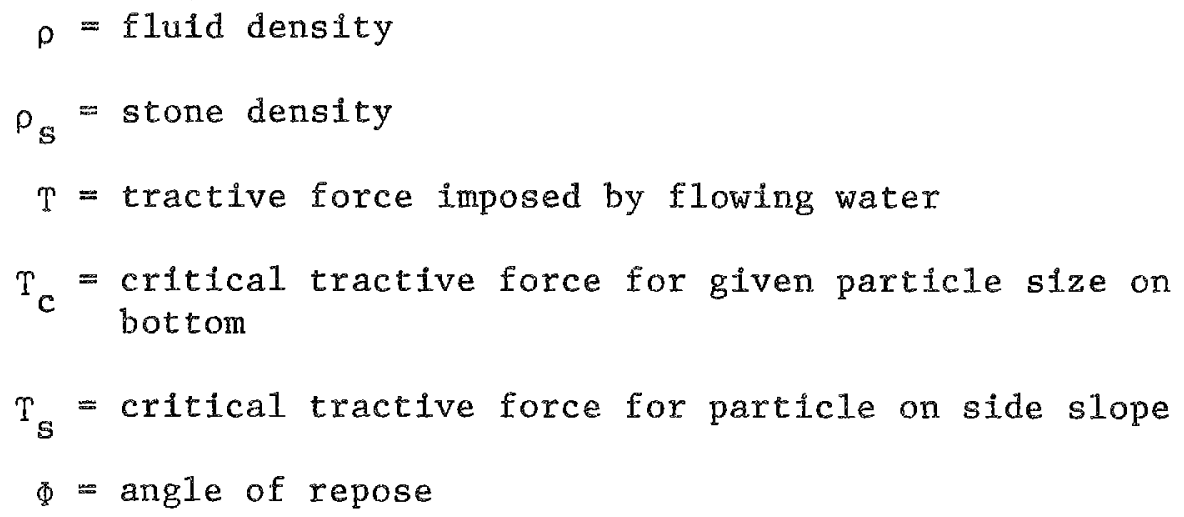
$T_{c}=\underset{c r i t i c a l}{\text { bottom }}$ tractive force for given particle size on

$T_{\mathbf{S}}=$ critical tractive force for particle on side slope 